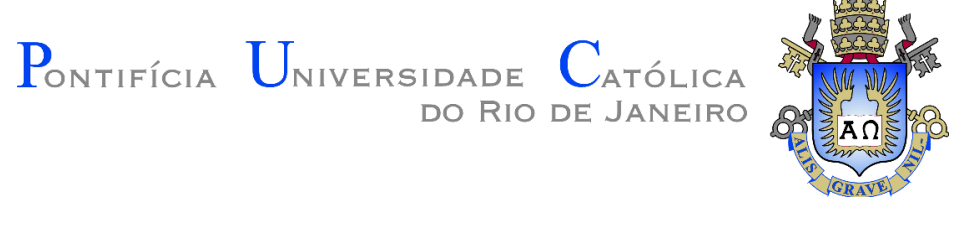

Vitor Cataldo Andrade de Medeiros

\title{
Liquefação hidrotérmica da biomassa de bagaço de malte para a produção de bio-óleo e biocarvão
}

Dissertação apresentada ao programa de Pós-graduação em Engenharia de Materiais e de Processos Químicos e Metalúrgicos da PUC-Rio como requisito parcial para obtenção do grau de Mestre em Engenharia de Materiais e de Processos Químicos e Metalúrgicos.

Orientador: Prof. Francisco José Moura 
Todos os direitos reservados. É proibida a reprodução total ou parcial do trabalho sem autorização da universidade, do autor e do orientador.

\section{Vitor Cataldo Andrade de Medeiros}

Graduou-se em Engenharia Química pela Pontifícia Universidade Católica do Rio de Janeiro (Rio de Janeiro, Brasil).

Ficha Catalográfica

Medeiros, Vitor Cataldo Andrade de

Liquefação hidrotérmica da biomassa de bagaço de malte para a produção de bio-óleo e biocarvão / Vitor Cataldo Andrade de Medeiros ; orientador: Francisco José Moura. - 2019.

80 f. : il. color. ; $30 \mathrm{~cm}$

Dissertação (mestrado)-Pontifícia Universidade Católica do Rio de Janeiro, Departamento de Engenharia Química e de Materiais, 2019. Inclui bibliografia

1. Engenharia Química e de Materiais - Teses. 2. Biomassa. 3. Bagaço de malte. 4. Caracterização. 5. Liquefação hidrotérmica. 6. Biocombustíveis. I. Moura, Francisco José. II. Pontifícia Universidade Católica do Rio de Janeiro. Departamento de Engenharia Química e de Materiais. III. Título. 


\section{Agradecimentos}

A Deus, por me iluminar e me guiar sempre para traçar os melhores caminhos.

Aos meus pais Claudia e Vanderlei, pelo amor, carinho, paciência e ensinamentos ao longo da vida e meu irmão Fabio, pela amizade, alegrias e surpresas inesperadas, como a adoção da Pan.

A todos da minha família, por saber que sempre terei todo apoio e incentivo em qualquer trajetória seguida.

À minha namorada Ana, que está sempre ao meu lado e com a qual amo compartilhar todos os momentos da vida.

Aos amigos feitos ao longo da vida, pelas histórias, conversas, viagens, saídas, risadas, cervejas e por tornar todos os momentos memoráveis.

Ao meu orientador Professor Francisco José Moura, pela orientação, ensinamentos e confiança na realização deste trabalho.

À minha co-orientadora Flávia de Miranda Gonçalves, por toda ajuda e momentos de descontração, tornando os dias de trabalho mais divertidos.

Aos colegas que ajudaram no desenvolvimento deste mestrado, Eliane e IC, os professores Rodrigo e Rogério, os técnicos de laboratório, Henrique, Victor e Álvaro, e a todos os demais amigos feitos ao longo de oito anos na PUC-Rio.

A todo suporte da PUC-Rio, de pesquisadores a funcionários, sem o qual este trabalho não poderia ter sido realizado.

À ajuda externa da Firjan e do CETEM na realização de experimentos, elevando a qualidade deste estudo.

À Fundação de Amparo à Pesquisa do Estado do Rio de Janeiro, FAPERJ, pelo apoio financeiro no projeto realizado.

À todos aqueles que não foram citados aqui, mas que contribuíram de alguma forma ao longo deste caminho. 


\section{Resumo}

Cataldo Andrade de Medeiros, Vitor; Moura, Francisco José. Li quefação hidrotérmica da biomassa de bagaço de malte para a produção de bio-óleo e biocarvão. Rio de Janeiro, 2019. 80p. Dissertação de Mestrado - Departamento de Engenharia Química e de Materiais, Pontifícia Universidade Católica do Rio de Janeiro.

A necessidade mundial de energia tem aumentado exponencialmente, no entanto, as reservas de combustíveis fósseis, além de produzirem sérios impactos ambientais, estão se esgotando ao longo dos anos. Por estas razões, muitos estudos vêm sendo feitos na busca de novas fontes renováveis de energia, como o reaproveitamento de resíduos de biomassa. Desta forma, o objetivo deste trabalho é estudar o processo de liquefação hidrotérmica (HTL) do bagaço de malte, gerado ao final do processo cervejeiro, para a produção de bio-óleo e biocarvão como potenciais combustíveis renováveis. A caracterização inicial da biomassa apresentou significativa quantidade de celulose e hemicelulose, alto teor de umidade e pequeno tamanho de partícula, sendo ideal para o processo. A HTL foi conduzida em um reator sob alta pressão em diferentes faixas de temperatura e tempos de residência. Uma modelagem cinética e termodinâmica foi realizada para a etapa inicial da liquefação, apresentando 62,08 kJ.mol ${ }^{-1}$ de energia de ativação e caráter endotérmico. Bio-óleo apresentou melhor rendimento, $18,2 \%$, a $300{ }^{\circ} \mathrm{C}$ e $30 \mathrm{~min}$, já o biocarvão atingiu $21,0 \%$ de rendimento a $250{ }^{\circ} \mathrm{C}$ e $5 \mathrm{~min}$. A pequena diferença de valores, ao longo do tempo, comprovou que a maior produtividade ocorre sempre em $5 \mathrm{~min}$, sendo este o tempo ótimo de reação. A análise do poder calorífico superior (PCS) demonstrou que altas temperaturas elevam a energia produzida. Em 5 min e a $300{ }^{\circ} \mathrm{C}$, melhores condições de operação, a HTL gerou um bio-óleo com PCS de 33,6 MJ. $\mathrm{kg}^{-1}$, sendo 27,8\% inferior a gasolina e um biocarvão com 26,7 MJ.kg-1, sendo 11,4\% superior ao carvão tradicional. Através das caracterizações finais, foi possível observar alta degradação da estrutura lignocelulósica da biomassa e identificar os compostos presentes no bio-óleo, indicando que os produtos da HTL apresentam alto potencial de utilização como combustíveis renováveis.

\section{Palavras-chave}

Biomassa; Bagaço de malte; Caracterização; Liquefação hidrotérmica; Biocombustíveis; Poder calorífico. 


\section{Abstract}

Cataldo Andrade de Medeiros, Vitor; Moura, Francisco José (Advisor). Hydrothermal liquefaction of malt bagasse biomass for bio-oil and biochar production. Rio de Janeiro, 2019. 80p. Dissertação de mestrado - Departamento de Engenharia Química e de Materiais, Pontifícia Universidade Católica do Rio de Janeiro.

The global energy needs have increased exponentially; however, fossil fuel reserves, in addition to producing serious environmental impacts, are running out over the years. For these reasons, many studies have been done in the search for new renewable energy sources, such as the reuse of biomass wastes. In this way, the purposes of this study are associated with the hydrothermal liquefaction process (HTL) of the malt bagasse, generated at the end of the brewing process, for the production of bio-oil and biochar as potential renewable fuels. The initial biomass characterization presented a significant amount of cellulose and hemicellulose, high moisture content and small particle size, ideal for the process. The HTL was conducted in a high pressure reactor in different temperature ranges and residence times. A kinetic and thermodynamic modeling was performed for the initial stage of liquefaction, presenting $62.08 \mathrm{~kJ} \mathrm{~mol}^{-1}$ of activation energy and endothermic behavior. Bio-oil presented a better yield, $18.2 \%$, at $300{ }^{\circ} \mathrm{C}$ and $30 \mathrm{~min}$, while the biochar reached $21.0 \%$ yield at $250{ }^{\circ} \mathrm{C}$ and $5 \mathrm{~min}$. The small distintion between values, over time, proved that the highest productivity always occurs at $5 \mathrm{~min}$, which is the optimal reaction time. The higher heating value analysis (HHV) showed that high temperatures increase the energy produced. At $5 \mathrm{~min}$ and $300{ }^{\circ} \mathrm{C}$, better operating conditions, HTL generated a bio-oil with $\mathrm{HHV}$ of $33.6 \mathrm{MJ} . \mathrm{kg}^{-1}$, with $27.8 \%$ less than gasoline and a biochar with $26.7 \mathrm{MJ} . \mathrm{kg}^{-1}$, being $11.4 \%$ higher than traditional coal. Through the final characterization, it was possible to observe high degradation of the lignocellulosic structure of the biomass and to identify the compounds present in the bio-oil, indicating that the HTL products present high potential for use as renewable fuels.

\section{Keywords}

Biomass; Malt bagasse; Characterization; Hydrothermal liquefaction; Biofuels; Heating value. 


\section{Sumário}

1 Introdução 11

2 Objetivos $\quad 13$

2.1 Objetivo Geral 13

$\begin{array}{lll}2.2 & \text { Objetivo Específico } & 13\end{array}$

3 Revisão Bibliográfica $\quad 14$

3.1 Cenário energético 14

3.2 Biomassa 14

$\begin{array}{ll}3.2 .1 \text { Celulose } & 16\end{array}$

$\begin{array}{ll}3.2 .2 \text { Hemicelulose } & 17\end{array}$

$\begin{array}{ll}3.2 .3 \text { Lignina } & 17\end{array}$

$\begin{array}{lll}3.2 .4 & \text { Extrativos orgânicos } & 18\end{array}$

3.2.5 Componentes inorgânicos 19

$\begin{array}{lll}3.3 & \text { Reaproveitamento de resíduos } & 19\end{array}$

3.3.1 Produção cervejeira 19

3.3.2 Bagaço de malte 22

3.4 Processos de conversão da biomassa 23

3.4.1 Liquefação hidrotérmica 24

$\begin{array}{lll}3.4 .2 & \text { Produtos gerados } & 29\end{array}$

4 Materiais e Métodos $\quad 31$

4.1 Biomassa de bagaço de malte 31

4.2 Caracterização do bagaço de malte 32

4.2.1 Teor de umidade $\quad 32$

4.2.2 Análise granulométrica 32

$\begin{array}{ll}\text { 4.2.3 Densidade e porosidade } & 32\end{array}$

$\begin{array}{lll}\text { 4.2.4 Composição da biomassa } & 33\end{array}$

4.3 Processo de liquefação hidrotérmica 33

4.3.1 Modelagem cinética de liquefação 35

4.3.2 Termodinâmica via Teoria do Estado de Transição 37

$\begin{array}{ll}\text { 4.3.3 Rendimento e produtividade } & 40\end{array}$

4.4 Caracterização da biomassa e dos produtos gerados 41

4.4.1 Poder calorífico superior $\quad 41$

4.4.2 Análise imediata $\quad 42$

4.4.3 Análise elementar 42

4.4.4 Espectroscopia no Infravermelho 42

$\begin{array}{lll}4.4 .5 & \text { Termogravimetria } & 43\end{array}$

4.4.6 Microscopia Eletrônica de Varredura 43

4.4.7 Cromatografia gasosa 44

$5 \quad$ Resultados e Discussões $\quad 45$

5.1 Caracterização do bagaço de malte 45

5.1.1 Teor de umidade $\quad 45$ 
5.1.2 Análise granulométrica 45

$\begin{array}{lll}\text { 5.1.3 Densidade e porosidade } & 46\end{array}$

5.1.4 Composição da biomassa 46

5.2 Liquefação hidrotérmica 47

5.2.1 Modelagem cinética 47

5.2.2 Termodinâmica via Teoria do Estado de Transição 51

5.2.3 Rendimento e produtividade 52

5.3 Comparação da biomassa e dos produtos gerados 57

$\begin{array}{lll}\text { 5.3.1 Poder calorífico superior } & 57\end{array}$

5.3.2 Análise imediata 60

5.3.3 Análise elementar 61

5.3.4 Espectroscopia no Infravermelho 62

5.3.5 Termogravimetria 63

5.3.6 Microscopia Eletrônica de Varredura 65

$\begin{array}{lll}\text { 5.3.7 Cromatografia gasosa } & 67\end{array}$

$\begin{array}{lll}6 & \text { Conclusões } & \mathbf{7 0}\end{array}$

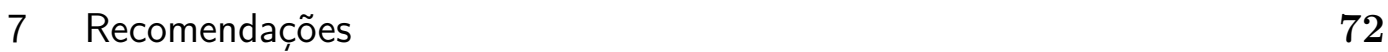

$\begin{array}{ll}\text { Referências bibliográficas } & 73\end{array}$ 


\section{Lista de figuras}

Figura 3.1 Estrutura da biomassa lignocelulósica [21] 16

$\begin{array}{lll}\text { Figura 3.2 } & \text { Estrutura da celulose [23] } & 16\end{array}$

Figura 3.3 Monossacarídeos presentes na hemicelulose [20] 17

$\begin{array}{lll}\text { Figura 3.4 Estrutura da lignina [20] } & 18\end{array}$

Figura 3.5 Fluxograma do processo genérico de produção de cerveja, adaptado de [31] 20

Figura 3.6 Principais processos de conversão da biomassa, adaptado de [19] 23

Figura 3.7 Influência da temperatura na formação de produtos [43] 26

$\begin{array}{lll}\text { Figura 4.1 Bagaço de malte } & 31\end{array}$

Figura 4.2 Processo HTL em operação 34

Figura 4.3 Diagrama de blocos do processo de HTL 35

Figura 5.1 Análise granulométrica 45

Figura 5.2 Efeito da temperatura na razão de liquefação 47

Figura 5.3 Relação entre a taxa de liquefação e o conteúdo residual 48

Figura 5.4 Equação de Arrhenius linearizada 49

Figura 5.5 Rendimento e produtividade a $250{ }^{\circ} \mathrm{C}$

Figura 5.6 Rendimento e produtividade a $275{ }^{\circ} \mathrm{C} \quad 54$

Figura 5.7 Rendimento e produtividade a $300{ }^{\circ} \mathrm{C} \quad 54$

Figura 5.8 Produtos gerados na HTL: 1. produtos solúveis em água, 2. biocarvão, 3. bio-óleo 56

Figura 5.9 Poder calorífico superior dos produtos da HTL 58

Figura 5.10 Espectroscopia no Infravermelho da biomassa e do biocarvão 62

Figura 5.11 Termogravimetria da biomassa e do biocarvão. a: porcentagem mássica; b: derivada mássica

Figura 5.12 Visão da biomassa no MEV. a: visão geral com ampliação de 60x; b: particulados com apliação de 500x; c,d: partículas com ampliação de 1000x

Figura 5.13 Visão do biocarvão no MEV. a: visão geral com apliação de 30x; b: partículas com ampliação de 150x; c: estruturas com ampliação de 500x; d: micro estruturas com ampliação de 1500x

Figura 5.14 Cromatografia gasosa do bio-óleo 


\section{Lista de tabelas}

Tabela 3.1 Comparação dos principais processos de conversão termoquímica, adaptado de [19] 24

Tabela 3.2 Influência das variáveis no processo de HTL 28

$\begin{array}{lll}\text { Tabela 5.1 Densidade e porosidade } & 46\end{array}$

Tabela 5.2 Composição da biomassa 46

Tabela 5.3 Variáveis cinéticas do processo em diferentes temperaturas 48

Tabela 5.4 Parâmetros cinéticos da reação de liquefação 49

Tabela 5.5 Comparação de resultados da modelagem cinética 50

Tabela 5.6 Parâmetros termodinâmicos $\quad 51$

Tabela 5.7 Comparação dos resultados termodinâmicos 52

Tabela 5.8 Tempos de processo (min) 56

Tabela 5.9 Poder calorífico superior de diferentes biomassas $\quad 57$

Tabela 5.10 Comparação do PCS do biocarvão 59

Tabela 5.11 Comparação do PCS do bio-óleo 59

Tabela 5.12 Análise imediata da biomassa e do biocarvão 60

Tabela 5.13 Análise elementar da biomassa e do biocarvão $\quad 61$

Tabela 5.14 Principais compostos identificados por CG 68 


\section{Lista de Abreviaturas}

CG - Cromatografia gasosa

CHNS - Carbono, hidrogênio, nitrogênio e enxofre

CETEM - Centro de Tecnologia Mineral

EBC - European Brewery Convention

EDS - Energy Dispersive System

EPE - Empresa de Pesquisa Energética

FTIR - Espectroscopia no infravermelho por transformada de Fourier

HTL - Liquefação hidrotérmica - Hydrothermal liquefaction

IEA - International Energy Agency

MAPA - Ministério da Agricultura, Pecuária e Abastecimento

MEV - Microscopia Eletrônica de Varredura

OECD - Organization for Economic Cooperation and Development

IPCC - Intergovernmental Panel on Climate Change

PCS - Poder calorífico superior

psa - Produtos solúveis em água

TCD - Detector de condutividade térmica

TG - Termogravimetria 


\section{Introdução}

Atualmente grande parte do consumo energético mundial provém de combustíveis fósseis, gerando aumento de gases do efeito estufa, poluição, aquecimento global, entre outras mudanças climáticas estudadas pelo Intergovernmental Panel on Climate Change (IPCC) [1]. O cenário futuro apresenta níveis crescentes na demanda global de energia.

Estima-se que a expansão econômica, principalmente de países em desenvolvimento que não fazem parte da Organization for Economic Cooperation and Development (OECD), irá gerar um aumento de $48 \%$ do total de energia consumida no mundo para as próximas três décadas [2]. Dessa forma, pesquisas e estudos sobre novas fontes de energia renovável tem sido feitos, visando torná-las cada vez mais competitivas e acessíveis frente as fontes não renováveis. Assim, calcula-se que nos próximos anos haverá um crescimento na utilização de fontes renováveis com média de $2,6 \%$ ao ano no total de energia utilizada $[2,3]$.

Acompanhando essas rápidas mudanças do atual cenário energético mundial, o Brasil tem cada vez mais um papel de destaque, sendo até mesmo um dos líderes em processos de reaproveitamento de resíduos e efluentes industriais para a geração de energia limpa e renovável [4]. Dentre todos os resíduos existentes, destaca-se a biomassa vegetal, composta principalmente por celulose, hemicelulose e lignina, sendo a única fonte renovável de carbono com alto potencial energético que pode ser convertida em produtos sólidos, líquidos ou gasosos dependendo do processo na qual é submetida $[5,6]$.

O Brasil consolida-se como o segundo maior produtor mundial de etanol, fazendo da cana-de-açúcar sua principal fonte de biomassa. No entanto, um novo mercado em expansão vem ganhando força nos últimos anos, o mercado cervejeiro. Segundo recente levantamento do Ministério da Agricultura, Pecuária e Abastecimento (MAPA), o número de cervejarias no país cresceu $750 \%$ na última década e continua em expansão [7], fazendo o Brasil alcançar a terceira posição entre os maiores produtores mundiais de cerveja com aproximadamente 13,8 bilhões de L por ano [8].

Atrelado a esse expressivo crescimento está a formação de resíduos da produção cervejeira, principalmente a biomassa de bagaço de malte, no qual é 
gerada de 14 a $20 \mathrm{~kg}$ para cada $100 \mathrm{~L}$ de cerveja produzida, alcançando uma média anual de cerca de 2,4 bilhões de kg no caso brasileiro [9]. Além disso, essa biomassa apresenta uma demanda química de oxigênio cerca de cem vezes maior que a do esgoto doméstico para ser degradada, necessitando de uma destinação ambiental adequada [10].

Dessa forma, a elevada produção de bagaço de malte torna-se atrativa, do ponto de vista energético, quando considerados processos de termoconversão. No entanto, a maioria desses processos deparam-se com uma das principais características desse tipo de biomassa: o alto teor de umidade ao final do processo cervejeiro, alcançando valores superiores a $80 \%$ de umidade total [11].

O elevado teor de umidade presente em algumas biomassas apresenta um efeito negativo em processos térmicos, visto que necessita de um elevado custo energético para sua vaporização. Desta forma, a liquefação hidrotérmica (HTL) surge como uma alternativa interessante, pois utiliza a água presente na biomassa para a reação. Os fluidos atingem propriedades adequadas para liquefação, como alta densidade, elevado calor e capacidade de transferência de massa, rápida decomposição e extração [12]. Além disso, a alta pressão da HTL faz a água permanecer em estado líquido, onde atua como reagente e catalisador, promovendo reações de hidrólise, fragmentação e polimerização da biomassa, dependendo da faixa de temperatura do processo, gerando assim, uma elevada conversão em subprodutos de alto potencial energético como o bio-óleo e biocarvão [13].

Visando ampliar a utilização de recursos renováveis, em especial grandes resíduos industriais brasileiros, o presente trabalho busca estudar os aspectos relacionados ao processo de HTL do bagaço de malte bem como caracterizar a matéria-prima e os produtos gerados. 


\section{Objetivos}

\section{1}

\section{Objetivo Geral}

Tendo em vista a crescente expansão do mercado cervejeiro brasileiro, assim como sua alta geração de resíduos, o objetivo deste trabalho foi estudar o processo de liquefação hidrotérmica do bagaço de malte, conduzido em um reator batelada a alta temperatura e pressão, para a produção de bio-óleo e biocarvão como potenciais combustíveis renováveis.

\section{2}

\section{Objetivo Específico}

- Caracterização física e química do bagaço de malte gerado na produção cervejeira.

- Analisar as variáveis do processo de HTL (temperatura e tempo de residência) visando maior rendimento e produtividade de bio-óleo e biocarvão.

- Estudar o perfil cinético e termodinâmico da reação de liquefação.

- Caracterização física e química do biocarvão e bio-óleo produzidos para comparação com a biomassa inicial buscando melhorias em termos energéticos. 


\section{3 \\ Revisão Bibliográfica}

\section{1}

\section{Cenário energético}

O consumo energético mundial está relacionado ao aumento populacional, desenvolvimento de mercado e expansão econômica. Segundo o último levantamento da International Energy Agency (IEA), relacionado ao ano de 2017, a demanda energética mundial teve um aumento de 2,1\%, principalmente impulsionada por países em expansão como China e Índia [14].

Nos três anos anteriores (2014 - 2016) constatou-se uma estagnação na emissão de gases do efeito estufa, sendo a primeira vez na história em que esta estagnação não estava relacionada a uma crise ou recessão global, já que neste período o crescimento da economia mundial foi cerca de $3 \%$. Entretanto, levantamentos recentes mostram que as emissões de combustíveis fósseis, principalmente de dióxido de carbono, voltaram a crescer, atingindo um novo recorde histórico, alcançando a marca de 32,5 gigatoneladas de $\mathrm{CO}_{2}$ por ano lançados na atmosfera [14]. No entanto este cenário pode ser alterado nos próximos anos.

Dentre todas as matérias-primas, as fontes de energia renovável foram as que obtiveram maior taxa de crescimento contribuindo com $25 \%$ da demanda energética mundial [14]. O Brasil ganha destaque neste caso. No último ano de levantamento da Empresa de Pesquisa Energética (EPE), 42,9\% de toda energia do país foi proveniente de fontes renováveis, em especial, a hidráulica e a derivada de biomassa como o etanol [15]. Assim, mais estudos e investimentos na reutilização de resíduos de biomassa podem contribuir para ampliar o campo de energia sustentável no país.

\section{2}

\section{Biomassa}

O termo biomassa é ainda pouco conhecido fora dos campos da energia e da ecologia, mas vem se difundindo cada vez mais na atualidade. Segundo a diretriz 2009/28/EC da União Européia, biomassa é definida como "a fração biodegradável de produtos, resíduos de origem biológica da agricultura 
(incluindo subtâncias vegetais e animais), silvicultura e indústrias relacionadas, incluindo pesca e aquicultura, bem como a fração biodegradável de resíduos industriais e urbanos" [16]. No campo energético, biomassa nada mais é do que a matéria orgânica de origem animal ou vegetal, produzida por processos biológicos, que pode ser utilizada como material combustível ou fonte de energia não poluente para produção de calor ou biocombustíveis. [17, 18].

Combustíveis fósseis são formados por processos naturais, como a decomposição de matéria orgânica, ao longo de milhões de anos. Como a taxa de consumo desses combustíveis é maior que a taxa de produção, estes são considerados recursos não-renováveis. No caso da biomassa vegetal, as plantas usam a luz solar através da fotossíntese para metabolizar dióxido de carbono atmosférico e crescer, além disso, os animais se desenvolvem ao se alimentarem de biomassa [19]. Dessa forma, ocorre uma alta taxa de renovação da biomassa, tornando-a um recurso renovável.

No que refere-se a biomassa animal como fonte de energia, esta apresenta um valor secundário. Os animais heterotróficos, alimentam-se diretamente ou indiretamente de matéria orgânica produzida por organismos autotróficos, em geral, seres vegetais. Assim, a energia presente na biomassa animal é sempre derivada de biomassa vegetal [18].

No cenário energético, a biomassa vegetal tem amplo destaque, pois fornece vantagens ambientais significativas em contraste com os combustíveis fósseis. Além do fato de ser uma fonte renovável, sua utilização como energia gera menos gases de efeito estufa se comparada a combustíveis fósseis, podendo assim ser considerada como neutra, uma vez que o $\mathrm{CO}_{2}$ emitido na queima dos combustíveis derivados da biomassa é reutilizado pelas plantas durante seu crescimento através da reação de fotossíntese. Entre as biomassas mais comuns destacam-se: bagaço de cana-de-açúcar, palha de milho, fibra de coco, serragem, madeira, entre outras [20].

A biomassa vegetal apresenta uma estrutura lignocelulósica, representada na Figura 3.1, e constitui a maior fonte de carboidratos naturais do mundo. Esse material é composto de fibras de celulose envolvidas em uma matriz amorfa de hemicelulose e lignina. Essa matriz amorfa age como uma barreira natural ao ataque de microrganismos e enzimas, tornando a matéria vegetal estruturalmente rígida e pouco reativa. A composição química da biomassa lignocelulósica é variável apresentando geralmente conteúdo entre 35-50\% de celulose, seguido de 20-35\% de hemicelulose, 10-25\% de lignina e uma pequena quantidade de cinzas e extrativos [21]. 


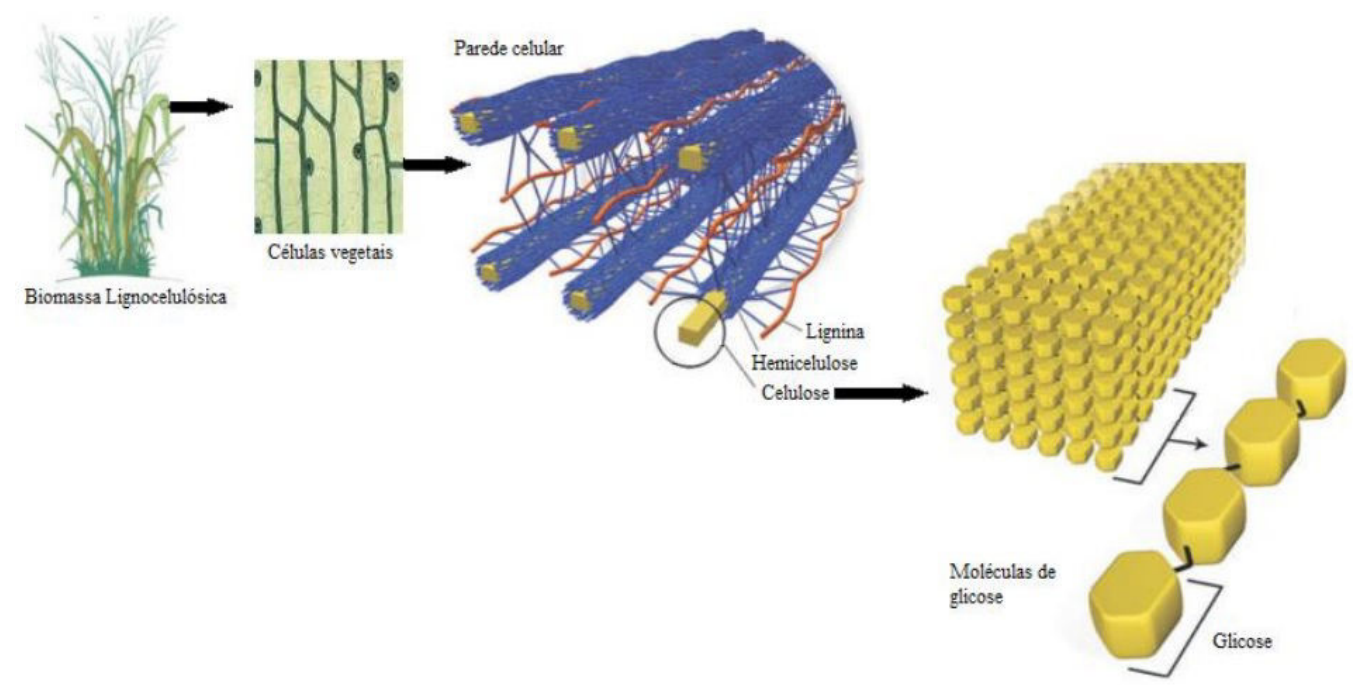

Figura 3.1: Estrutura da biomassa lignocelulósica [21]

\subsection{1}

\section{Celulose}

A celulose engloba isoladamente em torno de $40 \%$ de toda reserva de carbono disponível na biosfera, é a fonte mais abundante deste elemento base dos componentes orgânicos. Está presente em todas as plantas, desde árvores altamente desenvolvidas até organismos mais primitivos [22].

A estrutura deste polímero natural, representada na Figura 3.2 pode ser classificada em três níveis organizacionais. O primeiro é definido pela sequência de ligações covalentes do tipo $\beta$-D $(1 \rightarrow 4)$ glicosídicas de moléculas de $\beta$ glicose, formando uma estrutura de fórmula geral $\left(\mathrm{C}_{6} \mathrm{H}_{10} \mathrm{O}_{5}\right)_{n}$. O segundo nível descreve a conformação molecular, isto é, a organização espacial das unidades repetitivas, que é caracterizada pelas distâncias das ligações e respectivos ângulos e pelas ligações de hidrogênio intramoleculares. O terceiro nível define a associação das moléculas formando agregados com uma determinada estrutura cristalina. Os três níveis de estrutura agregados proporcionam à cadeia de celulose uma elevada massa molecular, resistência a tensão, considerável grau de cristalinidade, insolubilidade em água e estrutura rígida [21-23].

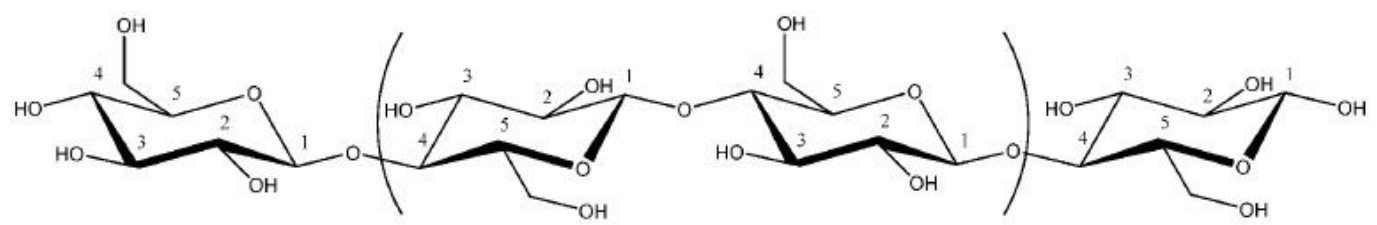

Figura 3.2: Estrutura da celulose [23] 


\subsection{2}

\section{Hemicelulose}

A hemicelulose é outro constituinte das paredes celulares de uma biomassa vegetal. Enquanto a celulose apresenta uma estrutura forte e cristalina resistente à hidrólise, a hemicelulose tem uma estrutura amorfa, aleatória e com pouca força de interação intermolecular, sendo facilmente hidrolisada por ácidos e bases diluídas. É um grupo de carboidratos com uma estrutura de cadeia ramificada e um menor grau de polimerização, sendo representado pela fórmula genérica $\left(\mathrm{C}_{5} \mathrm{H}_{8} \mathrm{O}_{4}\right)_{n}$ [24].

Existe uma variação significativa na composição e estrutura da hemicelulose entre diferentes biomassas. A maioria das hemiceluloses, no entanto, contém resíduos simples de açúcar como d-xilose (mais comum), d-glicose, d-galactose, l-ababinose, ácido d-glicurônico e d-manose, entre outros [19], representados na Figura 3.3.

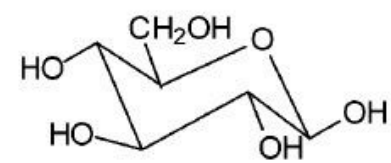

Glicose

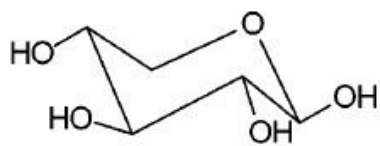

Xilose

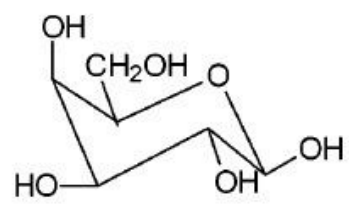

Galactose

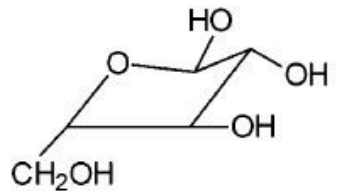

Arabinose

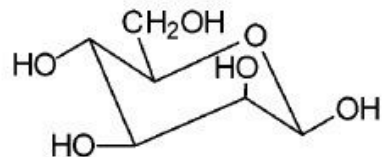

Manose

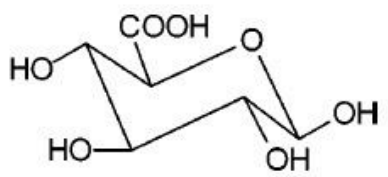

Ácido Glicurônico

Figura 3.3: Monossacarídeos presentes na hemicelulose [20]

\subsection{3}

\section{Lignina}

A lignina é um heteropolímero amorfo e sem estrutura exata que consiste em três diferentes unidades de fenilpropanos: álcool p-cumarílico, álcool coferílico e álcool sinapílico, ligados entre si de forma ramificada, apresentando assim, uma estrutura tridimensional complexa, possuindo regiões amorfas e estruturas globulares [21], como representado na Figura 3.4. Além disso, também pode-se encontrar ligações covalentes entre a sua estrutura e os polissacarídeos dos demais compostos, o que intensifica a união adesiva entre fibras de celulose e hemicelulose com a lignina, assim, sua principal função é atuar como ligante na aglomeração dos componentes celulósicos e fibrosos [25].

A composição e a organização dos constituintes da lignina variam de uma biomassa para outra, dependendo da matriz de celulose-hemicelulose. Em 
processos de hidrólise enzimática dos materiais lignocelulósicos, a lignina atua como uma barreira física para as enzimas que podem ficar retidas irreversivelmente na sua estrutura e, consequentemente, influenciar na quantidade de enzima requerida para a hidrólise, assim como dificultar a sua recuperação [21]. Já em processos térmicos, a decomposição da lignina pode gerar uma série de hidrocarbonetos aromáticos e de compostos fenólicos, de alta importância para indústria química [25].

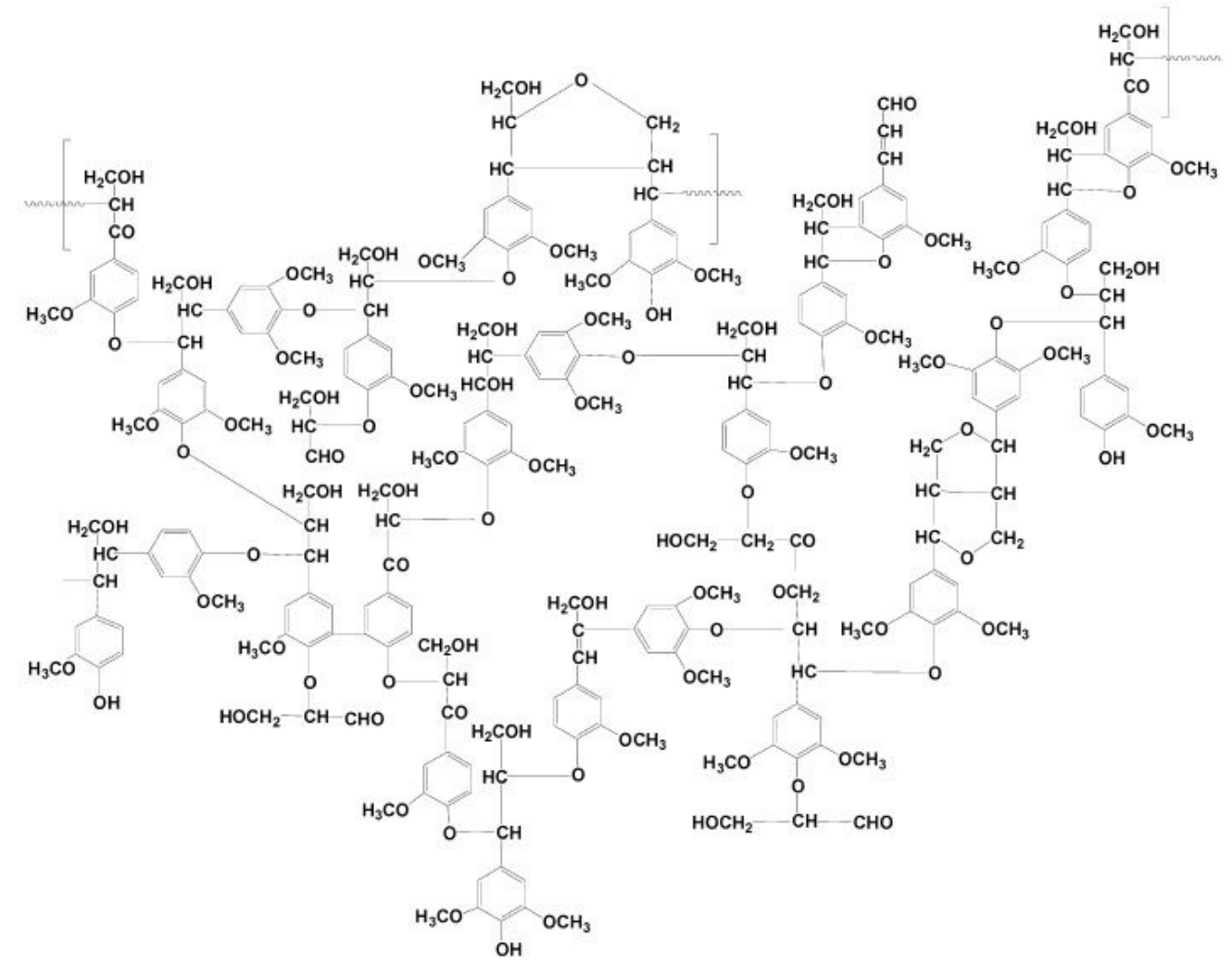

Figura 3.4: Estrutura da lignina [20]

\subsection{4}

\section{Extrativos orgânicos}

Os extrativos são componentes da biomassa que não fazem parte da parede celular das fibras, ou seja, não estruturais, e são compostos extracelulares de baixo peso molecular. Estes podem ser extraídos utilizando solventes polares como água, cloreto de metileno e álcool, ou através de solventes apolares como tolueno e hexano. Exemplos de extrativos incluem: gorduras, ceras, proteínas, compostos fenólicos, açúcares simples, pectinas, gomas, resinas, amidos, óleos essenciais, entre outros. Os extrativos funcionam como intermediários no metabolismo, como reserva energética e como defesa contra ataques microbianos e de insetos [20]. 


\section{2 .5}

\section{Componentes inorgânicos}

A biomassa possui pequenas quantidades de compostos minerais inorgânicos, conhecidos como cinzas, que correspondem a cerca de $1 \%$ da sua massa total. De forma geral, estes componentes estão associados aos compostos orgânicos, onde tem função fisiológica. Os mais comuns são o cálcio, magnésio, potássio e sódio, além de apresentar traços de metais como manganês, cobre, chumbo, níquel, zinco e vanádio [26].

\section{3}

\section{Reaproveitamento de resíduos}

As indústrias de fabricação e transformação de materiais presentes nos mais diversos setores do mercado, produzem, em maior ou menor grau, uma certa quantidade de resíduos que nem sempre são reaproveitados ou possuem um destino ecologicamente correto [27]. Isto ocorre principalmente devido ao aumento de gastos, falta de incentivos e estudo sobre o tema e carência de unidades adequadas e especializadas de tratamento [28].

Dar um destino correto aos resíduos constitui um grande desafio. Em alguns casos, estes subprodutos podem ser reutilizados após etapas de reciclagem ou destinados para processos como: digestão anaeróbia, compostagem, aterros sanitários e reaproveitamento energético [29].

\subsection{1 \\ Produção cervejeira}

Segundo a Legislação Brasileira, Decreto n⿳o 2314, de 04 de setembro de 1997, art.64: "cerveja é a bebida obtida pela fermentação alcoólica do mosto cervejeiro oriundo do malte de cevada e água potável, por ação da levedura, com adição de lúpulo" [30]. Por muitos séculos a produção cervejeira em escala artesanal era suficiente para suprir toda a demanda, produzindo-se cervejas de grande variedade e boa qualidade. Contudo, a grande difusão e aceitação da bebida ao longo de sua história a levaram a ser uma das bebidas mais apreciadas e consumidas nos cinco continentes, em países de diferentes climas e culturas [11].

Atualmente, a produção em larga escala para atender a grande demanda do produto caracteriza o mercado cervejeiro mundial, levando à geração de grandes quantidades de resíduos [11]. O processo de fabricação pode ser dividido em quatro principais etapas: maltaria, preparação do mosto, fermentação e envase, como pode ser observado na Figura 3.5. 


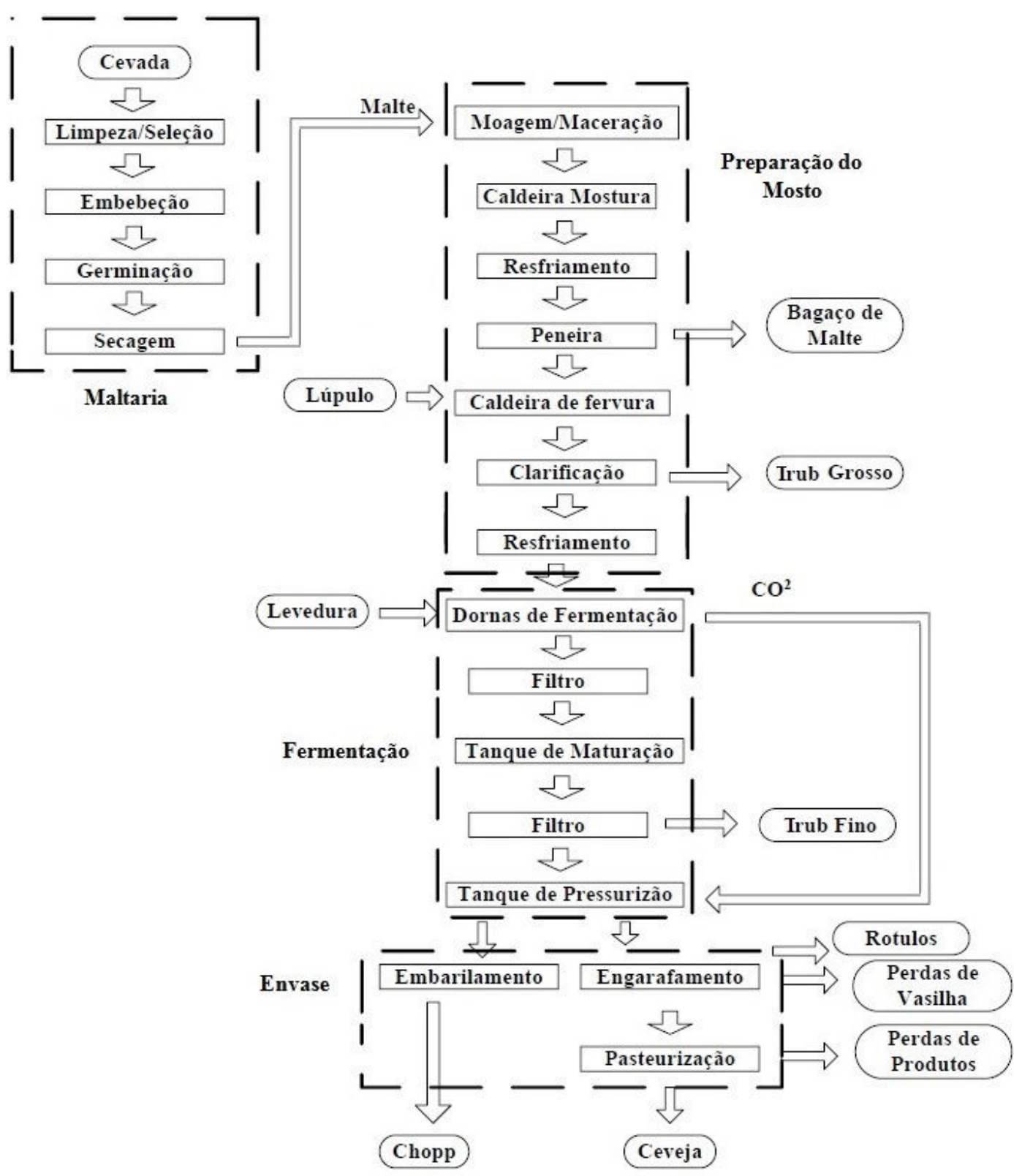

Figura 3.5: Fluxograma do processo genérico de produção de cerveja, adaptado de [31]

$\triangleright$ Maltaria:

As instalações denominadas maltarias, podem ou não ser anexas às empresas cervejeiras. Em geral, a cevada ou outros tipos de grãos são recebidos a granel da lavoura. Em um primeiro momento, são submetidos a um processo de limpeza para separação de impurezas seguida uma seleção granulométrica de modo a obter um malte homogêneo [9].

Os grãos ficam armazenado em silos onde recebem água até atingir um teor de umidade próximo a 45\%. Com o aumento da umidade, os grãos germinam, ou seja, saem de seu estado de latência, gerando um aumento no quociente respiratório, estimulando a atividade de enzimas 
que começam a converter as reservas de amido e proteínas em açúcares e aminoácidos, os quais serão utilizados no crescimento da planta $[32,33]$. Os grãos germinados são enviados para fornos de secagem, onde interrompe-se o processo de germinação pela ação do calor de vapor injetado e ocorre a caramelização dos grãos, transformando-os no malte [9].

$\triangleright$ Preparação do mosto

A produção de cerveja inicía-se com a moagem do malte para romper a casca dos grãos, proporcionando o acesso ao amido. Na caldeira de mostura o malte é adicionado à água em torno de $65{ }^{\circ} \mathrm{C}$, para reativar e acelerar a atividade enzimática, convertendo as proteínas em peptídeos e outros complexos orgânicos nitrogenados, e posteriormente em aminoácidos, fundamentais para o crescimento e multiplicação das leveduras. Além disso, as reservas de amido dos grãos são convertidas em açúcares, como glicose, maltose e dextrinas, assimiláveis pelas leveduras que realizarão a fermentação posteriormente. [9,33]. Após a resfriação e filtração, obtem-se o principal resíduo cervejeiro: o bagaço de malte.

O mosto segue para a etapa de fervura a $100{ }^{\circ} \mathrm{C}$ de 60 a 90 minutos, onde ocorrem as adições de lúpulo. A fervura promove a inativação de enzimas, esterelização do mosto, coagulação protéica, extração de compostos amargos e aromáticos do lúpulo, formação de substâncias constituintes do aroma e sabor, evaporação da água excedente e de componentes aromáticos indesejáveis ao produto final [34]. O líquido é então clarificado e resfriado, gerando resíduos de partículas de malte não filtradas e de lúpulo, denominados trub.

$\triangleright$ Fermentação

A fermentação do mosto é dividida em duas etapas. Numa primeira etapa, denominada aeróbia, as leveduras se reproduzem e multiplicam. Posteriormente inicia-se a fase anaeróbia, onde as leveduras realizam a fermentação propriamente dita, convertendo os açúcares presentes no mosto em $\mathrm{CO}_{2}$ e álcool [9].

Dois tipos de leveduras podem atuar na fermentação: Saccharomyces cerevisiea e a Saccharomyces uvarum, gerando dois tipos de fermentação: a alta fermentação para cervejas Ale, com temperatura entre 18 e $22{ }^{\circ} \mathrm{C}$ e duração de 3 a 5 dias; e a baixa fermentação para cervejas Lager, com temperatura entre 7 e $15{ }^{\circ} \mathrm{C}$ e duração de 7 a 10 dias [35].

O mosto fermentado é filtrado e mantido resfriado em torno de $0{ }^{\circ} \mathrm{C}$ nas dornas de maturação, onde ocorrem reações químicas que auxiliam 
no processo de estabilização do produto final, quanto à características relacionadas com o paladar e saturação com $\mathrm{CO}_{2}[9]$.

$\triangleright$ Envase

Uma vez concluída a produção da cerveja, esta deve ser devidamente envasada. Nesse processo deve-se ter cuidado com possíveis fontes de contaminação, perda de gás e contato da cerveja com oxigênio que podem comprometer a qualidade do produto. O envase pode ser feito em barris, gerando o chopp ou em garrafas seguidas de pasteurização, formando a cerveja [9].

\subsection{2}

\section{Bagaço de malte}

A maior parte do malte produzido é feito utilizando grãos de cevada como matéria prima. De acordo com a European Brewery Convention (EBC), existem mais de 500 tipos de cevada registrados com propriedades e características diferentes [36]. Além da cevada, outros grãos podem ser usados para a produção do malte, como o centeio e o trigo.

Cada receita de cerveja apresenta tipos e proporções de malte diferentes em sua composição, acarretando em diversos estilos da bebida. Pode-se dizer que nenhuma receita é igual a outra. Dessa forma, cada bagaço de malte terá uma composição única, apesar de características físico-químicas semelhantes entre si [36].

São gerados de 14 a $20 \mathrm{~kg}$ de bagaço de malte para cada $100 \mathrm{~L}$ de cerveja produzidos. Do ponto de vista ambiental, esse resíduo de biomassa é um problema, pois apresenta elevados teores de carboidratos, proteínas, gorduras e fibras, que lhe conferem uma demanda química de oxigênio cerca de cem vezes maior que a do esgoto doméstico para ser degradado [10].

Devido ao alto custo para a destinação correta do resíduo e gastos com distribuição e transporte, normalmente, as cervejarias possuem uma empresa terceirizada que é responsável pela comercialização do bagaço [37]. A cervejaria vende o bagaço de malte a baixo preço, em torno de $\mathrm{R} \$ 65,00$ a tonelada, sendo o principal destino a produção de ração animal. Entretanto, como o bagaço apresenta alta umidade, o consumo deve ser rápido, pois se torna um meio propício para crescimento de microrganismos indesejáveis, que diminuem a qualidade do produto, causam mal cheiro e podem levar os animais à morte caso haja produção de algum tipo de toxina por fungos e bactérias aeróbicas [38]. 
O bagaço de malte também pode ser utilizado na alimentação humana, com a fabricação de pães, produção de energia, incorporação em materiais de construção, produção de papel e pode seguir para outros empregos menos usuais, como a hidrólise para obtenção de xilo-oligossacarídeos, xilitol e meios de cultura ricos em pentoses ou emprego em processos biotecnológicos, sendo substrato para o crescimento de fungos e produção de enzimas [37].

\section{4}

\section{Processos de conversão da biomassa}

Devido ao grande volume de biomassa formado nos mais variados setores industriais e das dificuldades com transporte, manuseio e estocagem, surge uma motivação para sua conversão em produtos de maior valor agregado para serem usados como fontes de energia no próprio local de geração da biomassa. A conversão da biomassa segue principalmente duas rotas: bioquímica e termoquímica, como representadas na Figura 3.6.

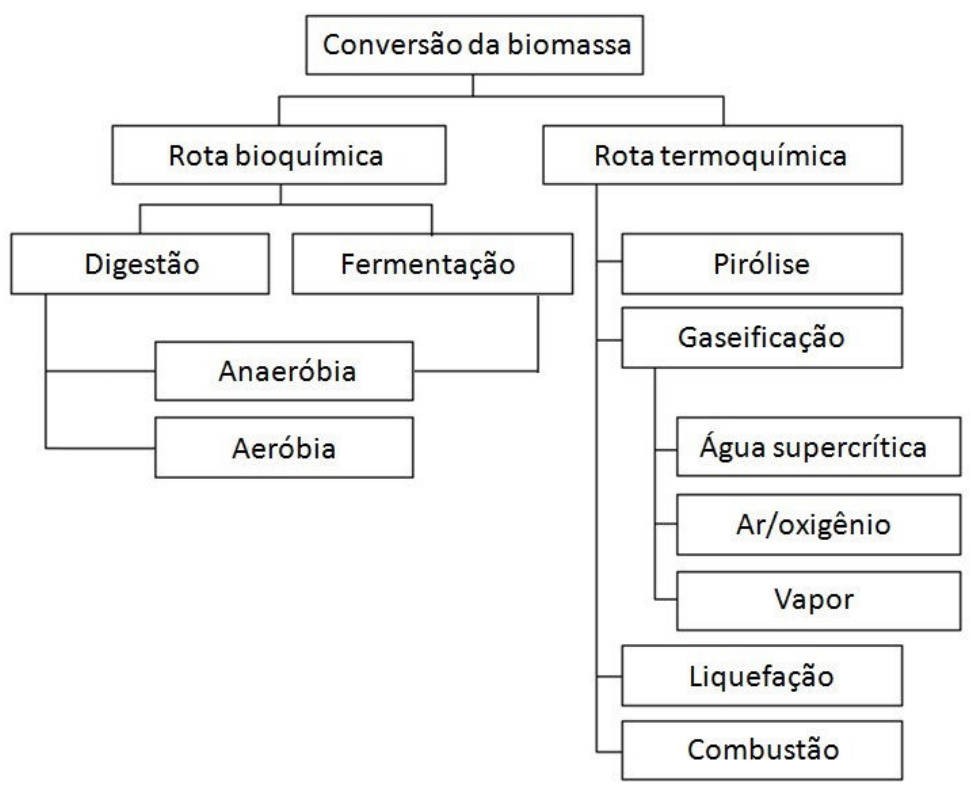

Figura 3.6: Principais processos de conversão da biomassa, adaptado de [19]

$\mathrm{Na}$ rota bioquímica, a biomassa é convertida em moléculas menores por ação de bactérias (digestão) ou enzimas (fermentação). Na digestão, os principais produtos formados são o metano e o dióxido de carbono, já na fermentação, o etanol é o produto de interesse. A rota bioquímica de conversão requer um alto tempo de processo no entanto tem como vantagem o fato de não necessitar de energia de fontes externas [19].

$\mathrm{Na}$ rota termoquímica, a biomassa é convertida, formando produtos sólidos, líquidos ou gasosos para a produção de energia, calor, produtos químicos ou combustíveis [39]. 
Cada processo apresenta características diferentes em seu modo de operação, conforme apresentado na Tabela 3.1

Tabela 3.1: Comparação dos principais processos de conversão termoquímica, adaptado de [19]

\begin{tabular}{ccccc}
\hline Processo & $\begin{array}{c}\text { Temperatura } \\
\left({ }^{\circ} \mathrm{C}\right)\end{array}$ & $\begin{array}{c}\text { Pressão } \\
(\mathrm{MPa})\end{array}$ & Catalisador & Secagem \\
\hline Liquefação & $250-380$ & $5-20$ & Essencial & Sem necessidade \\
Pirólise & $380-530$ & $0,1-0,5$ & Sem necessidade & Necessária \\
Combustão & $700-1400$ & $>0,1$ & Sem necessidade & Não essencial \\
Gaseificação & $500-1300$ & $>0,1$ & Não essencial & Necessária \\
\hline
\end{tabular}

A pirólise é conduzida em atmosfera com ausência de oxigênio e converte a biomassa em produtos sólidos (bio-carvão), líquidos (bio-óleo) ou gasosos dependendo das condições de operação, como faixa de temperatura e taxa de aquecimento do processo. Gaseificação converte a biomassa em gases e produtos químicos úteis, utilizando um meio reacional, que pode ser gás (ar, oxigênio, vapor subcrítico) ou água supercrítica. Combustão representa a reação exotérmica de queima da biomassa, convertendo os hidrocarbonetos presentes em $\mathrm{CO}_{2}$ e $\mathrm{H}_{2} \mathrm{O}$ e liberando calor para ser utilizado como energia. Liquefação tem como objetivo priorizar a formação de bio-óleo, através das condições de operação adotadas, no entanto, também há formação de subprodutos líquidos solúveis em água, biocarvão e produtos gasosos [19,39].

\subsection{1}

\section{Liquefação hidrotérmica}

A liquefação, também chamada de liquefação térmica, é o processo de conversão da biomassa, em elevada temperatura e pressão. Para isso, são utilizados solventes, que também atuam como catalisadores na reação, promovendo reações de hidrólise, fragmentação e repolimerização da biomassa, priorizando a formação de produtos liquefeitos [13]. Quando o solvente utilizado é a água, o processo denomina-se liquefação hidrotérmica (HTL). Na HTL diversas variáveis de processo influenciam nos produtos finais formados.

\section{Tipo de biomassa}

A composição da biomassa influencia diretamente nos produtos formados, em geral, biomassas com maior teor de hemicelulose e celulose produzem mais bio-óleo, já elevado teor de lignina, tende a dificultar a quebra e repolimerização das moléculas, diminuindo seu rendimento [12]. Isto ocorre devido a diferença na resistência térmica dos materias. 
Zhong e Wei (2004) estudaram o rendimento dos produtos após liquefação hidrotérmica de quatro diferentes biomassas, provenientes de resíduos de madeira, em temperaturas entre $280-360{ }^{\circ} \mathrm{C}$. O menor rendimento de bio-óleo obtido foi $17,24 \%$ a $280{ }^{\circ} \mathrm{C}$ e o maior foi $30,72 \%$ a $300{ }^{\circ} \mathrm{C}$ em diferentes biomassas. Já o resíduo sólido, biocarvão, apresentou maior rendimento, $30,29 \%$ a $280{ }^{\circ} \mathrm{C}$ e menor, $14,16 \%$ a $300{ }^{\circ} \mathrm{C}$, justamente na mesma biomassa que obteve maior rendimento de bio-óleo. Através de seus resultados, e da análise da composição das biomassas estudadas, os autores identificaram que a quantidade de bio-óleo gerada é inversamente proporcional ao teor de lignina presente na biomassa [40].

\section{Atmosfera da reação}

A função do gás presente na atmosfera reacional é estabilizar os produtos fragmentados na liquefação. Estudos indicam que espécies redutoras inibem a condensação, combinação ou repolimerização de radicais livres, diminuindo assim a quantidade de subprodutos indesejáveis. No entanto, espécies redutoras como o gás de síntese, composto de $\mathrm{CO}$ e $\mathrm{H}_{2}$, tem um alto custo de obtenção, dificultando a utilização para este propósito. Ar atmosférico pode ser usado na HTL, porém provoca a combustão da biomassa, gerando menor rendimento de produtos. Desta forma, atmosfera inerte, com gases como $\mathrm{N}_{2}$ e Ar, tende a apresentar uma melhor relação custo-benefício, sendo amplamente utilizada nesse processo [12].

Yin et al. (2010), estudaram essa variável e reportam rendimentos de bio-óleo de 48,76\% e 44,72\% em atmosfera redutora, 38,49\% em atmosfera inerte e apenas 27,97\% em ar atmosférico para o processo de HTL [41].

\section{Tamanho de partícula}

O objetivo da redução do tamanho das partículas é aumentar a área superficial de biomassa para a HTL, gerando maior grau de hidrólise e fragmentação. No entanto, a redução do tamanho da biomassa custa uma quantidade considerável de energia e tempo, portanto, um tamanho ideal de partícula deve aumentar o rendimento de produtos a baixo custo de moagem $[12]$.

Zhang et al. (2009) estudaram tamanhos de partícula entre 0,5 $\mathrm{mm}$ e 1 in $(25,4 \mathrm{~mm})$. Apesar do melhor rendimento ter sido obtido em $2 \mathrm{~mm}$, os pesquisadores decobriram que a variaçao do rendimento de produtos foi muito pequena, aproximadamente $6 \%$, constatando assim que o tamanho das partículas confere baixos efeitos na HTL, tornando-se um parâmetro secundário [42]. 


\section{Proporção de biomassa e água}

A razão de massa de biomassa para massa de água é considerada um parâmetro chave. Elevado volume de água aumenta a estabilidade e solubilidade de componentes craqueados durante o tratamento hidrotérmico, além disso, estudos também reportam que diminui o rendimento de biogás, aumentando rendimento dos demais produtos [12]. Dessa forma, a razão ideal depende do tipo de biomassa, assim, biomassas com alta umidade terão maior quantidade de água e consequentemente uma menor razão biomassa/massa total.

\section{Temperatura}

A temperatura é uma variável de grande importância pois influencia diretamente nos produtos formados. Temperaturas mais baixas, na faixa denominada carbonização hidrotérmica $\left(150-250{ }^{\circ} \mathrm{C}\right)$, tendem a formar mais bio-carvão devido a menor degradação das moléculas; temperaturas moderadas $\left(250-374{ }^{\circ} \mathrm{C}\right)$ priorizam a formação de bio-óleo no processo de HTL; já temperaturas mais elevadas (acima do ponto crítico da água, $374{ }^{\circ} \mathrm{C}$ ) geram maior rendimento de bio-gás no processo denominado gaseificação hidrotérmica, como representado na Figura 3.7. Vale ressaltar que independente da faixa de temperatura do processo, esses três produtos são formados além de um quarto produto, que consiste em uma fração de compostos solúveis em água $[43,44]$.

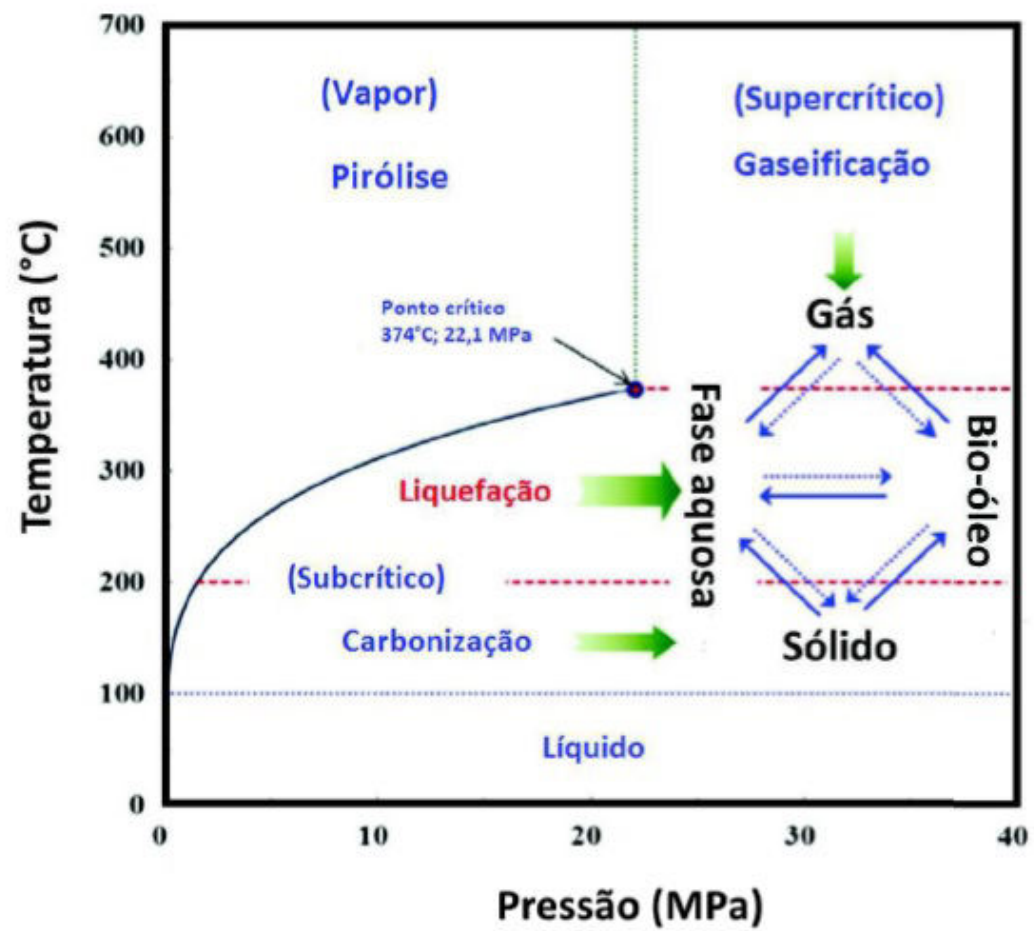

Figura 3.7: Influência da temperatura na formação de produtos [43] 
Estudos indicam que temperaturas inferiores a $280^{\circ} \mathrm{C}$ levam à degradação incompleta de biopolímeros e baixos rendimentos de bio-óleo [12]. Karagöz et al. (2006) obtiveram rendimentos de bio-óleo entre 6,4 - 8,6\% para um processo de HTL a $280{ }^{\circ} \mathrm{C}$ [45]. Já Singh et al. (2015), obtiveram rendimentos de bio-óleo entre $7-12 \%$ para a mesma temperatura [46].

Um grande número de artigos relatam a existência de uma temperatura ótima de HTL, para a formação de bio-óleo, próxima a $300{ }^{\circ} \mathrm{C}$ para a maioria dos substratos [44]. Zhou et al. (2010) estudaram a formação de bio-óleo em diferentes faixas de temperaturas e concluíram que seu rendimento cresce até $300{ }^{\circ} \mathrm{C}$, atingindo o valor máximo, 20,4\%, nessa temperatura, e decresce após $320{ }^{\circ} \mathrm{C}$ [47]. Para Sugano et al. (2008) o melhor rendimento de bio-óleo também ocorreu a $300{ }^{\circ} \mathrm{C}$ com rendimento de $11,0 \%$ [48].

\section{Pressão}

Alta pressão do sistema é outro fator importante, responsável por manter a água em um único estado físico (líquido) ao longo de toda a reação, evitando assim uma grande variação de entalpia relacionada ao calor latente de vaporização do solvente. Mantendo o sistema fechado e a pressão ligeiramente acima da pressão de vapor da água em determinada temperatura, evita-se a mudança de estado físico e faz com que a taxa de hidrólise e decomposição da biomassa seja aumentada, favorecendo termodinamicamente a formação de produtos liquefeitos [12].

\section{Taxa de aquecimento}

De maneira geral, em processos de conversão térmica, elevadas taxas de aquecimento tendem a favorecer a fragmentação da biomassa, aumentando o rendimento de produtos. No caso da HTL, maior quantidade de bio-óleo e menor quantidade de biocarvão são formadas. No entanto, há indicativos de que rápido aquecimento no processo hidrotérmico gera poucos efeitos na formação do produto final [12].

Zhang et al. (2009) estudaram esse efeito e reportaram que taxas de aquecimento de 5 e $14{ }^{\circ} \mathrm{C} \cdot \mathrm{min}^{-1}$ não apresentaram diferenças significativas no produto final, gerando rendimentos médios de $61,1 \%$ a $65,2 \%$ de produtos líquidos e 19,2\% a 22,9\% de biocarvão, porém, quando o desvio padrão desses resultados é levado em conta, nota-se que os valores podem ser considerados os mesmos para ambas as taxas de aquecimento. Apenas quando elevaram a taxa de aquecimento para $140{ }^{\circ} \mathrm{C} \cdot \mathrm{min}^{-1}$, perceberam aumento significativo de produtos líquidos, atingindo valores de até $76 \%$ e queda no produto sólido, gerando rendimento de apenas 8,6\% [42]. 


\section{Tempo de residência}

Na HTL ocorrem sucessivas reações de hidrólise, fragmentação e repolimerização das moléculas. As reações de quebra são dominantes durante os estágios iniciais, já a repolimerização torna-se mais presente em fases posteriores, assim, o tempo de residência do processo é outro fator importante [12]. Estudos reportam que estas reações ocorrem durante a fase de aquecimento quando utilizadas baixas taxas de aquecimento, assim, não seriam necessários altos tempos de residência.

Zhou et al. (2010) reportaram o tempo de 30 minutos como o melhor do processo, obtendo rendimento de 20,4\% de bio-óleo, no entanto, levemente acima do tempo de 5 minutos, onde obteve-se 15,2\% de bio-óleo. Identificaram também, que após 30 minutos o rendimento decai [47].

Fato semelhante foi observado por Yin et al. (2010). O rendimento de bio-óleo foi maior utilizando tempo de residência de 0 minutos, isto é, iniciou-se o resfriamento do reator imediatamente após a temperatura final ser alcançada. Em 0 minutos obteve-se 39,57\% de bio-óleo, valor que se manteve sem significativa alteração até 15 minutos de tempo de residência. Em tempos superiores, observou-se rápido decréscimo na geração de bio-óleo, chegando a $12,95 \%$ em 40 minutos [41].

A Tabela 3.2 representa a influência de algumas das variáveis mais importantes no processo de HTL, exemplificadas anteriormente.

Tabela 3.2: Influência das variáveis no processo de HTL

\begin{tabular}{ccccccc}
\hline $\begin{array}{c}\text { Tipo de } \\
\text { biomassa }\end{array}$ & $\begin{array}{c}\text { Razão m/m } \\
\text { biomassa/ } \\
\text { solvente }\end{array}$ & $\begin{array}{c}\text { T final } \\
\left({ }^{\circ} \mathrm{C}\right)\end{array}$ & $\begin{array}{c}\text { Tempo } \\
(\mathrm{min})\end{array}$ & $\begin{array}{c}\text { Bio-óleo } \\
(\%)\end{array}$ & $\begin{array}{c}\text { Biocarvão } \\
(\%)\end{array}$ & Referência \\
\hline Pinheiro & $1 / 12,5$ & 280 & 10 & 17,34 & 27,83 & {$[40]$} \\
Pinheiro & $1 / 12,5$ & 300 & 10 & 30,72 & 14,16 & {$[40]$} \\
Esterco & $1 / 4$ & 310 & 0 & 39,57 & 9,00 & {$[41]$} \\
Esterco & $1 / 4$ & 310 & 15 & 38,49 & 10,50 & {$[41]$} \\
Esterco & $1 / 4$ & 310 & 40 & 12,95 & 24,20 & {$[41]$} \\
Madeira & $1 / 6$ & 280 & 15 & 8,60 & 42,00 & {$[45]$} \\
Madeira & $1 / 3$ & 280 & 15 & 6,40 & 45,00 & {$[45]$} \\
Alga & $1 / 6$ & 280 & 15 & 12,00 & 19,00 & {$[46]$} \\
Alga & $1 / 7,5$ & 300 & 5 & 15,20 & 17,10 & {$[47]$} \\
Alga & $1 / 7,5$ & 300 & 30 & 20,40 & 16,90 & {$[47]$} \\
Eucalipto & $1 / 6$ & 300 & 0 & 11,00 & 41,00 & {$[48]$} \\
\hline
\end{tabular}




\section{4 .2}

\section{Produtos gerados}

\section{Bio-óleo}

O bio-óleo é um combustível renovável formado pela liquefação da biomassa, sendo principal produto produzido durante o processo de HTL. Apresenta coloração marrom escura, quase negra, possui forte odor e composição elementar próxima a da biomassa. Seu conteúdo energético e suas propriedades físicas e químicas são altamente dependentes da composição da biomassa empregada e das condições experimentais utilizadas [49].

O grande interesse nesse tipo de combustível ocorre devido ao seu alto potencial energético, alcançando valores de poder calorífico superior (PCS)

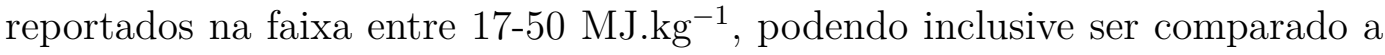
combustíveis tradicionais como o petróleo, diesel e gasolina que possuem PCS de 45,54, 45,77 e 46,54 MJ. $\mathrm{kg}^{-1}$ respectivamente [50, 51].

Após o processo de HTL, a fase líquida é filtrada, no entanto, o bio-óleo, que não é solúvel em água, permanece impregnado a fase sólida, necessitando de um solvente orgânico de extração, geralmente diclorometano ou acetona, para ser obtido de forma pura [43]. Uma caracterização parcial dos compostos existentes no bio-óleo pode ser realizada por meio de cromatografia gasosa, mas muitos compostos pesados podem permanecer não identificados em diferentes tipos de coluna. De maneira geral, são identificados diversos compostos como hidrocarbonetos alifáticos, hidrocarbonetos cíclicos, compostos oxigenados cíclicos, compostos nitrogenados, ácidos carboxílicos, aldeídos, cetonas, álcoois e ésteres [43, 49].

\section{Biocarvão}

O biocarvão é um dos produtos secundários formando na HTL, por esse motivo, muitas vezes é visto como um resíduo sólido de baixo potencial de reaproveitamento uma vez que existem outros processos de conversão térmica para melhorar seu rendimento e propriedades. Esse subproduto consiste em compostos inorgânicos e compostos orgânicos não degradados e reestruturados, possui elevado conteúdo de cinzas e pouco hidrogênio, enxofre e nitrogênio [43].

Poucos estudos sobre o biocarvão produzido na HTL são reportados na literatura. Chen et al. (2014) reportaram que não existe uma correlação exata entre o tempo de residência e o rendimento de resíduo sólido, identificando assim que a decomposição e repolimerização da biomassa ocorrem simultaneamente. Além disso, através de análises termogravimétricas reportaram que o bio-carvão pode ser usado como combustível para gerar energia ou como asfalto após processos de craqueamento e beneficiamento [52]. 


\section{Produtos gasosos}

Os produtos gasosos formados durante a HTL são de baixo interesse. Normalmente, não possuem rendimento superior a $20 \%$ em condições típicas de operação.

Zhang et al. (2009) identificaram que o rendimento de gás é maior com o aumento da temperatura de processo, alcançando $27 \%$. No entanto, isso faz com que o rendimento de bio-óleo diminua. Na temperatura de maior rendimento de bio-óleo $\left(300{ }^{\circ} \mathrm{C}\right)$, obtiveram apenas $8 \%$ de produto gasoso. Através da sua caracterização por cromatografia gasosa identificou-se a presença de hidrogênio, monóxido de carbono, metano e dióxido de carbono em proporções de 1-5\%, 12-24\%, 0-5\% e 67-87\% respectivamente [42].

Como o rendimento de produtos gasosos é inversamente proporcional a produção de bio-óleo, este produto acaba tendo pouco interesse de produção no processo de HTL.

\section{Produtos solúveis em água}

Os produtos solúveis em água (psa) são gerados em todos os processos termoquímicos hidrotérmicos, apresentando o maior rendimento se comparado aos sólidos e gases. Como o bio-óleo é insolúvel na fase aquosa, este pode ser facilmente separado [43].

Através da caracterização dos psa, é possível identificar concentrações elevadas de $\mathrm{NH}^{+4}, \mathrm{PO}_{4}^{-3}$, ácidos orgânicos voláteis e outros cátions metálicos como $\mathrm{K}^{+}, \mathrm{Na}^{+}$e $\mathrm{Mg}^{+2}$. Alguns estudos relacionam os psa como importante fonte de nutrientes que podem ser usado para o cultivo e crescimento de algas [43]. 
4

\section{Materiais e Métodos}

\section{1}

\section{Biomassa de bagaço de malte}

O resíduo de bagaço de malte foi obtido de uma cervejaria artesanal da região. Como o conteúdo de bagaço de malte depende de cada receita, o presente trabalho utilizou sempre a mesma matéria-prima para os experimentos. O conteúdo consistia nos maltes comerciais na proporção em massa: 81\% Maris Otter - Thomas Fawcett; 7,3\% Pale Crystal - Thomas Fawcett; 4,1\% Munich Light - Viking; 2,8\% Black Malt - Viking; 2,6\% Carafa III - Weyermann e 2,3\% Rye Malt - BestMalz.

Uma pequena amostra da biomassa foi retirada para identificação do teor de umidade presente logo após o processo cervejeiro. Apesar da HTL operar com altas concentrações de água, o bagaço de malte utilizado foi seco em estufa a $70^{\circ} \mathrm{C}$ até a massa permanecer constante, para reduzir a umidade do material, evitando assim a proliferação de microrganismos, fungos e formação de maus odores que, a longo prazo, poderiam comprometer o resultado deste trabalho. O material seco foi homogeneizado e armazenado. A Figura 4.1 representa o bagaço de malte seco utilizando nos experimentos.

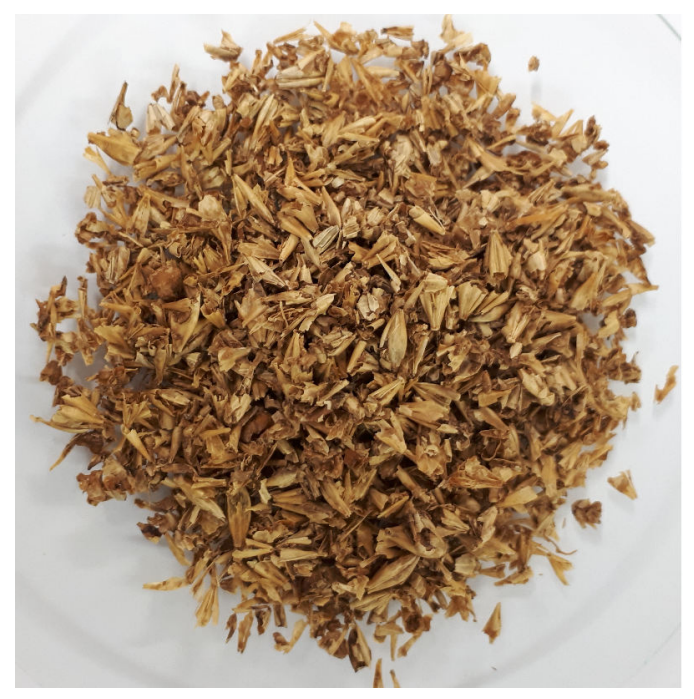

Figura 4.1: Bagaço de malte 


\section{2}

\section{Caracterização do bagaço de malte}

\subsection{1}

\section{Teor de umidade}

Identificar o teor de umidade da amostra como recebida é de extrema importância na HTL, com a finalidade de utilizar uma proporção de biomassa e água próxima ao valor obtido. Desta forma, apesar do bagaço de malte ter sido seco anteriormente, é possível retornar este valor de umidade original para ser feita a HTL.

A umidade foi realizada colocando amostras de 10,0 g de bagaço de malte em estufa a $70{ }^{\circ} \mathrm{C}$, até que massa permanecesse constante. A diferença entre a massa inicial e final é a quantidade de água evaporada. Dessa forma, a umidade inicial do material foi definida como:

$$
\operatorname{Umidade}(\%)=\frac{W_{0}-W}{W_{0}} .100
$$

Onde $W_{0}$ é a massa inicial e $W$ é a massa final de biomassa.

\subsection{2}

\section{Análise granulométrica}

A análise granulométrica foi realizada utilizando $60,0 \mathrm{~g}$ do bagaço de malte seco. A abertura das peneiras foi de $3,36 \mathrm{~mm}, 2,38 \mathrm{~mm}, 1,40 \mathrm{~mm}$, 0,71 mm, 0,35 mm e o fundo sem abertura. O material ficou sob agitação mecânica durante 20 min para separar cada porção de acordo com o tamanho de partícula.

A proporção de partículas retida em cada peneira é definida como:

$$
\text { Proporção }(\%)=\frac{W}{W_{0}} \cdot 100
$$

Onde $W_{0}$ é a massa inicial da amostragem e $W$ é a massa que ficou retida em cada peneira.

\subsection{3}

\section{Densidade e porosidade}

A densidade aparente é a razão da massa do material pelo volume ocupado por este adicionado ao volume dos poros. Já no cálculo da densidade relativa, os poros devem estar totalmente preenchidos com o solvente (em geral, água). A porosidade é definida como: 


$$
\epsilon(\%)=\frac{\rho_{\text {relativa }}-\rho_{\text {aparente }}}{\rho_{\text {relativa }}} .100
$$

Onde $\epsilon$ é a porosidade e $\rho$ representa cada densidade.

Para o cálculo de ambas as densidades e da quantidade de poros presentes, foi utilizado o procedimento e os cálculos presentes na norma ABNT NBR 6458:2016 Errata 2:2017 que leva em conta a densidade de particulados sólidos.

\subsection{4}

\section{Composição da biomassa}

Apesar de diversos artigos apresentarem faixas de composição de cada biomassa, essa é uma característica única do material, desta forma é de grande importância descobrir os teores de extrativos, umidade, celulose, hemicelulose, lignina e cinzas. Assim, é possível identificar quais materiais são passíveis de serem degradados e quais os possíveis rendimentos dos produtos da HTL.

O teor de cinzas e umidade foi realizado utilizando a Norma ASTM D1762-84 (2013) que diz respeito a análise imediata de biomassas.

O teor de extrativos foi feito utilizando base seca, através da Norma TAPPI T204 cm-97, celulose e hemicelulose através da TAPPI T249 cm-85 e lignina pela TAPPI T222 om-98, seguindo a mesma metodologia utilizada por Pasquini et al. (2005), onde realizaram os mesmos testes para o bagaço de cana-de-açúcar [53].

Como as metodologias adotadas foram realizadas com base seca, logo após retirada da estufa, deve-se acrescentar o teor de umidade presente no material, identificado na biomassa de estudo. Por fim, deve-se descontar o valor das cinzas do valor da lignina encontrado.

\section{3}

\section{Processo de liquefação hidrotérmica}

Os experimentos foram realizados nas dependências do Laboratório de Engenharia Química e de Materiais da Casa XXI na PUC-Rio. O processo HTL foi conduzido em reator tipo autoclave Parr modelo $452 \mathrm{HC} 2$ de $0,5 \mathrm{~L}$ de capacidade máxima. Bagaço de malte e água destilada na temperatura ambiente foram adicionados na proporção de 10,0 g de biomassa e 190,0 g de água, formando uma proporção $1 / 20$ de biomassa/massa total, o que representa uma amostra com $95 \%$ de umidade. Nessa proporção, todo o material encontrou-se imerso na água. 
O tempo de processo foi considerado a partir do momento em que iniciouse o aquecimento da autoclave, já o tempo de residência foi considerado apenas quando o processo atingiu a temperatura final.

Para os experimentos foram adotados os tempos de residência de 5, 30 e 60 minutos e as temperaturas de 250,275 e $300{ }^{\circ} \mathrm{C}$, garantindo variação significativas e dentro da faixa estudada por demais pesquisadores discutidos anteriormente.

Um purga foi realizada com gás inerte, argônio, por 7 min a uma pressão de 17 psi para a retirada do oxigênio, garantindo maior rendimento dos produtos. Em seguida, o sistema foi fechado e aquecido a uma taxa de 10 ${ }^{\circ}$ C.min ${ }^{-1}$ por uma manta térmica até alcançar as temperaturas estipuladas. Após a reação nas faixas de tempo determinadas, a autoclave foi resfriada em refrigeração forçada com água e aberta após a liberação da pressão ao chegar a $50{ }^{\circ} \mathrm{C}$. Encerrando-se a marcação do tempo total de processo. Os equipamentos utilizados podem ser observados na Figura 4.2.

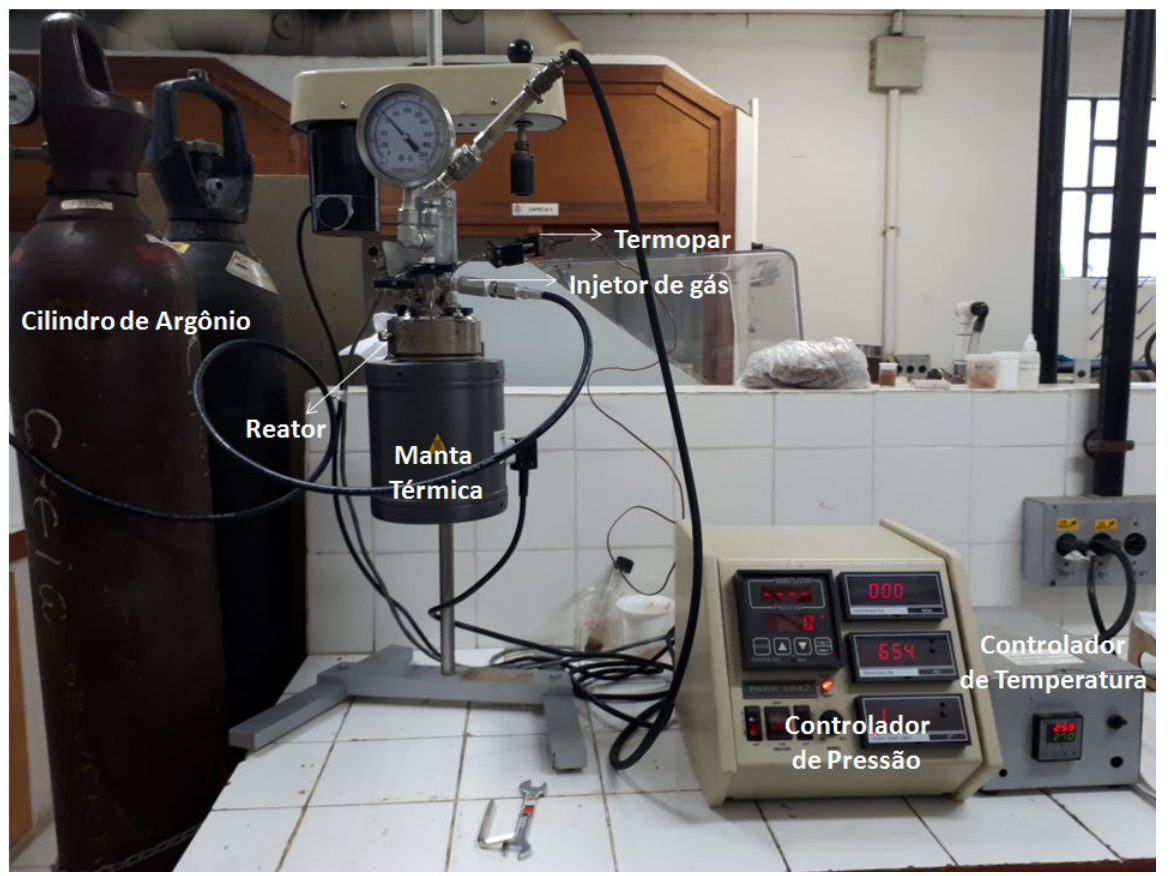

Figura 4.2: Processo HTL em operação

Os produtos gasosos saíram do processo no momento em que a válvula foi aberta para liberar a pressão do reator, possibilitando sua abertura. A fração sólida e líquida foi levada para a filtração a vácuo onde retiraram-se os produtos solúveis em água. A parte sólida foi colocada em estufa a $70{ }^{\circ} \mathrm{C}$ até peso constante para a retirada da umidade presente. O material foi levado para a extração Soxhlet utilizando $200 \mathrm{~mL}$ de acetona, uma vez que o bioóleo, impregnado no sólido, possui alta solubilidade nesse solvente. A extração ocorreu por 5 horas com 3-5 refluxos por hora. A parte sólida restante foi seca 
em estufa a $70{ }^{\circ} \mathrm{C}$ até peso constante, obtendo o biocarvão. A fração líquida foi levada para a destilação possibilitando a recuperação da acetona. O bioóleo, com resquícios de solvente foi deixado em temperatura ambiente para a evaporação da acetona final, obtendo assim, o bio-óleo purificado.

A Figura 4.3 representa o diagrama de blocos do processo de HTL para a obtenção dos quatro produtos gerados.

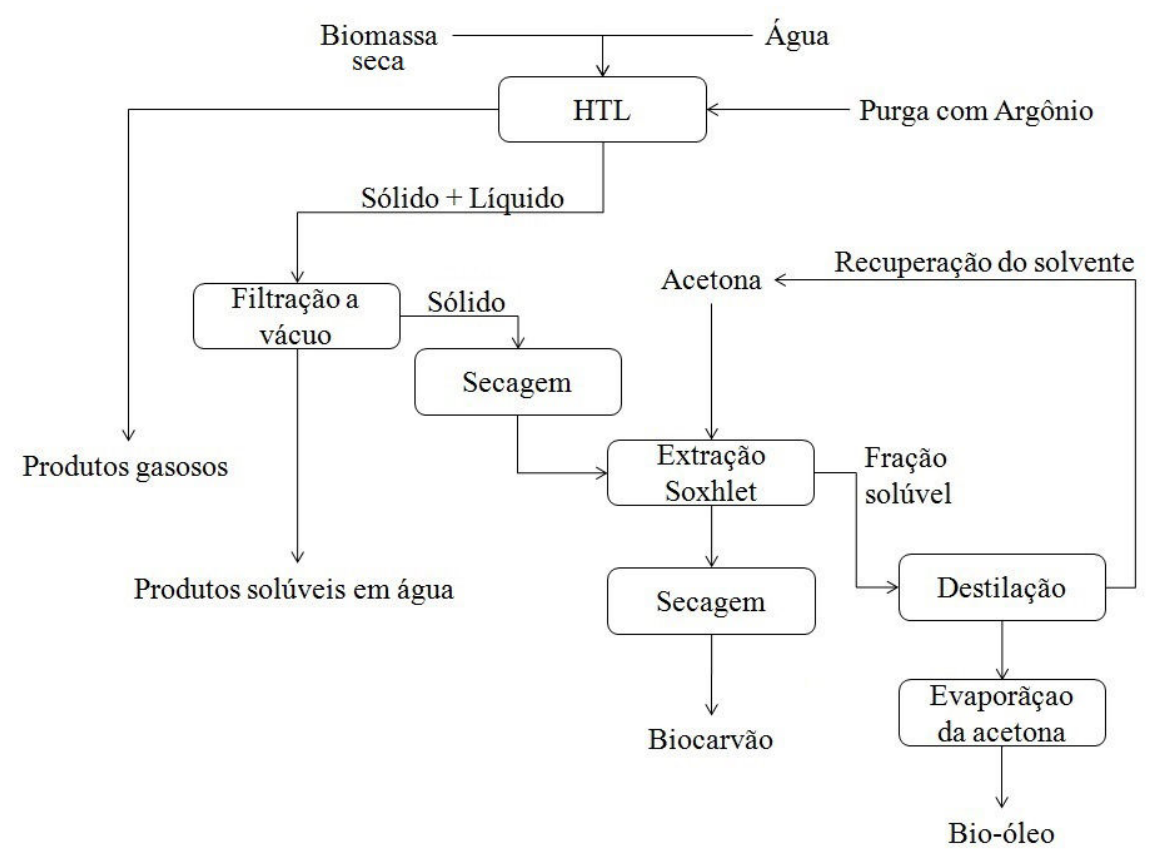

Figura 4.3: Diagrama de blocos do processo de HTL

\subsection{1}

\section{Modelagem cinética de liquefação}

Durante o processo de liquefação ocorrem diversas reações complexas como a solvolise da biomassa, despolimerização da celulose, hemicelulose e lignina e decomposição termoquímica dos monômeros, simultaneamente. Dessa forma, torna-se impossível medir cada uma de forma individual, assim como produtos formados. No entanto, é possível medir o rendimento dos produtos liquefeitos assim como o conteúdo de biomassa residual ao longo do tempo de reação em diferentes temperaturas, tornando possível uma modelagem e obtenção das constantes cinéticas do processo [54].

Nesse caso, a temperatura final deve ser baixa e o tempo de residência alto, fazendo com que toda a biomassa capaz de se liquefazer na temperatura determinada passe para a fase líquida, porém sem haver formação dos produtos da HTL. Nesta modelagem, foram usadas as temperaturas de 120, 140, 160 e $180{ }^{\circ} \mathrm{C}$ com tempos de residência variando entre 10 e 210 minutos. 
A razão de liquefação, equivalente a quantidade de biomassa capaz de se degradar e passar para o estado líquido, foi definida como a razão da biomassa que foi liquefeita em água em relação ao conteúdo total de biomassa na alimentação, calculada como:

Razão de liquefação:

$$
\alpha=\frac{W_{0}-W}{W_{0}}
$$

Conteúdo residual:

$$
1-\alpha=\frac{W}{W_{0}}
$$

Onde $\alpha$ é a razão de liquefação, $W_{0}$ é a massa inicial de alimentação da biomassa e $W$ é a massa final do conteúdo que não foi liquefeito no processo.

Na liquefação o conteúdo de solvente no interior da autoclave permanece constante, não sendo levado em conta na cinética da reação. Assume-se que a taxa da reação estará relacionada somente com a biomassa residual em qualquer instante de tempo, sem existir relação com outras condições do processo [55].

A constante de velocidade da reação pode ser medida pela equação de Arrhenius:

$$
k=A \cdot e^{-\frac{E a}{R T}}
$$

Onde $k$ é a constante de velocidade, $A$ é o fator de frequência, $E a$ é a energia de ativação, $R$ é a constante dos gases e $T$ é a temperatura de processo.

Na cinética de liquefação, a constante $n$ é definida como a ordem aparente da reação [55]. Desta forma, o modelo cinético para a liquefação da biomassa usando água como solvente pode ser expresso como:

$$
\frac{d \alpha}{d t}=k(1-\alpha)^{n}
$$

A linearização da equação cinética utilizando o logarítimo será:

$$
\ln \left(\frac{d \alpha}{d t}\right)=\ln (k)+n \cdot \ln (1-\alpha)
$$

A equação anterior é análoga a uma equação de reta do tipo $y=a . x+b$, dessa forma, traçando o gráfico da reta acima com os valores de $\alpha$ em cada instante de tempo $t$, é possível descobrir a ordem aparente da reação $(n)$, e a constante de velocidade $k$.

Linearizando a Equação (4-6) obtem-se:

$$
\ln (k)=\ln (A)-\frac{E a}{R} \cdot \frac{1}{T}
$$

Por fim, traçando o gráfico da equação anterior, com os valores de $k$ em cada temperatura $T$, é possível determinar os valores experimentais do fator de 
frequência $(A)$ e da energia de ativação $(E a)$, completando assim os principais parâmetros cinéticos.

\subsection{2}

\section{Termodinâmica via Teoria do Estado de Transição}

A termodinâmica é parte fundamental de todas as reações químicas que busca compreender as relações entre calor, trabalho e energia. A relação entre os parâmetros cinéticos e a termodinâmica da HTL pode ser baseada na Teoria do Estado de Transição.

De maneira geral, nesta teoria, define-se um estágio intermediário de transição de uma reação, denominado complexo ativado, em que não há reagentes, porém, os produtos ainda não se formaram. Apesar de algumas moléculas no estado de transição retornarem a condições iniciais dos reagentes, muitas superam a configuração desse estado, formando os produtos [56, 57].

Para esta teoria ser utilizada, numa primeira etapa os reagentes entram em equilíbrio com o estado intermediário e este então dará origem aos produtos da reação, segundo a expressão:

$$
A+B \leftrightarrows A B^{*} \rightarrow \text { produtos }
$$

Dessa forma, a Teoria do Estado de Transição pode ser utilizada na primeira etapa da HTL, onde só ocorreu a degradação da biomassa em produtos liquefeitos, sem haver formação de bio-óleo, biocarvão e demais produtos. Neste caso, $A$ seria água, $B$ seria a biomassa de bagaço de malte e $A B^{*}$ o estado intermediário de produtos liquefeitos.

Nesta teoria é utilizada a equação de Eyring, Equação (4-10), para relacionar a constante de velocidade da reação, $k$, obtida na modelagem cinética, com a temperatura de processo:

$$
k=\frac{k_{b} \cdot T}{h} \cdot k_{e q}
$$

Onde $k$ é a constante de velocidade, $k_{b}$ é a constante de Boltzmann, $T$ é a temperatura de processo, $h$ é a constante de Planck e $k_{e q}$ é a constante de equilíbrio.

Para o estado de transição:

$$
k_{e q}=e^{-\frac{\Delta G^{*}}{R \cdot T}}
$$

Onde $\Delta G^{*}$ é a variação da energia livre de Gibbs do produto intermediário liquefeito. 
Substituindo a Equação (4-11) na Equação (4-10) é possível encontrar a relação entre a energia livre de Gibbs do estado de transição, a temperatura e a constante de velocidade determinada pela modelagem cinética:

$$
k=\frac{k_{b} \cdot T}{h} \cdot e^{-\frac{\Delta G^{*}}{R \cdot T}}
$$

Escrevendo o $\Delta G^{*}$ do estado de transição em função de entropia e entalpia:

$$
k=\frac{k_{b} \cdot T}{h} \cdot e^{-\frac{\Delta H^{*}}{R \cdot T}} \cdot e^{\frac{\Delta S^{*}}{R}}
$$

A Equação (4-13) refere-se à mudança de entalpia para a formação do estado de transição, $\Delta H^{*}$, e à mudança de entropia para a formação da transição estado, $\Delta S^{*}$.

Utilizando a equação de Arrhenius linearizada, Equação (4-9), adotada na modelagem cinética:

$$
\ln (k)=\ln (A)-\frac{E a}{R} \cdot \frac{1}{T}
$$

Derivando em função da temperatura:

$$
\frac{\delta \ln (k)}{\delta T}=\frac{E a}{R \cdot T^{2}}
$$

Rearranjando:

$$
E a=R T^{2} \cdot \frac{\delta \ln (k)}{\delta T}
$$

Substituindo a Equação (4-13) na Equação (4-15):

$$
E a=R T^{2} \cdot \frac{\delta \ln \left(\frac{k_{b} \cdot T}{h} \cdot e^{-\frac{\Delta H^{*}}{R \cdot T}} \cdot e^{\frac{\Delta S^{*}}{R}}\right)}{\delta T}
$$

Através da Equação (4-16) é possível obter uma relação entre a energia de ativação e os parâmetros termodinâmicos. No entanto, essa relação depende de como a reação é conduzida no interior do reator, sendo afetada pela pressão interna do sistema, podendo seguir por duas diferentes rotas $[57,58]$.

No primeiro caso, a reação ocorre em solução com a água em estado líquido, já no segundo caso, a água encontra-se em fase gasosa.

A variação de entalpia dentro do sistema pode ser expressa como:

$$
\Delta H^{*}=\Delta U^{*}+P . \Delta V
$$


1. Reação em solução

Para a reação em solução, não há variação de volume, logo a variação de entalpia é igual a variação da energia interna:

$$
\Delta H^{*}=\Delta U^{*}
$$

Substituindo a Equação (4-18) na Equação (4-16) e resolvendo a derivada em função da temperatura:

$$
E a=R T^{2} \cdot \frac{R \cdot T+\Delta U^{*}}{R \cdot T^{2}}
$$

Reorganizando a Equação (4-19) e substituindo energia interna por entalpia, finalmente é possível identificar a relação entre a entalpia do estado de transição e a energia de ativação obtida pelo modelo cinético para o caso em que a reação de liquefação ocorre em solução:

$$
\Delta H^{*}=E a-R \cdot T
$$

2. Reação em fase gasosa

Neste caso, ocorre variação no volume da Equação (4-17) na qual, para gases ideais, é expressa como:

$$
\Delta H^{*}=\Delta U^{*}+\Delta n \cdot R \cdot T
$$

Onde $\Delta n$ é a diferença entre a molecularidade dos produtos do estado de transição e dos reagentes.

Substituindo a Equação (4-21) na Equação (4-16) e resolvendo a derivada em função da temperatura, obtem-se a mesma expressão da Equação (4-19). No entanto, neste caso, a relação entre $\Delta U^{*}$ e $\Delta H^{*}$ é diferente, gerando a expressão para a reação em fase gasosa:

$$
\Delta H^{*}=E a-R \cdot T+\Delta n \cdot R \cdot T
$$

Como há a formação de um produto no estado de transição (produto liquefeito) e dois reagentes iniciais (água e biomassa), sendo uma reação bimolecular, o valor de $\Delta n$ é igual a -1, finalmente chegando a relação:

$$
\Delta H^{*}=E a-2 R \cdot T
$$


Utilizando a equação termodinâmica da energia livre de Gibbs para relacionar $\Delta G^{*}$ e $\Delta H^{*}$ do estado de transição:

$$
\Delta G^{*}=\Delta H^{*}-T \cdot \Delta S^{*}
$$

Finalmente obtem-se que:

$$
\Delta S^{*}=\frac{\Delta H^{*}-\Delta G^{*}}{T}
$$

Dessa forma, através da Teoria do Estado de Transição é possível identificar os valores de energia livre de Gibbs, entalpia e entropia da primeira etapa do processo HTL, correspondente a degradação da biomassa para formar produtos liquefeitos.

\subsection{3}

\section{Rendimento e produtividade}

A diferença entre rendimento e produtividade é de grande importância na hora de definir os resultados finais de um processo. Rendimento equivale a quantidade de produtos que se obtêm ao final do processo. Na HTL, os rendimentos dos quatro produtos formados variam principalmente com a temperatura e tempo de residência. Já a produtividade equivale ao rendimento produzido de cada material ao longo de todo período de processo.

Esses dois conceitos são aplamente utilizados no momento de definir um ponto ótimo de condições de operação. Isso ocorre pois apesar de haver um ponto com maior rendimento, o tempo para se chegar a essa produção é tão alto que o torna inferior a pontos com menores tempos de processo. Assim, o ponto ótimo de operação será aquele com maior produtividade dos produtos desejados.

O rendimento dos produtos da HTL foram definidos como:

$\triangleright$ Produtos gasosos e produtos solúveis em água:

$$
R_{g p s a}(\%)=\frac{W_{0}-S_{0}}{W_{0}} .100
$$

Onde $R_{\text {gpsa }}$ é o rendimento de produtos gasosos somados aos produtos solúveis em água, $W_{0}$ é a massa inicial de biomassa e $S_{0}$ é a massa da fração sólida após filtragem e secagem, constituída por bio-óleo e biocarvão. 
$\triangleright$ Biocarvão:

$$
R_{b c}(\%)=\frac{S}{W_{0}} \cdot 100
$$

Onde $R_{b c}$ é o rendimento de biocarvão, $S$ é a massa da fração sólida após a extração soxhlet e secagem em estufa e $W_{0}$ é a massa inicial de biomassa.

$\triangleright$ Bio-óleo:

$$
R_{b o}(\%)=\frac{S_{0}-S}{W_{0}} .100
$$

Onde $R_{b o}$ é o rendimento de bio-óleo, $S_{0}$ é a massa de sólidos com bioóleo, $S$ é a massa da fração sólida após a extração soxhlet e secagem em estufa e $W_{0}$ é a massa inicial de biomassa.

A produtividade foi definida como a relação entre o rendimento de cada produto e o tempo total do processo HTL.

$$
\text { Produtividade }\left(\% \cdot \text { min }^{-1}\right)=\frac{R_{\text {produto }}}{t}
$$

\section{4 \\ Caracterização da biomassa e dos produtos gerados}

\subsection{1}

\section{Poder calorífico superior}

O poder calorífico superior (PCS) é a quantidade de energia, por unidade de massa, liberada por um material, quando este entra em combustão, com excesso de ar, e os gases da descarga são resfriados de modo que o vapor de água neles seja condensado. Logo, quanto mais alto for o valor do PCS, maior será a energia contida no material e maior será o seu potencial de uso como biocombustível.

O PCS do bagaço de malte, do biocarvão e do bio-óleo foram realizados no Laboratório de Físico-Química da PUC-Rio, utilizando uma bomba calorimétrica adiabática, seguindo os procedimentos da Norma ABNT NBR 11956:1990.

No procedimento, uma pastilha do material foi presa com um fio de cobre ligado a um eletrodo. Os componentes foram colocados em um compartimento, sob atmosfera saturada de $\mathrm{O}_{2}$ e alta pressão, e este permaneceu imerso em 
água. A descarga elétrica gerou a combustão do material e todo calor liberado foi usado para aquecer a água ao redor. Dessa forma, através da diferença de temperatura da água e da capacidade calorífica da bomba, foi possível determinar o PCS do material.

A capacidade calorífica da bomba foi determinada usando ácido benzóico como padrão. O PCS da biomassa e do biocarvão foram determinados diretamente através da diferença de temperatura da água ao ser aquecida na combustão do material. O PCS do bio-óleo foi determinado relacionando a fração sólida com esse componente impregnado, com o biocarvão após a extração total do bio-óleo.

\subsection{2}

\section{Análise imediata}

Com este método foi possível determinar a porcentagem de umidade, material volátil, cinzas e carbono fixo nas amostras de biomassa antes, e no biocarvão, após o processo de HTL, identificando assim as principais diferenças na composição. O ensaio foi realizado utilizando a Norma ASTM D1762-84 (2013).

\subsection{3}

\section{Análise elementar}

A Análise elementar - CHNS é uma técnica para determinação das porcentagens de carbono, hidrogênio, nitrogênio e enxofre em uma amostra. O ensaio foi conduzido no Departamento de Química da PUC-Rio, utilizado um analisador PerkinElmer PE-2400 - CHNS.

As amostras de biomssa e biocarvão foram pesadas $(2-2,5 \mathrm{mg}) \mathrm{em}$ balança analítica. No interior do equipamento, ocorre a combustão em uma atmosfera de oxigênio puro, os gases resultantes foram quantificados em um detector TCD (detector de condutividade térmica). Comparando os valores com curvas de calibração, obtida com os elementos padrão, foi possível identificar o teor dos elementos $\mathrm{C}, \mathrm{H}, \mathrm{N}$ e $\mathrm{S}$ presentas nas amostras.

\subsection{4}

\section{Espectroscopia no Infravermelho}

A espectroscopia no infravermelho por transformada de Fourier (FTIR) gera um agregado de bandas de absorção. Essas bandas, são formadas pela capacidade uma amostra conseguir absorver radiação em um determinado comprimento de onda. 
A análise das bandas características de determinados grupos funcionais de uma molécula fornece, através de um simples exame do espectro e consulta a tabelas de dados, um conjunto valioso de informações sobre a estrutura da molécula.

O experimento foi realizado utilizando um equipamento PerkinElmer 89282. Biomassa e biocarvão foram analisados na faixa de 4000 a $500 \mathrm{~cm}^{-1}$ para a identificação dos grupos funcionais presentes. 0,002 g de amostra foi misturada com $0,028 \mathrm{~g}$ de brometo de potássio $(\mathrm{KBr})$ e prensada para formar pastilhas translúcidas que foram utilizadas no equipamento.

\subsection{5}

\section{Termogravimetria}

A termogravimetria (TG) identifica a decomposição térmica de um material, por meio da diferença de massa, através de uma longa faixa de temperatura com aquecimento contínuo. Dessa forma é possível identificar as faixas de decomposição da celulose, hemicelulose e lignina, assim como quantificar o material residual restante.

A análise termogravimétrica da biomassa e do biocarvão foi realizada nas dependências do Departamento de Engenharia Química e de Materiais da PUC-Rio, utilizando 25,0 mg de amostra em um equipamento TG Netzsch STA 449 F3 Jupter, na faixa de temperatura de $20{ }^{\circ} \mathrm{C}$ a $1000{ }^{\circ} \mathrm{C}$, em atmosfera inerte de nitrogênio, sob fluxo de $20 \mathrm{~mL} \cdot \mathrm{min}^{-1}$ e taxa de aquecimento de 10 ${ }^{\circ} \mathrm{C} \cdot \mathrm{min}^{-1}$.

\subsection{6}

\section{Microscopia Eletrônica de Varredura}

A análise por Microscopia Eletrônica de Varredura (MEV), foi realizada para a observação de imagens tridimensionais de alta resolução da superfície da amostra, permitindo assim observar suas características morfológicas.

O sistema EDS (Energy Dispersive System) acoplado ao MEV foi utilizado como uma técnica analítica qualitativa dos elementos em fração mássica, fornecendo uma estimativa de componentes inorgânicos presentes na amostra.

O experimento foi conduzido em parceria com o Centro de Tecnologia Mineral (CETEM). Uma pequena quantidade da amostra foi recoberta com prata para aumentar sua condutividade. A análise de MEV foi realizada em um equipamento Hitach TM3030Plus, utilizando voltagem de aceleração do feixe de elétrons de $15,0 \mathrm{kV}$. 


\subsection{7}

\section{Cromatografia gasosa}

A cromatografia gasosa acoplada a um espectrômetro de massas (CGMS) é uma técnica de separação e identificação dos compostos presentes em uma mistura. No cromatógrafo ocorre a separação dos compostos de acordo com suas propriedades físicas e químicas e suas interações com a coluna de separação (fase estacionária). Já no espectrômetro de massas os componentes são convertidas em íons em fase gasosa, que são separados e identificados de acordo com sua razão massa/carga.

O experimento foi conduzido em parceria com a Firjan - SENAI Rio. O bio-óleo foi diluído em acetona na proporção de 1,8/100 (v/v) e filtrado em poros de $0,45 \mu \mathrm{m}$ para a remoção de particulados. O equipamento utilizado foi um cromatógrafo, acoplado a um espectrômetro de massa, Shimadzu GCMS QP2010, com coluna capilar foi RTX - 5MS de dimensões de $30 \mathrm{~m}$ x 0,25 mm, onde $1 \mu \mathrm{L}$ de amostra foi injetada. A rampa de aquecimento começou em $60{ }^{\circ} \mathrm{C}$, mantida por $2 \mathrm{~min}$, aquecimento de $10{ }^{\circ} \mathrm{C} \cdot \mathrm{min}^{-1}$ até $120{ }^{\circ} \mathrm{C}$, aquecimento de $8^{\circ} \mathrm{C} \cdot \mathrm{min}^{-1}$ até $280{ }^{\circ} \mathrm{C}$, mantida por $5 \mathrm{~min}$, seguindo metodologia semelhante a adotada por Nazari et al. (2015) [59]. Os componentes foram identificados através da biblioteca NIST 2011. 
5

\section{Resultados e Discussões}

\section{1}

\section{Caracterização do bagaço de malte}

\subsection{1}

\section{Teor de umidade}

O teor de umidade do bagaço de malte, logo após a utilização para a produção de cerveja, apresentou um valor de $91,3 \pm 1,8 \%$. Este resultado está de acordo com a referência analisada [11], que classifica o teor de umidade no malte em valores acima de $80 \%$, sendo assim, uma boa fonte de matéria-prima para utilizar na HTL.

\subsection{2}

\section{Análise granulométrica}

A Figura 5.1 indica os resultados da análise granulométrica do bagaço de malte.

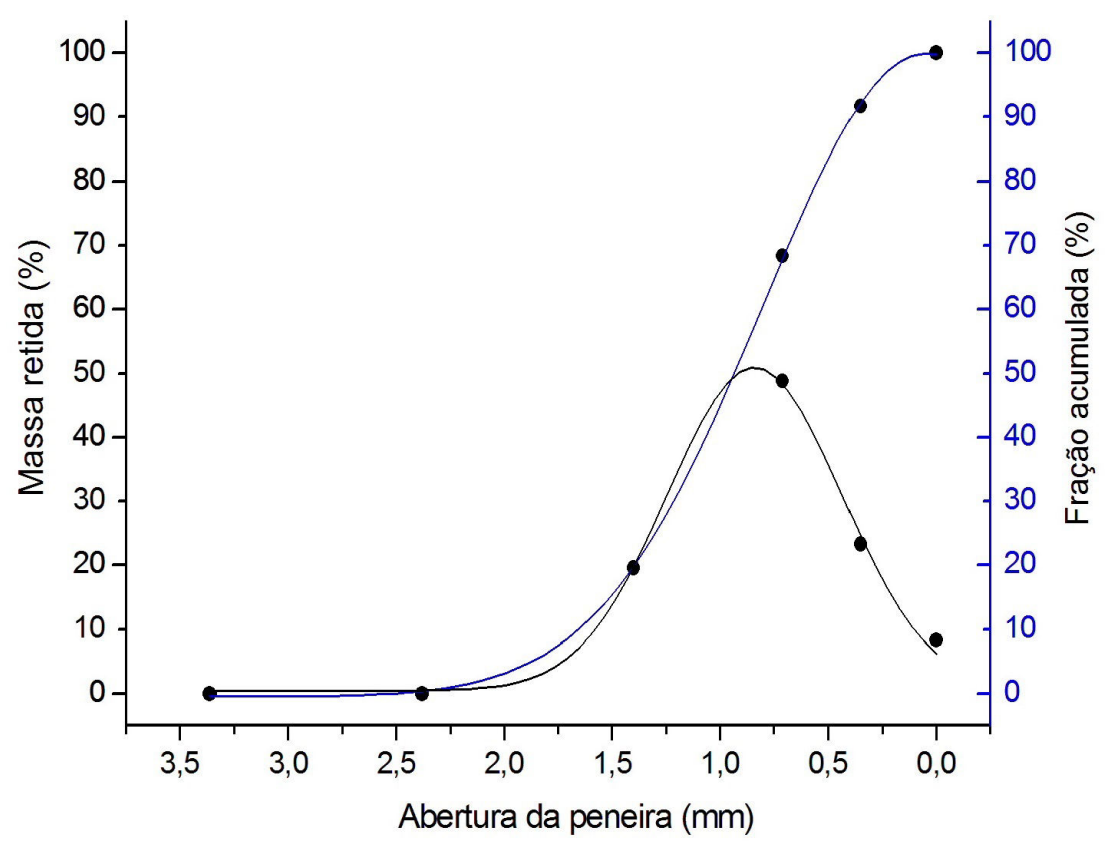

Figura 5.1: Análise granulométrica 
Através dos resultados obtidos, é possível perceber que as partículas de malte são relativamente pequenas, não apresentando diâmetro maior que 2,38 $\mathrm{mm}$. Isto acontece pois na etapa de preparação do mosto ocorre a moagem dos grãos para facilitar a extração dos açúcares, como indicado no fluxograma da Figura 3.5. Desta forma, o bagaço de malte apresentou tamanho de partícula na faixa ideal para a liquefação [42].

\subsection{3}

\section{Densidade e porosidade}

As densidades e porosidade do bagaço de malte, calculados com a Equação (4-3), são representados na Tabela 5.1.

Tabela 5.1: Densidade e porosidade

\begin{tabular}{ccc}
\hline $\begin{array}{c}\rho_{\text {aparente }} \\
\left(\mathrm{g} . \mathrm{cm}^{-3}\right)\end{array}$ & $\begin{array}{c}\rho_{\text {relativa }} \\
\left(\mathrm{g} \cdot \mathrm{cm}^{-3}\right)\end{array}$ & $\begin{array}{c}\epsilon \\
(\%)\end{array}$ \\
\hline 0,26 & 1,67 & 85,0 \\
\hline
\end{tabular}

Observa-se que a densidade aparente apresenta um valor característico de biomassas vegetais como cascas de café, bagaço de milho e eucalípto [60]. O valor baixo indica que há pouca massa disponível, podendo ser um fator prejudicial na geração de energia. Fato que pode ser observado devido a alta densidade relativa e volume de poros.

\subsection{4}

\section{Composição da biomassa}

Biomassas vegetais apresentam teores de extrativos, celulose, hemicelulose e lignina em sua composição que são passíveis de serem degradados em processos de conversão térmica. Também apresentam umidade residual, mesmo após secagem e cinzas, que são componentes inorgânicos residuais. A Tabela 5.2 indica os valores destes componentes no bagaço de malte.

Tabela 5.2: Composição da biomassa

\begin{tabular}{cccccc}
\hline $\begin{array}{c}\text { Umidade } \\
(\%)\end{array}$ & $\begin{array}{c}\text { Celulose } \\
(\%)\end{array}$ & $\begin{array}{c}\text { Hemicelulose } \\
(\%)\end{array}$ & $\begin{array}{c}\text { Lignina } \\
(\%)\end{array}$ & $\begin{array}{c}\text { Extrativos } \\
(\%)\end{array}$ & $\begin{array}{c}\text { Cinzas } \\
(\%)\end{array}$ \\
\hline 8,82 & 42,41 & 22,26 & 22,45 & $<0,05$ & 4,03 \\
\hline
\end{tabular}

A pequena quantidade de umidade presente no bagaço de malte, mesmo após a secagem, depende da forma de armazenamento, transporte e umidade relativa local. Celulose, hemicelulose e lignina estão de acordo com a literatura para biomassas lignocelulósicas [21]. O alto teor de lignina representa uma 
barreira física em processos de hidrólise, porém, em processos de conversão térmica pode gerar maiores quantidades de hidrocarbonetos aromáticos e compostos fenólicos após sua decomposição [25].

O baixo teor de extrativos pode indicar que grande parte desse componente foi extraído no processo cervejeiro. Já as cinzas indicam que o bagaço de malte ainda apresenta compostos inorgânicos que não são passíveis de conversão durante a HTL.

\section{2}

\section{Liquefação hidrotérmica}

\subsection{1}

\section{Modelagem cinética}

Na modelagem cinética, o processo de HTL descrito no capítulo de Materiais e Métodos foi realizado com temperaturas de 120, 140, 160 e $180{ }^{\circ} \mathrm{C}$ e elevados tempos de residência variando entre 10 e 210 minutos. Garantindo assim que toda a biomassa capaz de degradar passe ao estado líquido (estado intermediário ou de transição), sem haver formação de produtos da HTL.

Através dos experimentos, notou-se que a reação de degradação da biomassa depende dessas duas variáveis. A relação entre a razão de liquefação, utilizando a Equação (4-4) e o tempo de residência, em diferentes temperaturas, são apresentados na Figura 5.2.

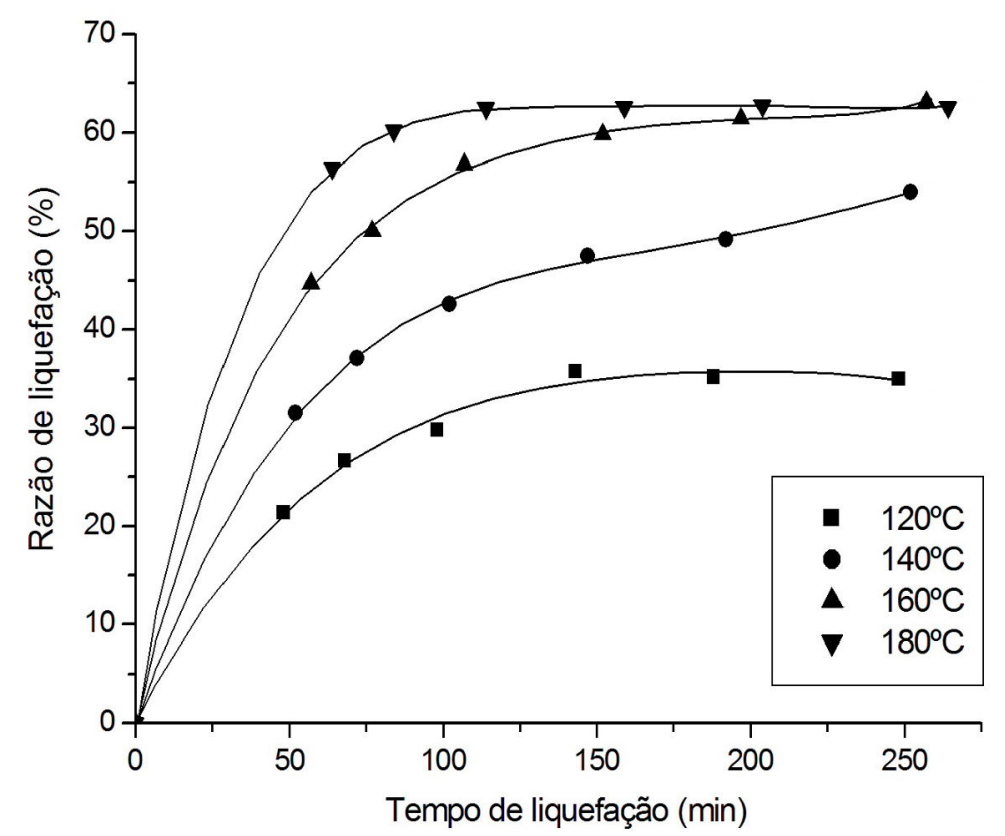

Figura 5.2: Efeito da temperatura na razão de liquefação

De acordo com a Figura 5.2 é possível verificar que as razões de liquefação aumentam com o tempo de reação até alcançarem um valor máximo, onde toda 
a biomassa capaz de se liquefazer nessas condições, já reagiu, assim, a razão se estabiliza para tempos mais longos, indicando que a reação de degradação foi completa para determinada temperatura. Resultado semelhante aos reportados por Alma (2004) e Yan (2010) et al. [55,61].

Através da linearização da modelagem cinética utilizando o logaritmo da razão de liquefação por tempo (taxa de liquefação), e o conteúdo residual, Equação (4-8), foi possível traçar o gráfico representado na Figura 5.3.

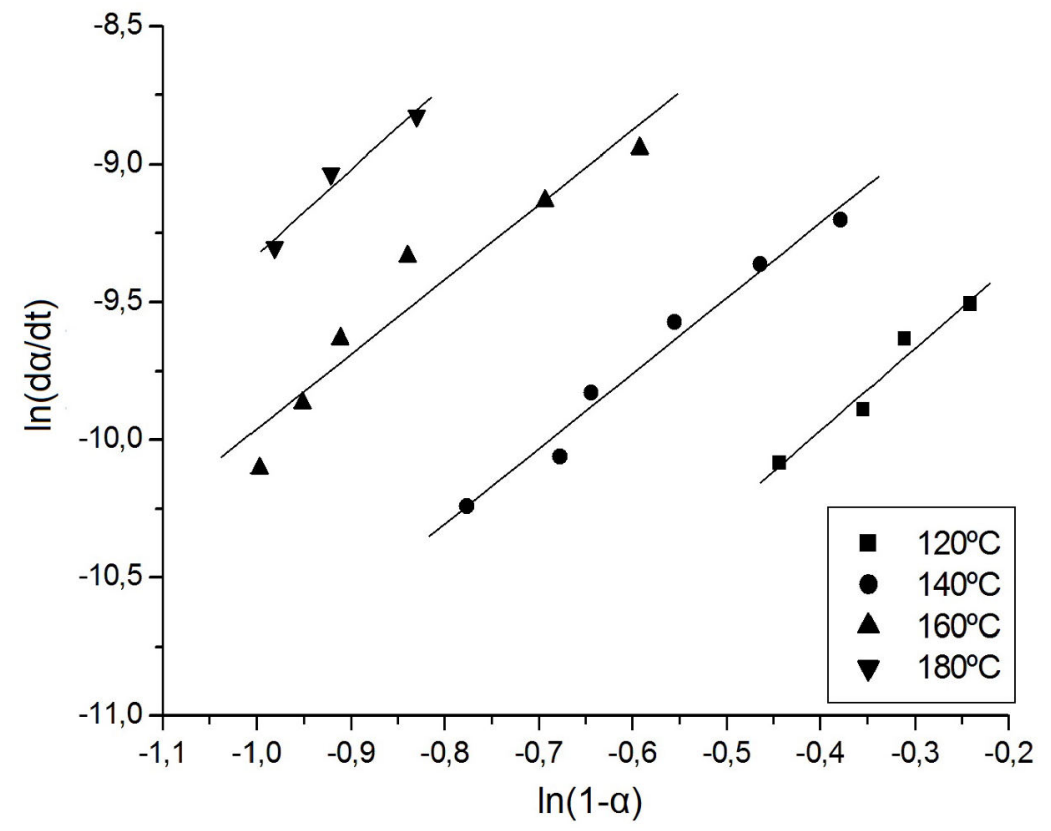

Figura 5.3: Relação entre a taxa de liquefação e o conteúdo residual

Para os pontos da modelagem cinética foram levados em consideração apenas os tempos em que a reação ainda não havia chegado ao fim, assim, alguns pontos de estabilização para temperatura de $120{ }^{\circ} \mathrm{C}$ e $180{ }^{\circ} \mathrm{C}$ foram descartados. O ajuste linear obtido no gráfico da Equação (4-8) comprova a relação entre a taxa da reação e conteúdo residual em diferentes temperaturas. Dessa forma, o modelo cinético adotado pode ser usado para determinar a constante de velocidade e a ordem aparente da reação, como observado na Tabela 5.3.

Tabela 5.3: Variáveis cinéticas do processo em diferentes temperaturas

\begin{tabular}{ccccc}
\hline $\begin{array}{c}\text { Temperatura } \\
\left({ }^{\circ} \mathrm{C}\right)\end{array}$ & $\begin{array}{c}\text { (Inclinação) } \\
\text { Ordem aparente } \\
\text { da reação }(n)\end{array}$ & $\begin{array}{c}\text { (Interseção) } \\
\ln (k)\end{array}$ & $\begin{array}{c}\text { Constante } \\
\text { de velocidade } \\
k .10^{-4}\left(\mathrm{~s}^{-1}\right)\end{array}$ & $\mathrm{R}^{2}$ \\
\hline 120 & 2,98 & $-8,77$ & 1,55 & 0,958 \\
140 & 2,73 & $-8,12$ & 2,98 & 0,987 \\
160 & 2,71 & $-7,25$ & 7,09 & 0,922 \\
180 & 3,08 & $-6,25$ & 19,27 & 0,962 \\
\hline
\end{tabular}


Através dos resultados nota-se que a constante de velocidade aumentou com a elevação da temperatura, gerando uma maior liquefação da biomassa. A ordem aparente da reação em torno de três comprova que a liquefação da biomassa envolve várias outras reações simultâneas muito complexas [55].

Utilizando os dados da Tabela 5.3 e a Equação (4-9), é possível identificar a relação linear entre a constante de velocidade $k$ e a temperatura de cada experimento, como representado na Figura 5.4.

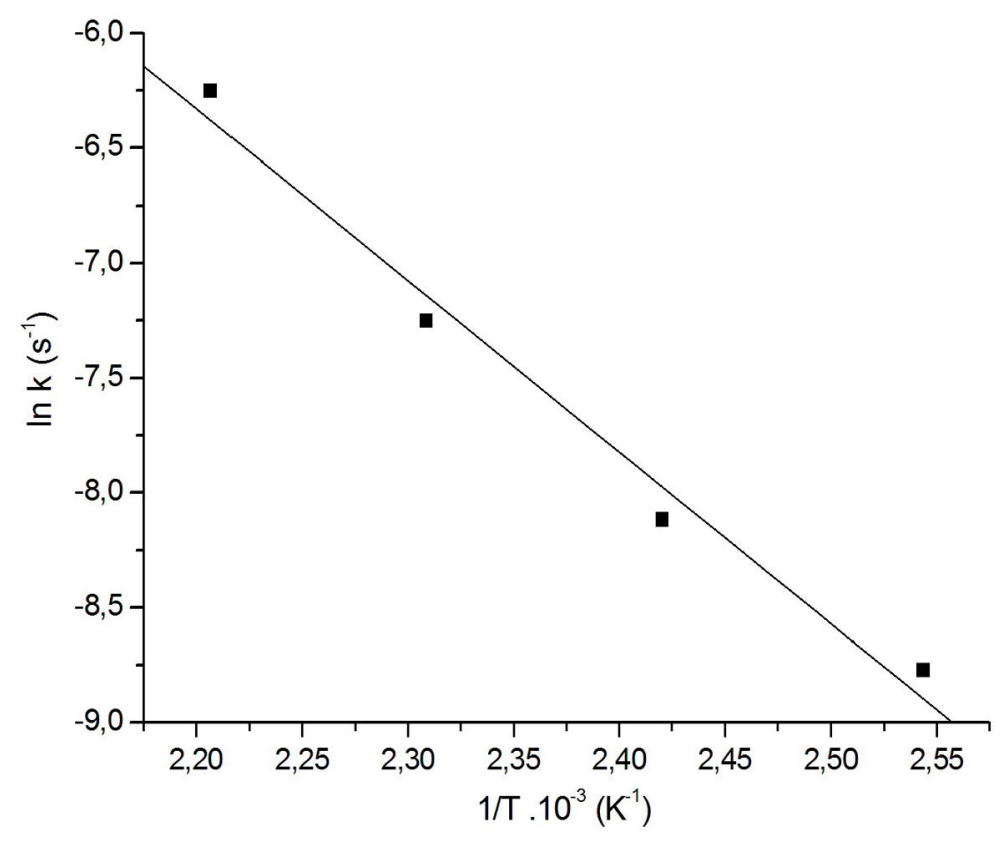

Figura 5.4: Equação de Arrhenius linearizada

O valor do fator de frequência $A$ é obtido utilizando o ponto em que a reta cruza o eixo das ordenadas, e a energia de ativação $E a$ é encontrada pela inclinação da reta. A Tabela 5.4 representa os resultados finais obtidos para a modelagem cinética da liquefação do bagaço de malte.

Tabela 5.4: Parâmetros cinéticos da reação de liquefação

\begin{tabular}{cccccc}
\hline $\begin{array}{c}\text { Ordem } \\
\text { aparente } \\
\text { média }(n)\end{array}$ & $\begin{array}{c}\text { Interseção) } \\
\ln (A)\end{array}$ & $\begin{array}{c}\text { Fator de } \\
\text { frequência } \\
A .10^{4}\left(\mathrm{~s}^{-1}\right)\end{array}$ & $\begin{array}{c}\text { (Inclinação) } \\
-E a / R\end{array}$ & $\begin{array}{c}\text { Energia de } \\
\text { ativação } \\
E a\left(\mathrm{~kJ}_{\text {mol }}{ }^{-1}\right)\end{array}$ & $\mathrm{R}^{2}$ \\
\hline 2,88 & 10,09 & 2,41 & -7467 & 62,08 & 0,982 \\
\hline
\end{tabular}

A combinação de todos os elementos cinéticos indicam como uma reação química pode acontecer. Ao estudar estes parâmetros é possível entender como os produtos químicos são convertidos e identificar os mecanismos de controle da reação [56]. O ajuste linear, sem mudança de inclinação da reta, representado na Figura 5.4 indica que não houve alteração no mecanismo da reação, além disso, grande sensibilidade da constante de velocidade com o 
aumento da temperatura e valores de energia de ativação elevados, como o obtido experimentalmente, indicam que o mecanismo da reação é de controle químico [62].

Alguns modelos cinéticos semelhantes são relatados na literatura. Acemioglu (2002) e Alma (2004) et al. estudaram a cinética de degradação de biomassa, em presença de fenol e ácido sulfúrico, como solventes, segundo uma reação bimolecular de segunda ordem e lei de Arrhenius [61,63]. Yan et al. (2010) estudaram a cinética de biomassa em polietilenoglicol levando em conta a lei de Arrhenius e o conteúdo residual do processo, sendo possivel determinar a ordem experimental da reação entre outras variáveis [55]. Zhang et al. (2014), estudaram a cinética de degradação em polietilenoglicol levando em consideração o teor final de celulose, hemicelulose e lignina [64].

A comparação entre os principais parâmetros cinéticos dos trabalhos descritos e os resultados obtidos para o bagaço de malte são apresentados na Tabela 5.5.

Tabela 5.5: Comparação de resultados da modelagem cinética

\begin{tabular}{ccccc}
\hline Biomassa & $\begin{array}{c}\text { Ordem média } \\
\text { aparente }\end{array}$ & $\begin{array}{c}A \\
\left(\mathrm{~s}^{-1}\right)\end{array}$ & $\begin{array}{c}E a \\
\left(\mathrm{~kJ} . \mathrm{mol}^{-1}\right)\end{array}$ & Referência \\
\hline $\begin{array}{c}\text { Resíduo de } \\
\text { madeira }\end{array}$ & $\begin{array}{c}\text { Não definida } \\
\text { experimentalmente }\end{array}$ & $\begin{array}{c}\text { Não definido } \\
\text { experimentalmente }\end{array}$ & 68,50 & {$[61]$} \\
$\begin{array}{c}\text { Talo de } \\
\text { milho }\end{array}$ & 2,40 & $8,80.10^{5}$ & 73,60 & {$[55]$} \\
$\begin{array}{c}\text { Madeira } \\
\begin{array}{c}\text { Bagaço de } \\
\text { malte }\end{array}\end{array}$ & 2,99 & $7,17.10^{4}$ & 63,93 & {$[64]$} \\
\hline
\end{tabular}

É possível observar que os resultados do bagaço de malte apresentaram valores muito próximos dos obtidos pelos demais pesquisadores, apesar da matéria-prima e do solvente utilizado na liquefação terem sido diferentes. Isto demonstra que estas duas variáveis apresentam pequeno efeito na etapa inicial de liquefação. Além disso, todas as ordens experimentais da reação apresentaram valores próximos a 3 , demonstrando complexidade na degradação da biomassa em produtos liquefeitos. 


\section{2 .2}

\section{Termodinâmica via Teoria do Estado de Transição}

A termodinâmica adotada para o estudo, baseia-se na Teoria do Estado de Transição, pois refere-se apenas a primeira etapa do processo de HTL, correspondende a degradação da biomassa em produtos liquefeitos, sem haver formação de bio-óleo, biocarvão e demais produtos.

Através da equação de Eyring para o estado de transição, Equação (4-12), é possível determinar a variação da energia livre de Gibbs do estado de transição para cada faixa de temperatura utilizando a constante de velocidade $k$, obtida na modelagem cinética.

A variação da entalpia depende se a reação liquefação ocorre em solução ou em fase gasosa. Diversos pesquisadores discutiram este fato e concluíram que a fase da reação pode variar e é influenciada por diferentes condições de processo. Para solventes orgânicos como polietilenoglicol e fenol, em geral, a reação ocorre em fase gasosa, já para a água, presume-se que ocorra em solução. Neste trabalho, ambas as fases de reação foram adotadas para análise, tornando possível uma comparação entre os valores, assim, a entalpia do estado de transição foi definida pelas Equações (4-20) e (4-23). Por fim, através da Equação (4-25) foi possível obter a entropia do estado de transição.

A Tabela 5.6 indica os resultados dos parâmetros termodinâmicos nas temperaturas estudadas, onde "sol" indica os resultados para a reação ocorrendo em solução e "gas" para a reação em fase gasosa.

Tabela 5.6: Parâmetros termodinâmicos

\begin{tabular}{cccccc}
\hline $\begin{array}{c}\mathrm{T} \\
\left({ }^{\circ} \mathrm{C}\right)\end{array}$ & $\begin{array}{c}\Delta G^{*} \\
\left(\mathrm{~kJ} . \mathrm{mol}^{-1}\right)\end{array}$ & $\begin{array}{c}\Delta H_{\text {sol }}^{*} \\
\left(\mathrm{~kJ} . \mathrm{mol}^{-1}\right)\end{array}$ & $\begin{array}{c}\Delta H_{\text {gas }}^{*} \\
\left(\mathrm{~kJ} . \mathrm{mol}^{-1}\right)\end{array}$ & $\begin{array}{c}-\Delta S_{\text {sol }}^{*} \\
\left(\mathrm{~J} . \mathrm{mol}^{-1} \cdot \mathrm{K}^{-1}\right)\end{array}$ & $\begin{array}{c}-\Delta S_{\text {gas }}^{*} \\
\left(\mathrm{~J} . \mathrm{mol}^{-1} \cdot \mathrm{K}^{-1}\right)\end{array}$ \\
\hline 120 & 125,86 & 58,81 & 55,54 & 170,55 & 178,86 \\
140 & 130,19 & 58,65 & 55,21 & 173,17 & 181,48 \\
160 & 133,54 & 58,48 & 54,88 & 173,29 & 181,60 \\
180 & 136,11 & 58,31 & 54,55 & 171,69 & 180,00 \\
\hline
\end{tabular}

Pelos resultados termodinâmicos obtidos, nota-se que há pouca diferença entre os valores de entalpia e entropia para a reação ocorrendo em solução ou em fase gasosa. Isto ocorre devido ao alto valor da energia de ativação obtido, tornando a influência do termo R.T das Equações (4-20) e (4-23) muito pequena.

Também é possível identificar, pelos valores de energia livre de Gibbs e entalpia do estado de transição, que a degradação da biomassa em produtos líquefeitos é uma reação não-espontânea e endotérmica, ou seja, precisa receber calor externo para que a reação aconteça. 
Todos os pesquisadores, reportados anteriormente, que estudaram a parte termodinâmica do processo, também utilizaram a Teoria do Estado de Transição para a determinação da energia livre de Gibbs, entalpia e entropia. Os trabalhos tiveram a suposição que a reação somente ocorria em fase gasosa. Os resultados são comparados na Tabela 5.7.

Tabela 5.7: Comparação dos resultados termodinâmicos

\begin{tabular}{|c|c|c|c|c|}
\hline Biomassa & 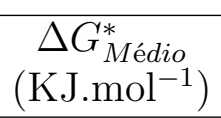 & $\begin{array}{c}\Delta H_{M \text { édio }}^{*} \\
\left(\mathrm{KJ}_{\mathrm{mol}}^{-1}\right)\end{array}$ & $\begin{array}{c}-\Delta S_{M}^{*} \text { édio } \\
\left(\mathrm{J} . m o l^{-1} \cdot \mathrm{K}^{-1}\right)\end{array}$ & Referência \\
\hline $\begin{array}{c}\text { Resíduo de } \\
\text { madeira }\end{array}$ & 112,49 & 7,15 & 278,62 & [63] \\
\hline $\begin{array}{l}\text { Resíduo de } \\
\text { madeira }\end{array}$ & 102,45 & 61,82 & 103,07 & [61] \\
\hline $\begin{array}{l}\text { Talo de } \\
\text { milho }\end{array}$ & 131,65 & 66,38 & 150,73 & {$[55]$} \\
\hline $\begin{array}{l}\text { Bagaço de } \\
\text { malte }\end{array}$ & 131,43 & 55,04 & 180,49 & $\begin{array}{l}\text { Próprio } \\
\text { autor }\end{array}$ \\
\hline
\end{tabular}

Através da comparação de resultados, nota-se que o bagaço de malte apresentou parâmetros termodinâmicos semelhantes a outras biomassas da literatura previamente estudadas, mostrando-se todos na mesma ordem de grandeza. A maior diferença, apresentada na referência [63] pode ter ocorrido devido a utilização de temperaturas mais baixas, entre 60 e $150{ }^{\circ} \mathrm{C}$, se comparada aos demais pesquisadores.

As pequenas diferenças em todos os valores comparados, podem ter ocorrido devido ao equipamento utilizado, o tipo de solvente do processo, faixa de temperatura adotada e a biomassa estudada, no entanto, como resultado final, todas foram caracterizadas como reações não-espontâneas e endotérmicas.

\section{2 .3}

\section{Rendimento e produtividade}

A HTL foi conduzida em três diferentes temperaturas para avaliar o rendimento na formação dos produtos. A menor temperatura, $250{ }^{\circ} \mathrm{C}$, foi escolhida por ser o final da faixa de carbonização e início da liquefação, segundo a literatura [43]. A temperatura mais alta, $300{ }^{\circ} \mathrm{C}$, foi adotada por ser a temperatura ótima de processo $[44,47,48]$, além de estar dentro da faixa de segurança do reator utilizado, uma vez que a pressão interna do sistema, 
gerada pela água, aumenta exponencialmente com a elevação da temperatura. A temperatura intermediária, $275{ }^{\circ} \mathrm{C}$, também foi utilizada para estudar a formação dos produtos, compreendendo uma faixa total de $50{ }^{\circ} \mathrm{C}$.

Tempos de residência curtos, 5 min, intermediários, 30 min e longos, 60 min, foram utilizados no estudo para verificar a formação de bio-óleo, biocarvão, produtos gasosos e produtos solúveis em água. Elevados tempos de residência não foram utilizados, pois priorizam principalmente a formação de gases.

Ao final do processo, não foi possível medir a quantidade de gás gerada individualmente, desta forma, o rendimento de produtos gasosos e produtos solúveis em água (psa) foram medidos juntos.

As Figuras 5.5, 5.6 e 5.7 representam os resultados de rendimento simultaneamente com a produtividade para os principais produtos de HTL, de acordo com o tempo de residência do processo.

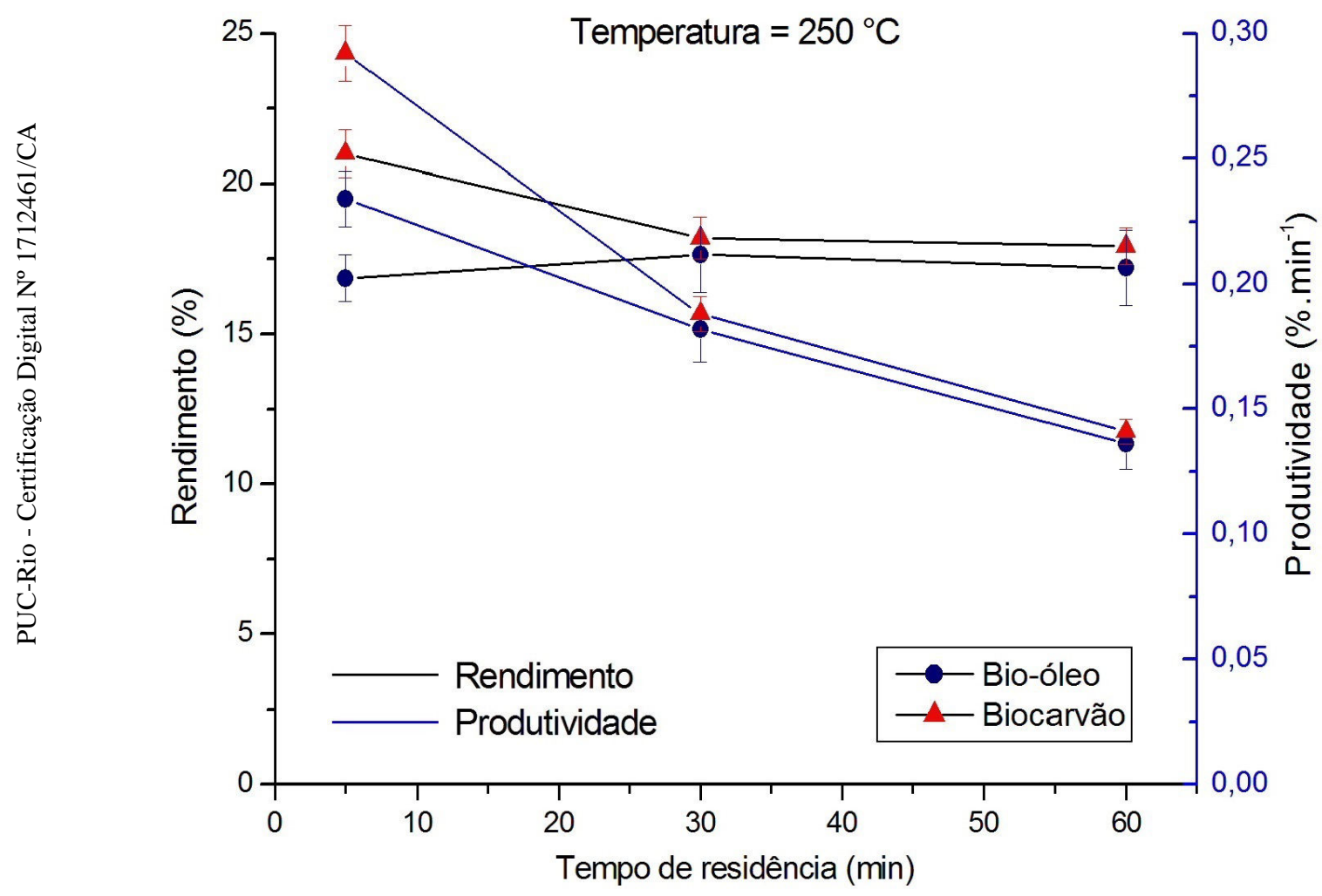

Figura 5.5: Rendimento e produtividade a $250{ }^{\circ} \mathrm{C}$ 


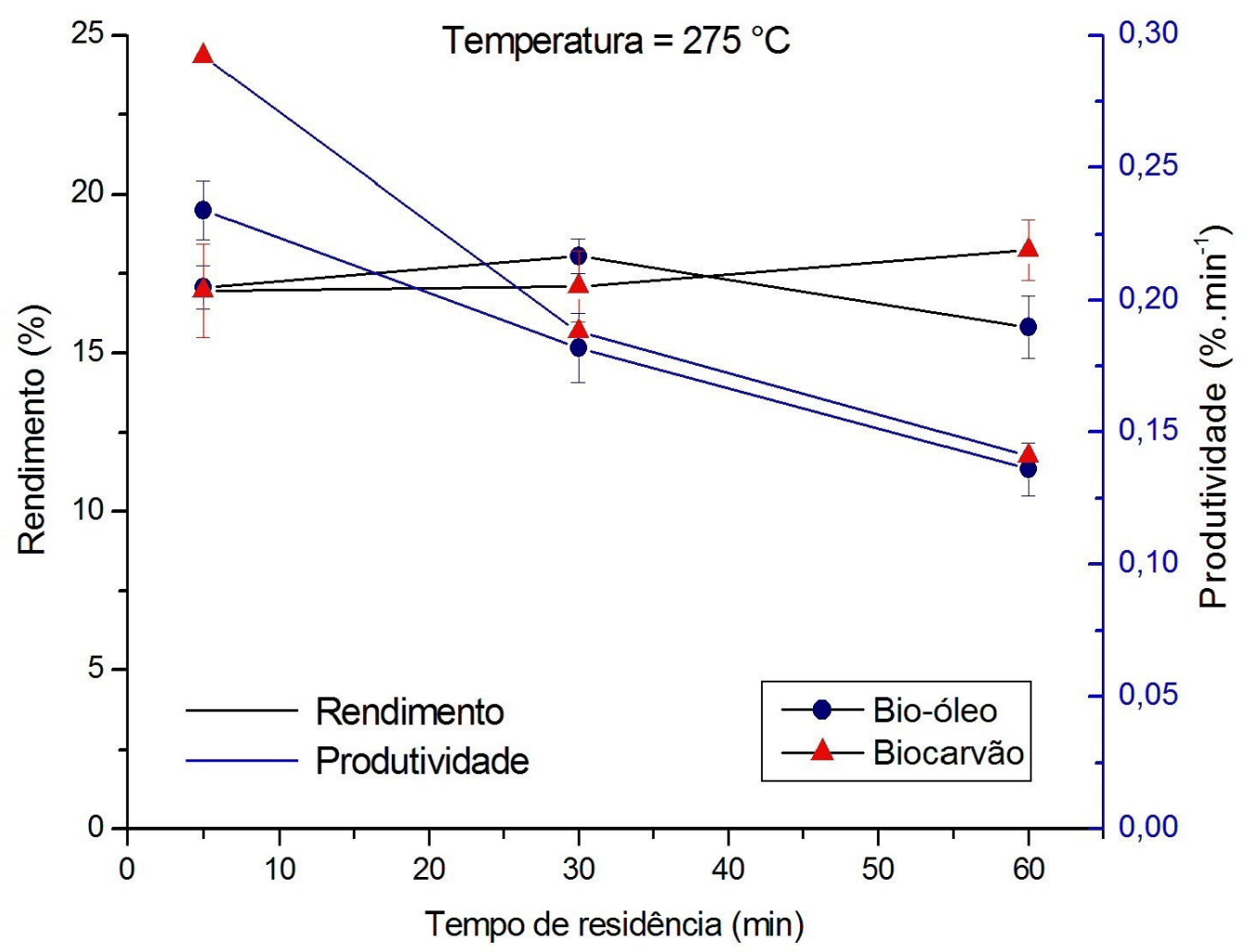

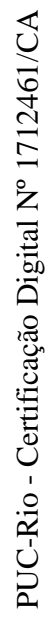

Figura 5.6: Rendimento e produtividade a $275{ }^{\circ} \mathrm{C}$

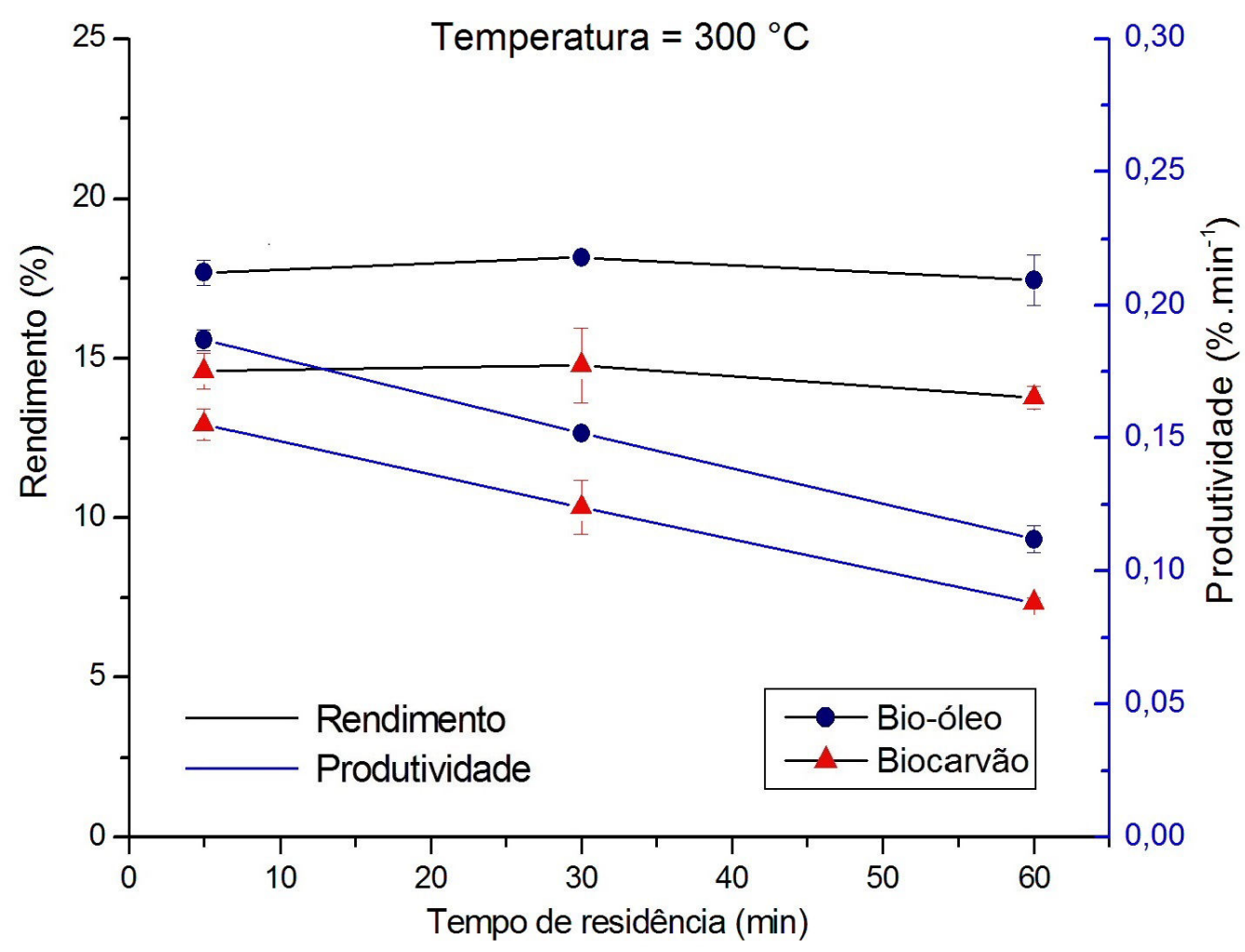

Figura 5.7: Rendimento e produtividade a $300{ }^{\circ} \mathrm{C}$ 
Observando apenas as linhas pretas (equivalentes ao rendimento de produtos), observa-se que os produtos gasosos juntos com psa, não representados graficamente, são responsáveis por mais de $60 \%$ do total de produtos formados, no entanto, estes apresentam dificuldades de armazenamento e transporte, além de menor interesse comercial. Assim, apenas o bio-óleo e o biocarvão foram os principais produtos de estudo.

Bio-óleo apresentou perfil de produção crescente, junto com o aumento da temperatura, levando em conta o mesmo tempo de residência, ou seja, para um mesmo tempo de residência, quanto maior a temperatura, maior foi o rendimento de bio-óleo. Este resultado está de acordo com o esperado, uma vez que a temperatura se aproxima da temperatura ótima de $300{ }^{\circ} \mathrm{C}$ reportada na literatura $[40,47]$.

Observando o perfil do rendimento de bio-óleo considerando uma mesma temperatura, observa-se que este começa um pouco mais baixo em 5 min, atinge o valor máximo em 30 min e decresce levemente ao chegar em $60 \mathrm{~min}$ em todos os casos. Isto ocorre, devido a conversão de bio-óleo em produtos gasosos em elevados tempos de residência. Novamente o resultado está dentro do perfil esperado já que alguns autores reportam 30 min como o tempo de maior rendimento [47].

O rendimento máximo de bio-óleo ocorreu em $300{ }^{\circ} \mathrm{C}$ com tempo de 30 min, atingindo um valor de $18,2 \%$ de conversão, porém apenas 2,8\% superior ao rendimento de 17,7\% em 5 min. Comparando estes valores com as referências apresentadas na Tabela 3.2, nota-se que se mantém próximo a demais biomassas, superando os rendimentos de madeira, eucalipto e alga e ficando atrás de pinheiro e esterco.

O perfil do biocarvão se mostrou diferente. A $250{ }^{\circ} \mathrm{C}$ obteve-se os maiores rendimentos do material, alcançando $21,0 \%$ de rendimento em 5 min. Este resultado ocorre pois essa temperatura está dentro do limite da faixa denominada carbonização hidrotérmica, no qual se prioriza a formação de biocarvão.

Em $275{ }^{\circ} \mathrm{C}$ o biocarvão mostrou comportamento oposto ao bio-óleo, aumentando em quanto o rendimento do líquido diminuia. Já em $300{ }^{\circ} \mathrm{C}$, os comportamentos foram semelhantes, obtendo $14,6 \%$ de rendimento em 5 min. Isto indica que durante a formação dos produtos de HTL, não há uma relação específica entre formação de biocarvão e bio-óleo.

Para o cálculo da produtividade foi levado em conta o tempo total de processo, que em reatores não contínuos, consiste no tempo de carga somado ao tempo de rodar uma nova batelada. Os tempos de processo, em min, são apresentados na Tabela 5.8. 
Tabela 5.8: Tempos de processo (min)

\begin{tabular}{cccc}
\hline & $250{ }^{\circ} \mathrm{C}$ & $275{ }^{\circ} \mathrm{C}$ & $300{ }^{\circ} \mathrm{C}$ \\
\hline $\mathrm{t}_{\text {carga }}$ & 5 & 5 & 5 \\
$\mathrm{t}_{\text {purga }}$ & 7 & 7 & 7 \\
$\mathrm{t}_{\text {aquecimento }}$ & 34 & 39 & 46 \\
$\mathrm{t}_{\text {residência }}$ & $5-30-60$ & $5-30-60$ & $5-30-60$ \\
$\mathrm{t}_{\text {resfriamento }+ \text { abertura }}$ & 21 & 26 & 31 \\
$\mathrm{t}_{\text {total }}$ & $72-97-127$ & $82-107-137$ & $94-119-149$ \\
\hline
\end{tabular}

Pela Tabela 5.8 é possível observar a diferença entre os tempos de aquecimento e resfriamento com o aumento da temperatura, fazendo que o processo HTL demore mais em $300{ }^{\circ} \mathrm{C}$. Também observa-se que apesar do tempo de residência no interior do reator ser pequeno, a realização de uma batelada total demora mais de $1 \mathrm{~h}$ além desse tempo para ser concluída.

Observando as linhas azuis (equivalente ao eixo da produtividade) das Figuras 5.5, 5.6 e 5.7, é possível identificar que todos os pontos de maior produtividade foram obtidos em $5 \mathrm{~min}$. Isto ocorre pois apesar do rendimento ser levemente inferior, o tempo total de processo mais rápido compensa este fato, gerando maior formação de produtos em um mesmo intervalo de tempo. Desta forma, o tempo de 5 min foi adotado como o tempo ótimo de processo.

A Figura 5.8 representa os principais produtos gerados na HTL.
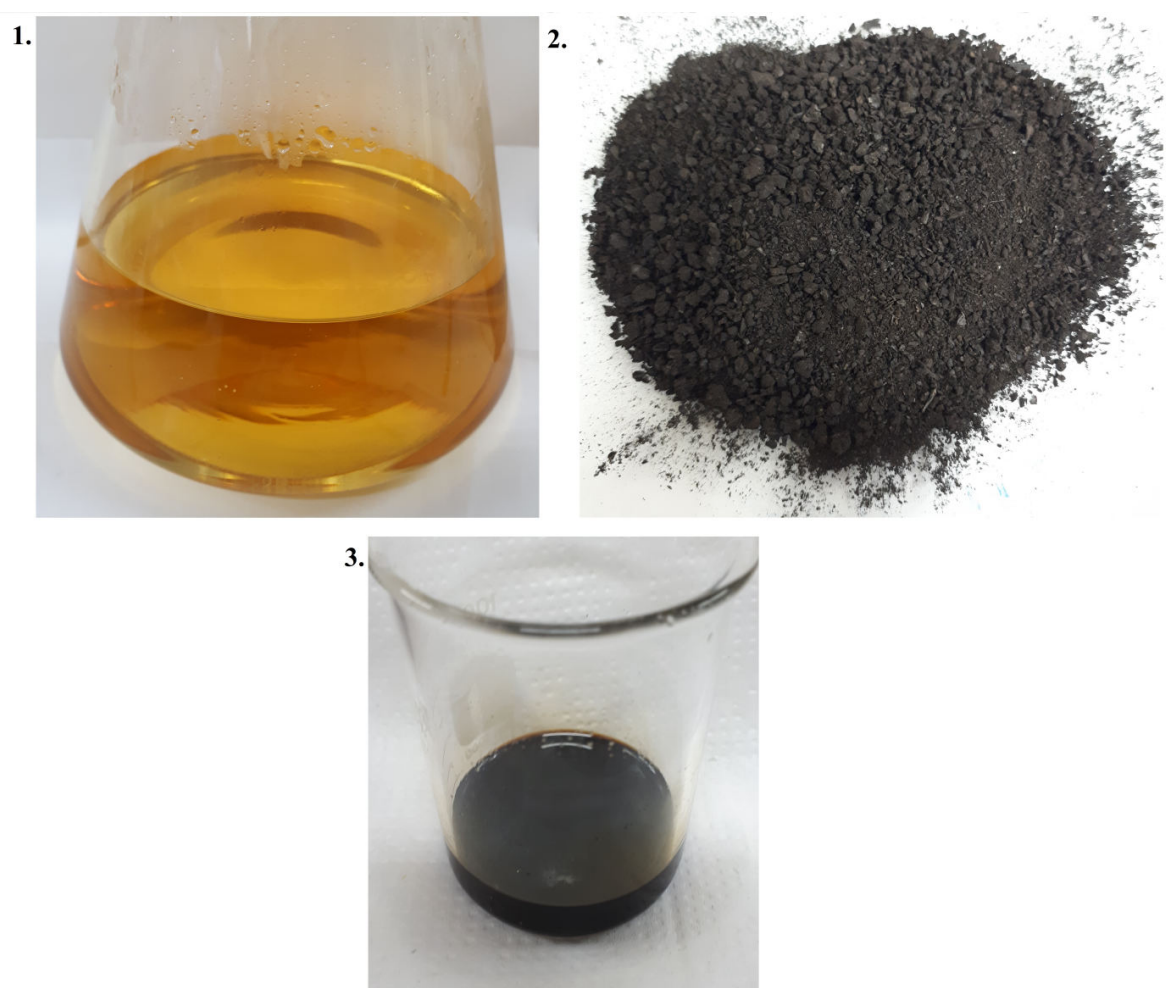

Figura 5.8: Produtos gerados na HTL: 1. produtos solúveis em água, 2. biocarvão, 3. bio-óleo 


\section{3}

\section{Comparação da biomassa e dos produtos gerados}

\subsection{1}

\section{Poder calorífico superior}

O poder calorífico superior refere-se a quantidade de energia disponível, em uma unidade de massa, que é liberada ao final da combustão completa de um material. Assim, quanto maior o valor do PCS, maior será seu potencial de uso como biocombustível.

Inicialmente, foi determinado o PCS do bagaço de malte antes da realização do processo HTL, utilizando a bomba calorimétrica, obtendo-se o valor de 19,48 MJ.kg-1.

A comparação com outras biomassas convencionais são apresentadas na Tabela 5.9.

Tabela 5.9: Poder calorífico superior de diferentes biomassas

\begin{tabular}{ccc}
\hline Biomassa & PCS $\left({\left.\mathrm{MJ} . \mathrm{kg}^{-1}\right)}^{-}\right.$ & Referência \\
\hline Casca de pinheiro & 20,24 & {$[65]$} \\
Palha de milho & 17,42 & {$[51]$} \\
Palha de trigo & 17,11 & {$[66]$} \\
Bagaço de cana-de-açúcar & 16,36 & {$[51]$} \\
Bagaço de malte & 19,06 & {$[66]$} \\
Bagaço de malte & 19,48 & Próprio autor \\
\hline
\end{tabular}

É possível observar que o bagaço de malte apresenta um PCS cerca de $10 \%$ superior a biomassas convencionais utilizadas em processos de combustão e cogeração de energia como palha de milho e bagaço de cana-de-açúcar, ficando apenas atrás de cascas de madeiras, como a casca de pinheiro. O resultado indica que o bagaço de malte, antes da HTL, já apresenta potencial para ser utilizado diretamente nesses processos energéticos.

Em trabalho publicado por Linan-Montes e demais pesquisadores, também foi analisado o PCS do bagaço de malte, obtendo o valor de 19,06 MJ. $\mathrm{kg}^{-1}$ [66]. A pequena variação, inferior a $2,5 \%$ para o resultado obtido neste trabalho, indica que os valores são iguais, demonstrando que não há significativa diferença em relação ao tipo de malte e a mistura de grãos utilizada.

Após a realização da HTL nas diferentes faixas de temperaturas e tempos de residência estudados, foi determinado o PCS de cada um dos principais produtos formados, como representados no gráfico da Figura 5.9. 


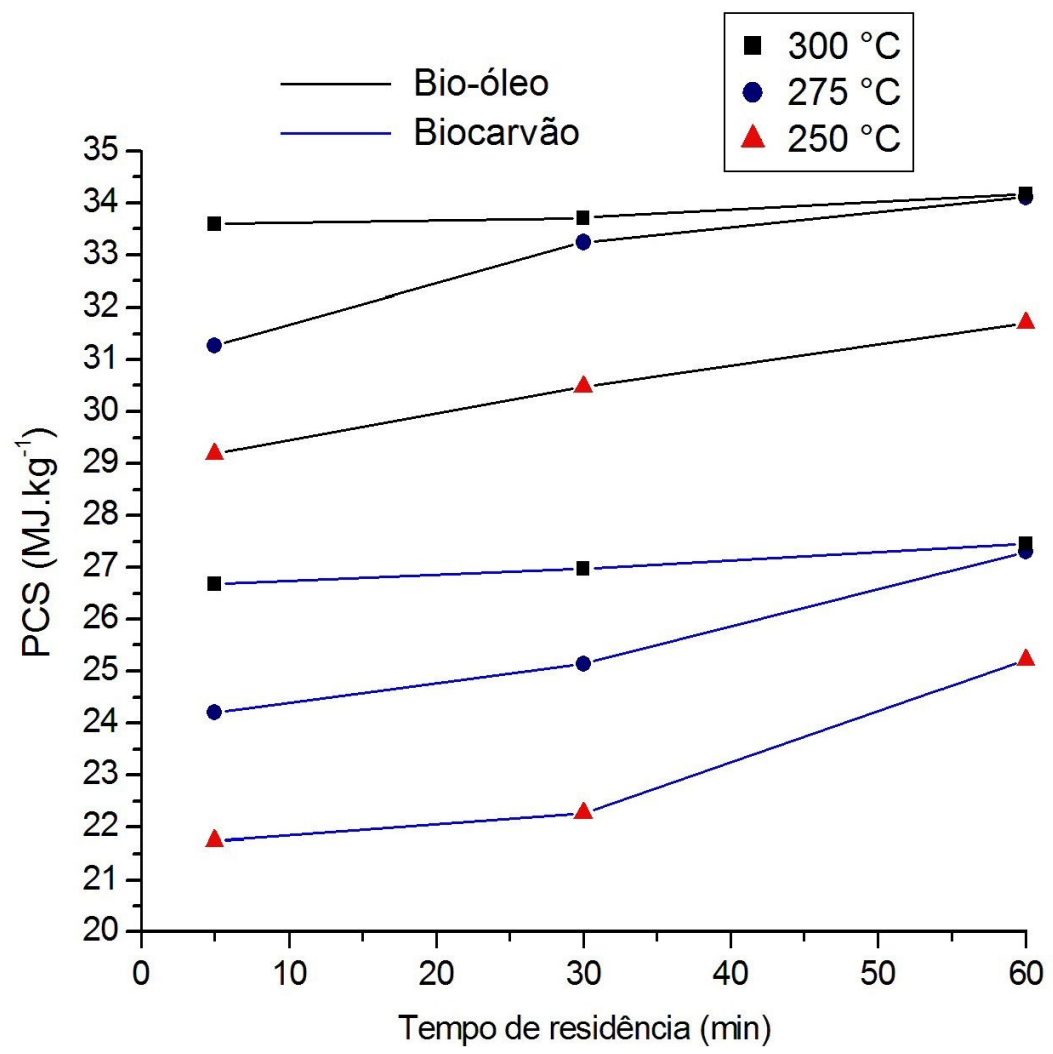

Figura 5.9: Poder calorífico superior dos produtos da HTL

É possível notar que o bio-óleo sempre apresenta maior PCS em relação ao biocarvão. Além disso, todos os valores se mantiveram crescentes ao longo do tempo dentro da mesma faixa de temperatura. Comparando diferentes temperaturas, dentro do mesmo tempo de residência, percebe-se que maiores temperaturas geram produtos com maior valor de PCS. Desta forma, os maiores valores foram obtidos na maior temperatura, $300{ }^{\circ} \mathrm{C}$, e no maior tempo de residência, 60 min, gerando um bio-óleo e um biocarvão com 34,17 e 27,45 $\mathrm{MJ} . \mathrm{kg}^{-1}$ respectivamente.

No entanto, levando em conta a produtividade do processo, no qual o tempo de residência ótimo foi de 5 min, obteve-se, para a melhor temperatura $\left(300{ }^{\circ} \mathrm{C}\right)$, um bio-óleo e um biocarvão com 33,58 e 26,69 MJ.kg ${ }^{-1}$ respectivamente, representando um valor apenas 1,69\% inferior para o bio-óleo e 2,76\% inferior para o biocarvão obtidos em $60 \mathrm{~min}$. Desta forma, conclui-se que a temperatura de $300{ }^{\circ} \mathrm{C}$ com o tempo de residência de 5 min são as condições ótimas de operação da HTL.

Através da comparação da biomassa de bagaço de malte inicial com o biocarvão após a HTL, foi obtido um aumento no PCS de 37,0\%, ampliando sua capacidade de aplicação como potencial biocombustível. A Tabela 5.10 mostra a comparação do biocarvão obtido com demais resultados da literatura, também obtidos por processos de termoconversão em condições similares, e 
combustíveis sólidos convencionais.

Tabela 5.10: Comparação do PCS do biocarvão

\begin{tabular}{ccc}
\hline Biomassa produtora do biocarvão & PCS $\left({\left.\mathrm{MJ} \cdot \mathrm{kg}^{-1}\right)}\right.$ & Referência \\
\hline Fibra de coco & 29,40 & {$[67]$} \\
Folha de eucalipto & 28,70 & {$[67]$} \\
Bagaço de cana-de-açúcar & 24,57 & {$[68]$} \\
Palha de milho & 21,00 & {$[69]$} \\
Bagaço de malte & 26,69 & Próprio autor \\
\hline Combustível sólido convencional & & \\
\hline Carvão mineral & 23,97 & {$[51]$} \\
Coque & 29,87 & {$[51]$} \\
\hline
\end{tabular}

O biocarvão obtido apresentou um valor intermediário quando comparado com outros biocarvões reportados na literatura. Já a comparação com combustíveis sólidos convencionais, indica um PCS 11,4\% superior ao carvão mineral tradicional e 10,7\% inferior ao coque, um dos melhores combustíveis sólidos disponíveis.

O bio-óleo produzido também foi comparado com a literatura e combustíveis tradicionais, representados na Tabela 5.11.

Tabela 5.11: Comparação do PCS do bio-óleo

\begin{tabular}{ccc}
\hline Biomassa produtora do bio-óleo & PCS $\left(\mathrm{MJ.kg}^{-1}\right)$ & Referência \\
\hline Esterco de vaca & 35,53 & {$[41]$} \\
Microalgas & $34,50-35,70$ & {$[70]$} \\
Resíduos de madeira & 29,00 & {$[59]$} \\
Bagaço de cana-de-açúcar & 26,80 & {$[71]$} \\
Bagaço de malte & 33,58 & Próprio autor \\
\hline Combustível líquido convencional & & \\
\hline Biodiesel & 40,17 & {$[51]$} \\
Diesel & 45,77 & {$[51]$} \\
Gasolina & 46,54 & {$[51]$} \\
\hline
\end{tabular}

Assim como o biocarvão, o bio-óleo também apresentou um valor intermediário de PCS comparado a outras fontes de biomassa. Levando em conta os principais combustíveis líquidos convencionais, o bio-óleo gerado apresentou um valor 16,4\%,27,8\%,26,6\% inferior ao biodiesel, gasolina e diesel respectivamente. Dessa forma, apesar do elevado potencial energético, o bio-óleo obtido diretamente como produto da HTL, sem passar por nenhum outro processo de acabamento ou conversão, ainda apresentou significativa defasagem em relação a combustíveis tradicionais para ser empregado como potencial produtor de energia renovável. 


\subsection{2}

\section{Análise imediata}

A análise imediata do bagaço do malte inicial e do biocarvão produzido na HTL foi realizada com a finalidade de identificar os principais componentes, e como o processo térmico afeta as composições dos materiais, sendo apresentada na Tabela 5.12.

Tabela 5.12: Análise imediata da biomassa e do biocarvão

\begin{tabular}{ccccc}
\hline Material & $\begin{array}{c}\text { Teor de } \\
\text { Umidade }(\%)\end{array}$ & $\begin{array}{c}\text { Teor de material } \\
\text { volátil }(\%)\end{array}$ & $\begin{array}{c}\text { Teor de carbono } \\
\text { fixo }(\%)\end{array}$ & $\begin{array}{c}\text { Teor de } \\
\text { cinzas }(\%)\end{array}$ \\
\hline Biomassa & 8,82 & 70,18 & 16,97 & 4,03 \\
Biocarvão & 5,68 & 36,74 & 55,36 & 2,22 \\
\hline
\end{tabular}

Observa-se que mesmo após a secagem, ambos os materiais apresentam baixo teor de umidade, devido as condições de armazenamento e umidade relativa local. Quanto maior o valor de umidade presente na biomassa, mais energia é necessária para dar ignição ao processo de queima, ou seja, mais energia é requerida para vaporizar a água e menos energia então é fornecida para a reação endotérmica [72]. Desta forma, o baixo teor de umidade presente em ambos os materiais pode ter influenciado negativamente no valor final do PCS.

O material volátil também interfere na ignição, quanto maior o teor de voláteis maior será a reatividade e, consequentemente, a facilidade de queima da biomassa. Alto teor de material volátil gera uma queima rápida do material, no entanto, gerando um menor valor de PCS. Já o carbono fixo, com valores inversamente proporcionais ao teor de volátil, apresentam uma queima mais lenta, liberando constantemente calor ao longo de maiores intervalos de tempo, gerando assim um maior PCS [72,73].

O processo HTL foi responsável pela retirada de parte do material volátil e formação de mais carbono fixo, assim, a biomassa, apresentou uma rápida queima porém um PCS inferior ao do biocarvão produzido.

O teor de cinzas representa os componentes inorgânicos presentes no material. Valores baixos indicam que parte da biomassa pode ser convertida em produtos de HTL, uma vez que as cinzas permanecem constantes e não são responsáveis pela formação de produtos.

O teor de cinzas do biocarvão, inferior a biomassa, se deve ao fato de que parte do material inorgânico pode ter ficado impregnado no reator ou se perdido durante a extração Soxhlet. 


\subsection{3}

\section{Análise elementar}

Através da análise elementar - CHNS foi possível identificar os principais elementos químicos presentes na biomassa e no biocarvão, representados na Tabela 5.13. O teor de oxigênio foi determinado pela diferença dos demais valores $[74,75]$.

Tabela 5.13: Análise elementar da biomassa e do biocarvão

\begin{tabular}{cccccccc}
\hline Material & $\mathrm{C}(\%)$ & $\mathrm{H}(\%)$ & $\mathrm{N}(\%)$ & $\mathrm{S}(\%)$ & $\mathrm{O}(\%)$ & $\mathrm{C} / \mathrm{H}$ & $\mathrm{O} / \mathrm{H}$ \\
\hline Biomassa & 44,81 & 6,33 & 4,65 & $<0,3$ & 44,21 & 7,08 & 6,98 \\
Biocarvão & 67,44 & 5,12 & 4,16 & $<0,3$ & 23,28 & 13,17 & 4,55 \\
\hline
\end{tabular}

Observa-se que ambos os materiais não apresentaram teor de enxofre detectável pelo equipamento na composição, indicando que não há contaminação aparente por este elemento.

A porcentagem de carbono aumentou no material após o processo de HTL, enquanto a porcentagem de oxigênio foi reduzida. Isto indica que parte de componentes orgânicos com alto teor de oxigênio, como os carboidratos e compostos fenólicos presentes na estrutura lignocelulósica da biomassa, foram utilizados na formação do bio-óleo e dos demais subprodutos, enquanto o biocarvão foi produzido principalmente a partir de hidrocarbonetos com baixo teor de oxigênio.

O aumento significativo da relação $\mathrm{C} / \mathrm{H}$ e a diminuição do teor de oxigênio na HTL é um bom indicador do processo de carbonização, uma vez que este processo ocorre com a liberação de compostos voláteis ricos em oxigênio e hidrogênio. Além disso, o aumento na relação $\mathrm{C} / \mathrm{H}$ indica um aumento no teor de compostos aromáticos presentes no biocarvão, devido ao reagrupamento molecular [75].

Também é reportada uma relação positiva entre o PCS e a razão $\mathrm{C} / \mathrm{H}$, assim, maiores valores da razão $\mathrm{C} / \mathrm{H}$ indicam um maior PCS, conforme obtido em resultados anteriores [76].

Para a relação $\mathrm{O} / \mathrm{H}$ é reportada uma influência negativa no PCS. O oxigênio presente nas cinzas, principalmente na forma de óxidos e fosfatos, não participa da combustão apesar de ser contabilizado na massa do combustível sujeito a queima. Desta forma, materias com maior razão $\mathrm{O} / \mathrm{H}$ apresentam PCS inferiores [76]. 


\subsection{4}

\section{Espectroscopia no Infravermelho}

Para identificar os possíveis sítios de ligação existentes na biomassa e no biocarvão, foi realizada a espectroscopia no infravermelho com transformada de Fourier (FTIR).

A Figura 5.10 representa o gráfico do FTIR e os principais picos de comprimento de onda identificados.

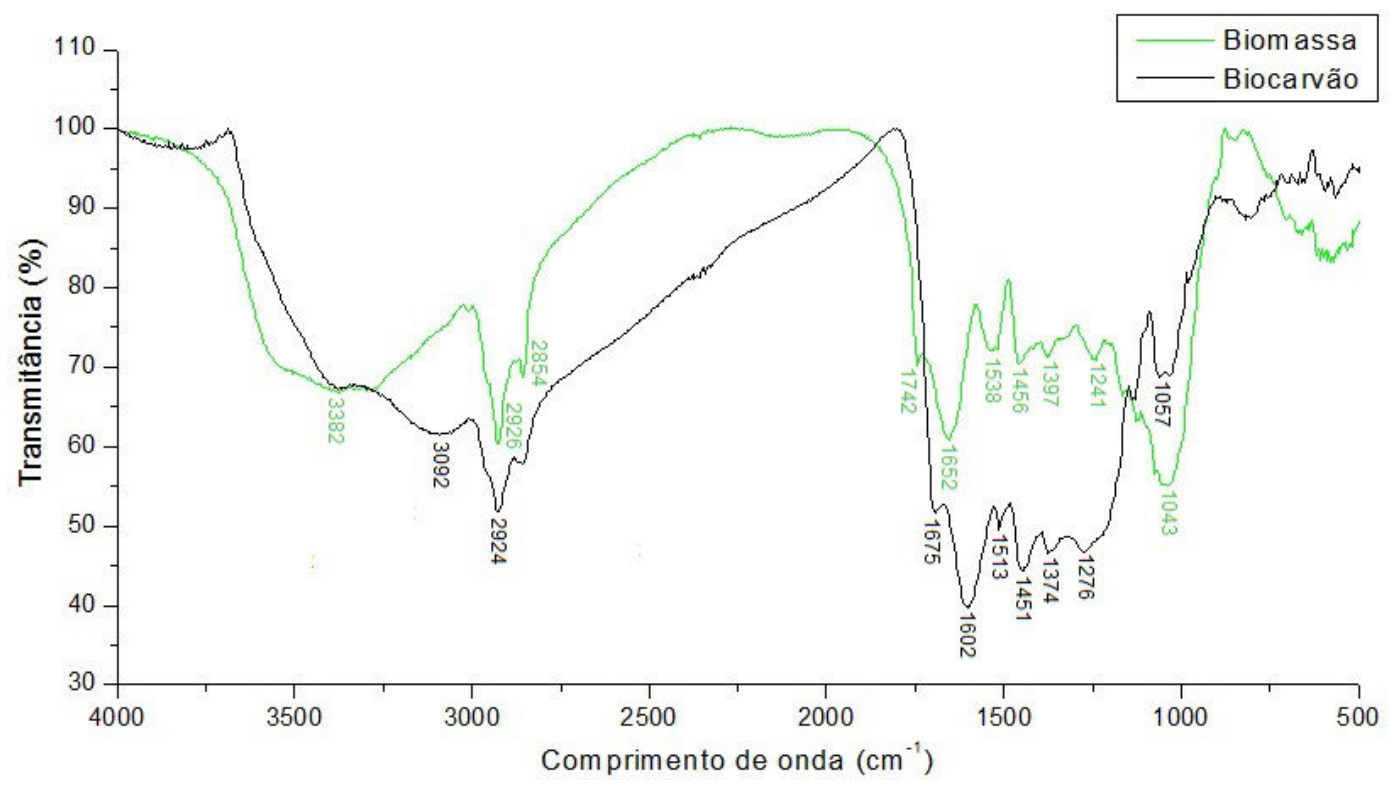

Figura 5.10: Espectroscopia no Infravermelho da biomassa e do biocarvão

A banda em $3382 \mathrm{~cm}^{-1}$ é responsável pela presença de grupamentos com a função hidroxila $(-\mathrm{OH})$, sendo característica de álcoois e fenóis, encontrados na celulose e hemicelulose. A identificação desta banda apenas na biomassa, indica que estes compostos foram degradados durante a HTL para a formação dos demais produtos, não permanecendo presentes no biocarvão. Já banda de 3092 $\mathrm{cm}^{-1}$, identificada apenas no biocarvão, indica a presença de cicloalcanos ou compostos aromáticos formados após a HTL por recombinação molecular [77].

As bandas obtidas a 2926 e $2854 \mathrm{~cm}^{-1}$ para a biomassa e $2924 \mathrm{~cm}^{-1}$ para o biocarvão são formadas por vibrações de alongamento e encurtamento de compostos com metileno (carbono divalente $-\mathrm{CH}_{2^{-}}$) presente em alcanos [77].

Os picos gerados entre 1750 e $1650 \mathrm{~cm}^{-1}$ indicam vibração axial de ligações $\mathrm{C}=\mathrm{O}$, podendo representar aldeídos, cetonas e ácidos carboxílicos presentes em ambas as amostras. [78].

Bandas entre 1600 e $1200 \mathrm{~cm}^{-1}$ são relacionadas a vibração da ligação dupla entre carbonos de compostos aromáticos e deformações angulares de ligações C-H [77], sendo observada uma grande variedade destes compostos em ambas as amostras analisadas. 
Os dois últimos picos, a 1043 e $1057 \mathrm{~cm}^{-1}$ para biomassa e biocarvão respectivamente, são formados por vibração axial da ligação C-O, indicando a presença de álcoois [77].

Através da análise do FTIR foi possível observar uma significativa diferença entre a composição da biomassa inicial e do biocarvão produzido pela HTL. A ausência de picos idênticos indica que os compostos lignocelulósicos sofreram grandes alterações ao longo do processo, sendo reestruturados em novos componentes químicos.

\subsection{5}

\section{Termogravimetria}

A termogravimetria foi realizada para identificar o comportamento da decomposição térmica da biomassa e do biocarvão, ao longo da temperatura, representados no gráfico da Figura 5.11.
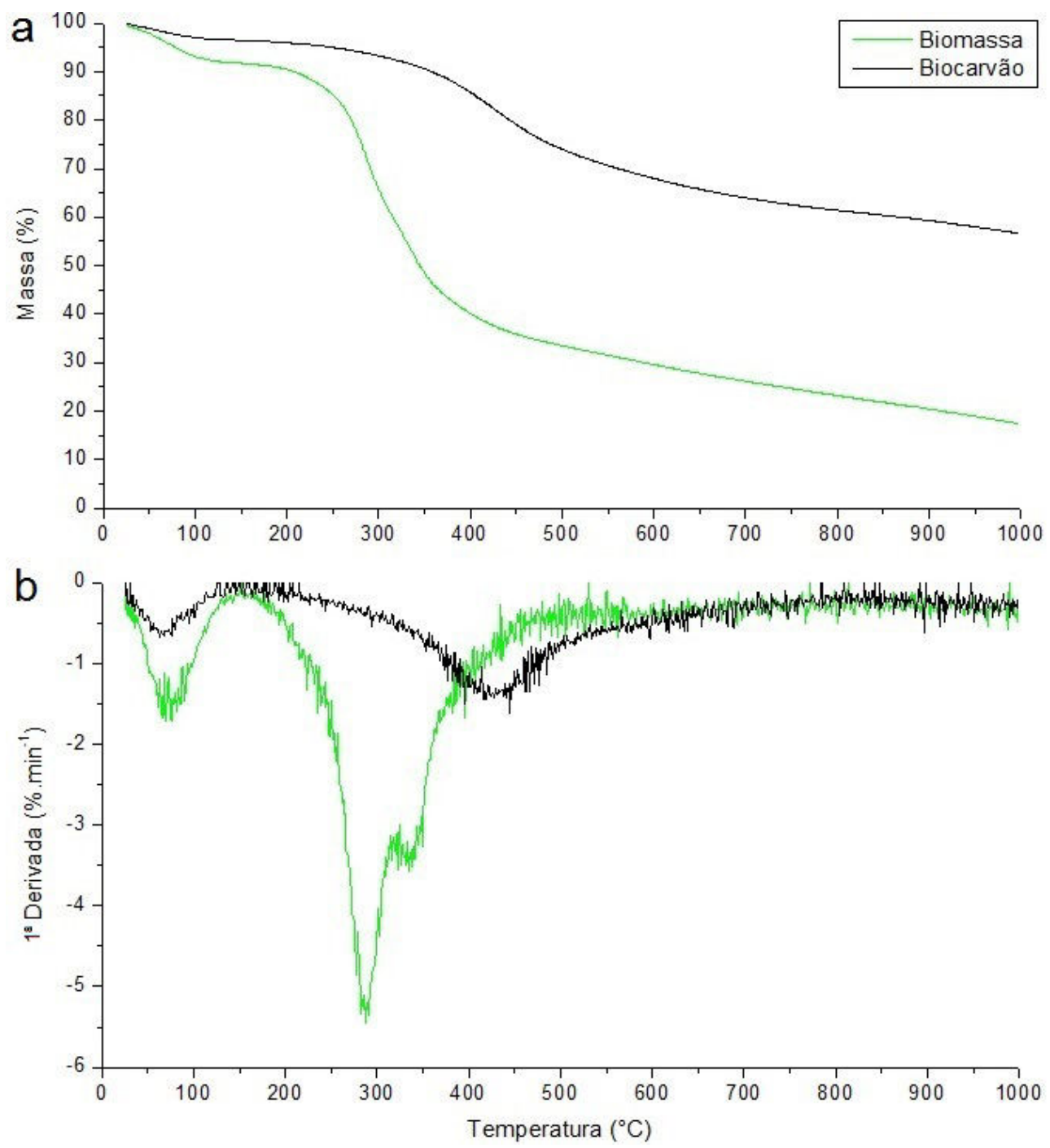

Figura 5.11: Termogravimetria da biomassa e do biocarvão. a: porcentagem mássica; b: derivada mássica 
A Figura 5.11 (a) representa a porcentagem de massa que é perdida ao longo do aumento da temperatura, já a Figura 5.11 (b) representa a $1^{\text {a }}$ derivada desse valor, indicando as faixas de maior degradação dos materiais.

A primeira zona de perda de massa, observada para ambos os materiais, ocorre até os $100{ }^{\circ} \mathrm{C}$ e representa a eliminação da água presente [25]. Observase por ambos os gráficos que a perda de massa na biomassa é maior do que no biocarvão, indicando maior evaporação da água e, consequentemente, maior umidade, assim como foi comprovado no resultado da análise imediata.

A segunda e terceira zonas de perda de massa do bagaço de malte são claramente identificadas no gráfico da $1^{\text {a }}$ derivada. A duas faixas representam a degradação da hemicelulose e da celulose respectivamente entre 200 e $400{ }^{\circ} \mathrm{C}$ [79]. No caso do biocarvão é identificada apenas uma zona indo aproximadamente de 300 a $600{ }^{\circ} \mathrm{C}$. A ausência de picos e baixa porcentagem de perda de massa inferiores a $300{ }^{\circ} \mathrm{C}$ gera indícios de que grande parte da hemicelulose foi degradada e convertida em produtos durante a HTL.

O segundo pico, observado no biocarvão, devido a ampla faixa de temperatura, indica picos sobrepostos de degradação da celulose e lignina. Não é observado um pico claro de degradação da lignina para a biomassa, acima de $400{ }^{\circ} \mathrm{C}$, isto ocorre pois a degradação deste material é contínua e lenta, no entanto, através da perda de massa, é possível identificar esta degradação ocorrendo até a temperatura final.

Através da análise no TG, verificou-se que 82,6\% da biomassa é passível de degradação por processos de termoconversão, restando apenas 17,4\% de material final. Este resultado é próximo ao obtido pela análise imediata ao somar o teor de cinzas e carbono fixo (21,0\% somados). Da mesma forma é observada apenas 43,3\% de degradação do biocarvão e 56,7\% de material restante, próximos aos $57,6 \%$ obtidos na análise imediata, indicando confiabilidade nos resultados. Além disso, analisando tais valores precebe-se que o carbono fixo não é convertido em produtos através de processos térmicos, sendo o principal responsável pelo poder calorífico dos materiais.

Através do resultado de degradação do biocarvão e descontando o teor de umidade, percebe-se que aproximadamente apenas 37,6\% do material deixou de ser convertido em produtos durante a HTL. Tal fato pode ter ocorrido devido as condições de operação adotadas. No entanto, comparando os valores finais de biomassa e biocarvão e a altura do picos gerados pelo gráfico da derivada, concluíu-se que a HTL promove uma conversão quase completa da hemicelulose e altas conversões de celulose e lignina. 


\subsection{6}

\section{Microscopia Eletrônica de Varredura}

A caracterização por MEV do bagaço de malte foi realizada para a análise da morfologia e composição elementar através do sistema EDS. A Figura 5.12 representa as imagens obtidas em diferentes ampliações.
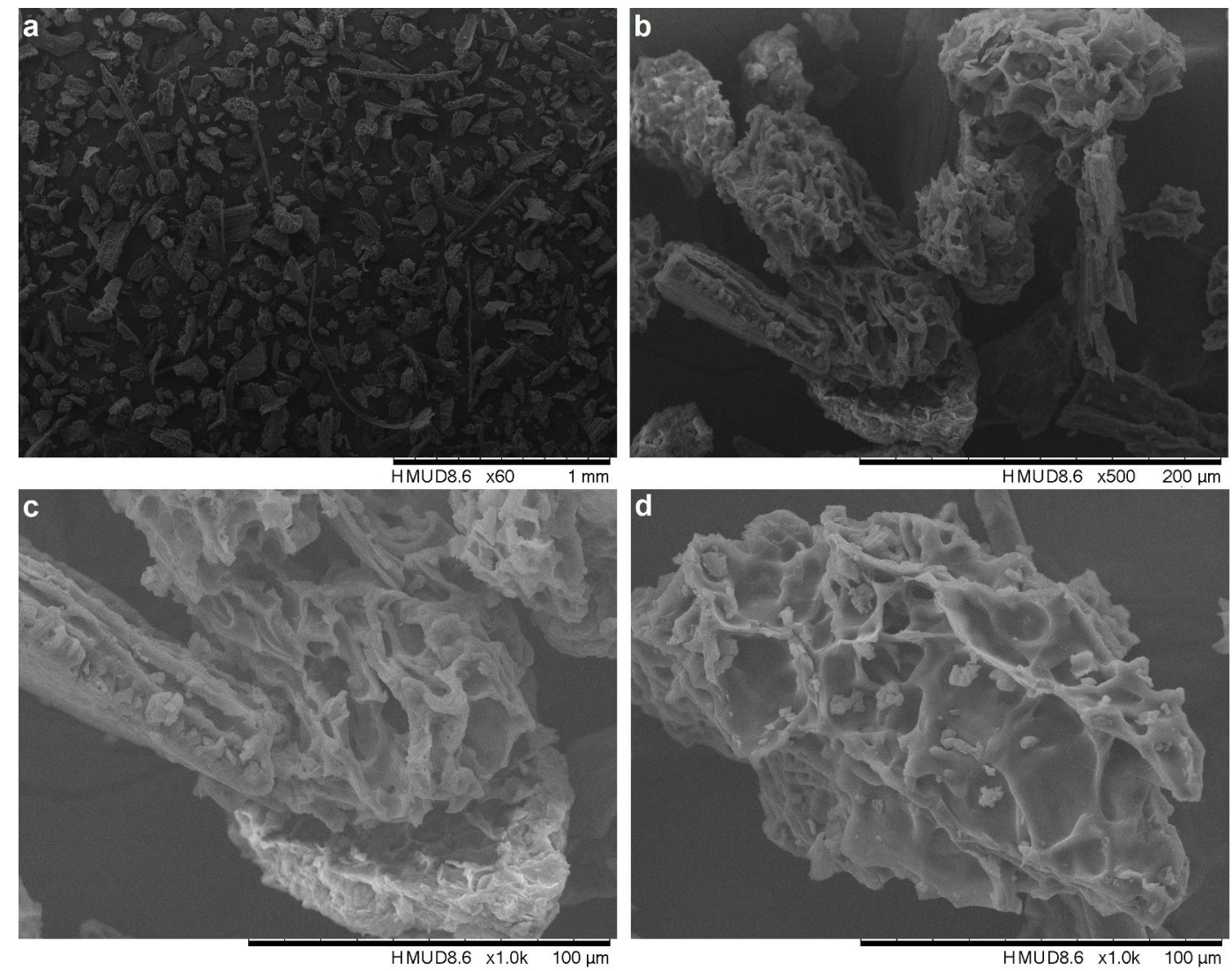

Figura 5.12: Visão da biomassa no MEV. a: visão geral com ampliação de 60x; b: particulados com apliação de 500x; c,d: partículas com ampliação de 1000x

Observa-se, pelas diferentes imagens, que a biomassa é composta por um aglomerado de pequenas partículas aparentemente rugosas, cercada de poros e sem estruturas bem definidas, gerando indícios de elevada área superficial, responsável por intensificar processos de degradação térmica como a HTL. $\mathrm{Na}$ imagem (a), identifica-se apenas alguns filamentos longos, característico de biomassas fibrosas como coco e cana-de-açúcar, no entanto, grãos como o bagaço de malte apresentam poucas estruturas alongadas. Na imagem (d), observa-se pequenas partículas com formato esférico aglomeradas, podendo representar algumas impurezas presentes. Dessa forma, foi realizada a análise EDS para esta identificação.

O sistema EDS indicou a presença de potássio e fósforo, no entanto, esses elementos não são considerados contaminantes, uma vez que são característicos 
de fertilizantes usados em processo de adubação que podem ter permanecido na biomassa

O MEV para o biocarvão produzido é representado na Figura 5.13.
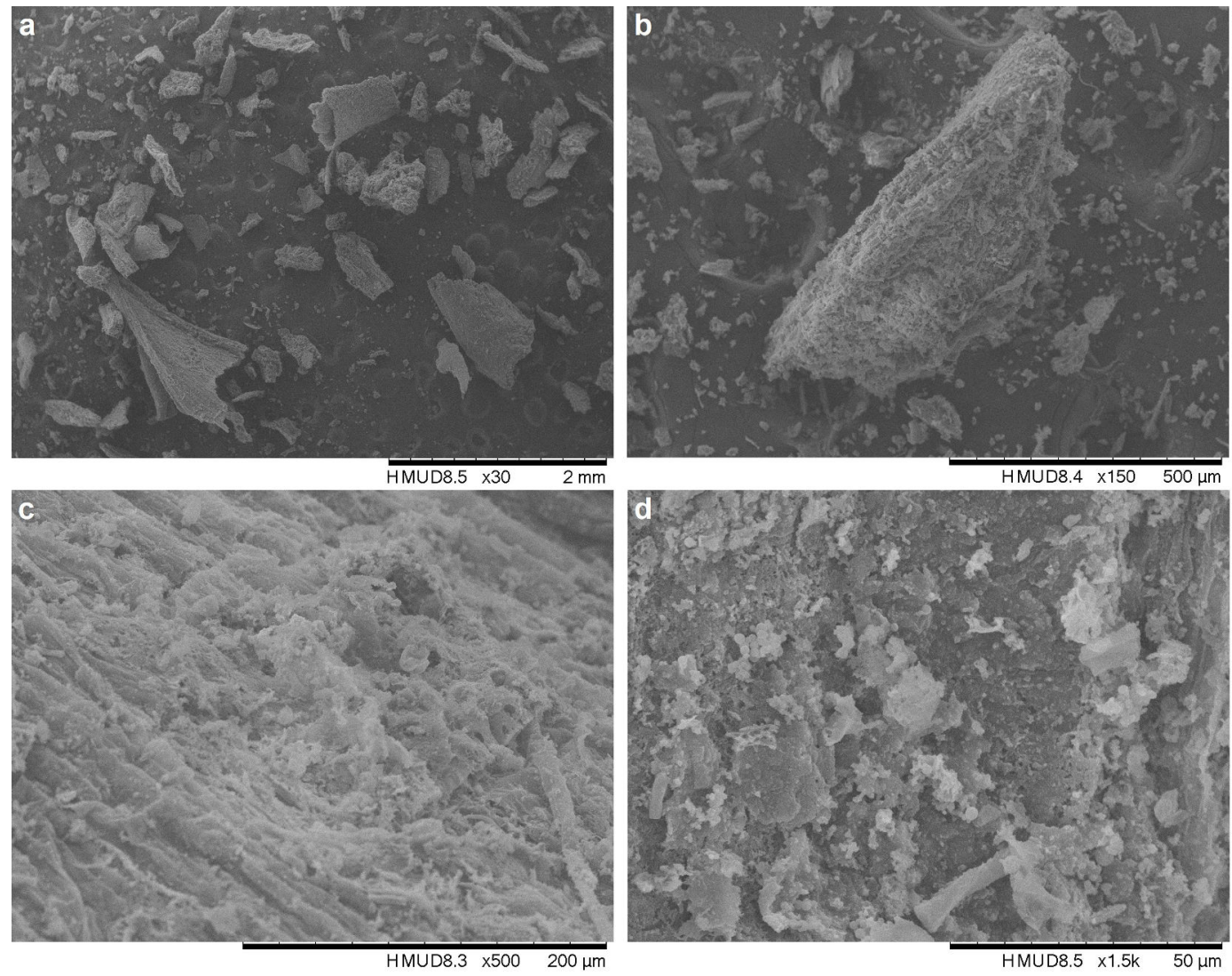

Figura 5.13: Visão do biocarvão no MEV. a: visão geral com apliação de 30x; b: partículas com ampliação de 150x; c: estruturas com ampliação de 500x; d: micro estruturas com ampliação de 1500x

Percebe-se uma clara diferença em relação as imagens obtidas da biomassa: o biocarvão apresentou particulados maiores. Isto possivelmente ocorreu pois durante a HTL, moléculas voláteis formaram o bio-óleo e os demais produtos, já algumas partículas de baixo peso molecular se juntam formando moléculas mais complexas, responsáveis também pelo aumento do poder calorífico do biocarvão. Devido a essa união, também é possível observar a ausência de poros e uma estrutura muito mais rugosa e complexa do que a biomassa antes do processo térmico.

Na imagem (d) também é possível observar pequenos aglomerados esféricos, podendo indicar impurezas, que foram detectadas pelo sistema EDS.

O EDS indicou a presença de potássio, enxofre e alumíneo. Potássio pode ser relacionado novamente aos fertilizantes. Enxofre, apesar do baixo teor detectado, indica um contaminante presente em alguma fase do processo, possivelmente na utilização de algum material ou vidraria contaminada. Alumíneo, 
pode ser atribuído ao porta amostra utilizado, o qual é composto por este elemento.

\subsection{7}

\section{Cromatografia gasosa}

A análise por CG foi realizada com o objetivo de determinar os principais compostos químicos presentes no bio-óleo obtido após a HTL. A Figura 5.14 representa o cromatograma obtido.

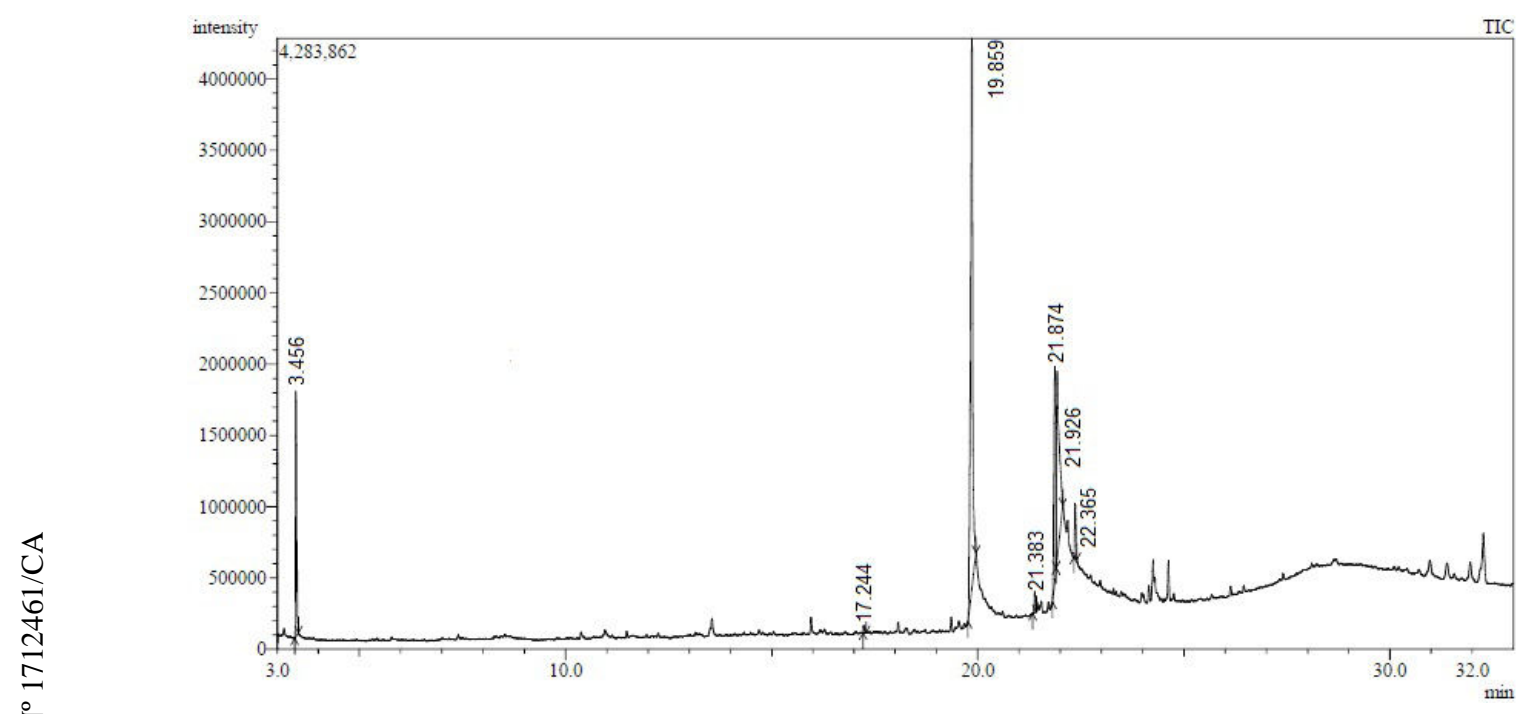

Figura 5.14: Cromatografia gasosa do bio-óleo

Cada tempo de residência representa o tempo total para o composto passar pela coluna cromatográfica, este tempo varia de acordo com as interações entre composto e coluna. Já a intensidade do sinal é obtida pela emissão de íons e detectada através do espectrômetro de massas. Assim, comparando ambos os resultados com referências de bibliotecas do equipamento, é possível determinar cada componente do bio-óleo.

É possível observar diversos picos, no entanto, cada componente apresenta um grau de similaridade com a biblioteca utilizada. Quanto maior o grau de similaridade, maior a probabilidade do componente ser determinado de forma correta. Desta forma, apenas os componentes com alto grau de certeza foram identificados, como representado na Tabela 5.14. 
Tabela 5.14: Principais compostos identificados por CG

\begin{tabular}{ccc}
$\begin{array}{c}\text { Pico } \\
(\min )\end{array}$ & $\begin{array}{c}\text { Composto e } \\
\text { estrutura }\end{array}$ & $\begin{array}{c}\text { Grau de } \\
\text { similaridade (\%) }\end{array}$ \\
\hline
\end{tabular}

Metil éster, ácido linoleico

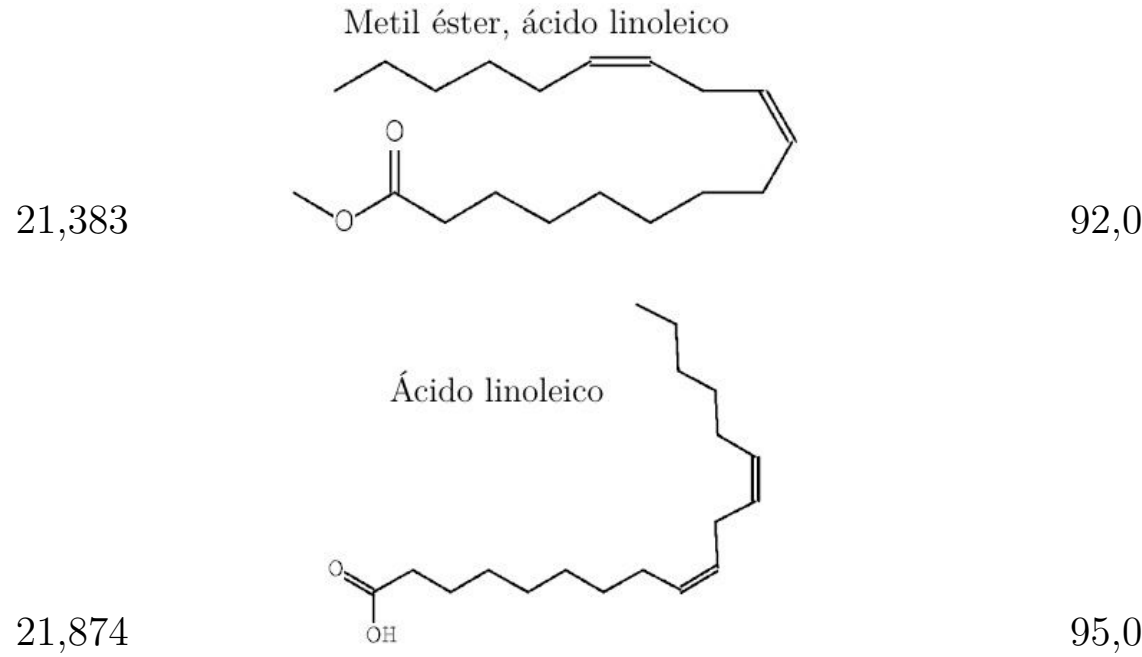

21,926

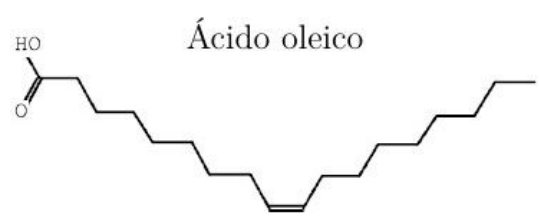

93,0

22,365

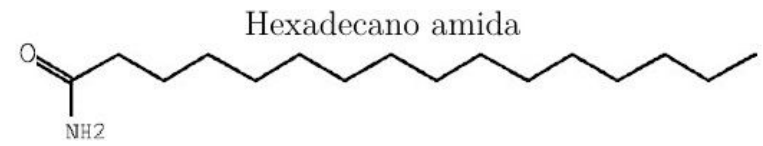

93,0

O primeiro composto é uma cetona, provavelmente formada a partir da acetona residual usada na extração soxhlet. O ácido pentadecanóico é uma variação do ácido palmítico, obtido com a quebra de uma ligação sigma entre os dois últimos carbonos da cadeia. Da mesma forma, o metil éster, ácido linoleico é uma variação do ácido linoleico, formado pela adição de um novo carbono 
a cadeia. A amida formada pode ser atribuída a combinação do nitrogênio, presente na biomassa, com ácido palmítico.

O ácido palmítico, linoleico e oleico são alguns dos ácidos graxos mais comuns encontrados em espécies vegetais, importantes na construção da parede celular. Além disso, esses ácidos são alguns dos mais utilizados para a produção de biocombustíveis. Através da reação de esterificação na presença de um álcool, ocorrerá a formação de um éster de ácido graxo que posteriormente formará o biodiesel [80].

Após a realização de uma HTL com biomassa de madeira, Nazari et al. (2015) identificaram uma cetona equivalente, ácido palmítico e o metil éster, ácido linoleico [59]. Já Zhou et al. (2010), identificaram após a HTL de algas, os mesmos componentes, além de ácido oleico e uma amida equivalente [47].

Através do resultado do CG foi possível identificar os ácidos graxos precursores do biodiesel. Assim, o valor do PCS obtido anteriormente, 16,4\% inferior ao biodiesel tradicional, pode ser explicado uma vez que os ácidos graxos ainda não sofreram a esterificação para a formação dos ésteres de biodiesel. 


\section{6 \\ Conclusões}

A caracterização inicial do bagaço de malte indicou tamanho de partícula pequeno, inferior a $2,5 \mathrm{~mm}$, presença de compostos lignocelulósicos e alto teor de umidade, acima de $91 \%$, sendo assim uma biomassa ideal para o processo de liquefação hidrotérmica, uma vez que a água presente é fundamental para as reações de quebra e recombinação das moléculas.

A modelagem cinética da primeira etapa da HTL, onde os reagentes se transformam em produtos liquefeitos, apresentou $62,08 \mathrm{~kJ} \cdot \mathrm{mol}^{-1}$ de energia de ativação e 2,88 de média da ordem aparente da reação, indicando que a liquefação envolve diversas outras reações simultâneas complexas.

Através da Teoria do Estado de Transição foi possível relacionar os resultados cinéticos com a termodinâmica, obtendo valores médios de $\Delta G^{*}, \Delta H^{*}$ e $\Delta S^{*}$ de $131,43 \mathrm{~kJ} . \mathrm{mol}^{-1}, 55,04 \mathrm{~kJ} . \mathrm{mol}^{-1}$ e $180,49 \mathrm{~J} . \mathrm{mol}^{-1} \cdot \mathrm{K}^{-1}$ respectivamente para a reação em fase gasosa, comprovando pouca diferença para a reação ocorrendo em solução

Com a metodologia adotada para a HTL foi possível obter bio-óleo, biocarvão, produtos líquidos e gasosos. Observou-se que no tempo de 30 minutos ocorre a produção máxima de bio-óleo, enquanto no biocarvão o tempo foi variado. No entanto, levando-se em conta a produtividade (rendimento por minutos de processo), identificou-se que em 5 minutos a produtividade é máxima para todos os casos, sendo este o tempo ótimo de residência.

Pela análise do poder calorífico superior, comprovou-se que o aumento da temperatura do processo gera bio-óleo e biocarvão com maiores PCS, concluíndo que a temperatura ideal é $300{ }^{\circ} \mathrm{C}$. Em 5 min e a $300{ }^{\circ} \mathrm{C}$, melhores condições de operação, a HTL gerou um bio-óleo com rendimento de 17,7\% e PCS de 33,6 MJ.kg ${ }^{-1}$, sendo 27,8\% inferior a gasolina e um biocarvão com 14,6\% de rendimento e PCS de $26,7 \mathrm{MJ} \cdot \mathrm{kg}^{-1}$, sendo $11,4 \%$ superior ao carvão tradicional

Através das caracterizações e comparações da biomassa inicial com o biocarvão produzido, foi percebida uma grande diferença. Material volátil da biomassa foi consumido no processo, gerando um biocarvão com grande quantidade de carbono fixo, como observado na análise imediata, análise elementar e termogravimetria. O TG também indicou que grande parte da 
celulose e principalmente a hemicelulose foram consumidas na HTL, resultando em picos de perda de massa pequenos, para o biocarvão, nos intervalos de decomposição desses materiais.

A espectroscopia no infravermelho reforçou que a composição dos materiais são diferentes, indicando espectros de absorção distintos. A análise por microscopia eletrônica de varredura também demonstrou diferenças na morfologia dos materiais, sendo observado uma biomassa com particulas menores e um biocarvão com particulados grandes e mais rugosos, indicando moléculas mais complexas.

A cromatografia gasosa do bio-óleo indicou a presença de ácidos graxos muito comuns em biomassas vegetais, que são precursores na produção de biodiesel. O PCS do bio-óleo poderia ser aumentado após reações de esterificação dos ácidos presentes.

Pelos resultados obtidos, concluiu-se que a liquefação hidrotérmica é uma alternativa eficiente para a utilização de resíduos de biomassa, visando a produção de biocombustíveis renováveis. Dessa forma, os produtos gerados a partir do bagaço de malte poderiam ser reaproveitados para gerar parte da energia utilizada na indústria cervejeira. 


\section{7 \\ Recomendações}

Nesta dissertação foram estudadas algumas condições de operação do processo de liquefação hidrotérmica, bem como as caracterizações dos produtos formados. Algumas sugestões para trabalhos futuros seguindo esta linha de pesquisa são:

$\triangleright$ Alterar variáveis processo, como tipo de bagaço de malte, temperatura, tempo de residência, atmosfera reacional e proporção biomassa/água.

$\triangleright$ Produzir e utilizar aditivos que possibilitem um aumento de rendimento dos produtos.

$\triangleright$ Separar e caracterizar os produtos líquidos e gasosos que também são gerados na HTL e identificar possíveis destinações viáveis.

$\triangleright$ Realizar as reações de esterificação usando o bio-óleo com a finalidade de produzir ésteres com maior poder calorífico superior, equivalentes ao biodiesel.

$\triangleright$ Realizar uma análise econômica da implementação do sistema de HTL em escala industrial em uma cervejaria. 


\section{Referências bibliográficas}

[1] HÖÖK, M.; TANG, X.. Depletion of fossil fuels; anthropogenic climate change - A review. Energy Policy, 52:797-809, 2013.

[2] ENERGY INFORMATION ADMINISTRATION (US) AND GOVERNMENT PUBLICATIONS OFFICE. International Energy Outlook 2016: With Projections to 2040. Government Printing Office, 2016.

[3] KÅBERGER, T.. Progress of renewable electricity replacing fossil fuels. Global Energy Interconnection, 1(1):48-52, 2018.

[4] BARBOSA, R. M.. Contribuição dos créditos de carbono na viabilidade de projetos de eficiência energética térmica e de troca de combustíveis em cervejarias. Dissertação de mestrado, USP, São Paulo, 2010.

[5] DEMIRBAS, A.. Biofuels sources, biofuel policy, biofuel economy and global biofuel projections. Energy conversion and management, 49(8):2106-2116, 2008.

[6] ALAUDDIN, Z. A. B. Z.; LAHIJANI, P.; MOHAMMADI, M.; MOHAMED, A. R.. Gasification of lignocellulosic biomass in fluidized beds for renewable energy development: A review. Renewable and Sustainable Energy Reviews, 14(9):2852-2862, 2010.

[7] LURDETE, E.. Número de cervejarias no Brasil aumenta $750 \%$ em 10 anos. Forbes Brasil, 2018. Acesso em: Novembro de 2018, disponível em: <https://forbes.uol.com.br/colunas/2018/01/numero-de-cervejarias-nobrasil-aumenta-750-em-10-anos/>.

[8] CERVIERI, J. O.. Panoramas setoriais 2030: bebidas. Banco Nacional de Desenvolvimento Econômico e Social, 2017.

[9] SANTOS, M. S.; RIBEIRO, F. M.. Cervejas e Refrigerantes. CETESB - Companhia de Tecnologia de Saneamento Ambiental, 2005.

[10] DE OLIVEIRA, C. F. D.; VENDRUSCOLO, F.; DA COSTA, J. P. V.; DE ARAÚJO, W. D. B.. Bagaço de malte como substrato para produção 
de biopigmentos produzidos por Monascus ruber CCT 3802. Revista de Agricultura Neotropical, 3(3):6-9, 2016.

[11] MATHIAS, T.; MELLO, P.P.M.; SERVULO, E.. Caracterização de resíduos cervejeiros. Blucher Chemical Engineering Proceedings, 1(2):38053812, 2015.

[12] AKHTAR, J.; AMIN, N. A. S.. A review on process conditions for optimum bio-oil yield in hydrothermal liquefaction of biomass. Renewable and Sustainable Energy Reviews, 15(3):1615-1624, 2011.

[13] TOOR, S. S.; ROSENDAHL, L.; RUDOLF, A.. Hydrothermal liquefaction of biomass: a review of subcritical water technologies. Energy, 36(5):2328-2342, 2011.

[14] INTERNATIONAL ENERGY AGENCY. Global Energy and CO2 Status Report 2017. report, 2018. Acesso em novembro de 2018, disponível em: $<$ www.iea.org/publications/freepublications/publication/GECO2017.pdf > .

[15] EMPRESA DE PESQUISA ENERGÉTICA. Balanço Energético Nacional. report, 2018. Acesso em novembro de 2018, disponível em: <http://epe.gov.br/sites-pt/publicacoes-dadosabertos/publicacoes/PublicacoesArquivos/publicacao-303/topico419/BEN2018.pdf $>$.

[16] UNION, E.. Directive 2009/28/EC of the European Parliament and of the Council of 23 April 2009 on the promotion of the use of energy from renewable sources and amending and subsequently repealing Directives 2001/77/EC and 2003/30/EC. Official Journal of the European Union, 5:2009, 2009.

[17] GOMES, C. F. S.; MAIA, A. C. C.. Using multicriteria decision support in a biomass alternatives ordination problem. Production, 23(3):488-499, 2013.

[18] FANTINI, M. Biomass Availability, Potential and Characteristics. In: BIOREFINERIES, p. 21-54. Springer, 2017.

[19] BASU, P.. Biomass gasification and pyrolysis: practical design and theory. Academic press, 2010.

[20] MOHAN, D.; PITTMAN, C. U.; STEELE, P. H.. Pyrolysis of wood/biomass for bio-oil: a critical review. Energy \& fuels, 20(3):848-889, 2006. 
[21] SANTOS, F. A.; QUEIRÓZ, J. H. D.; COLODETTE, J. L.; FERNANDES, S. A.; GUIMARÃES, V. M.; REZENDE, S. T.. Potencial da palha de canade-açúcar para produção de etanol. Química Nova, 35(5):1004-1010, 2012.

[22] RABELO, S. C.; ET AL.. Avaliação de desempenho do prétratamento com peróxido de hidrogênio alcalino para a hidrólise enzimática de bagaço de cana-de-açúcar. 2007. Dissertação de mestrado, Unicamp, Campinas, julho de 2007.

[23] HABIBI, Y.; LUCIA, L. A.; ROJAS, O. J.. Cellulose nanocrystals: chemistry, self-assembly, and applications. Chemical reviews, 110(6):3479-3500, 2010.

[24] KLASS, D. L.. Biomass for renewable energy, fuels, and chemicals. Elsevier, 1998.

[25] SCHENA, T.. Pirólise da fibra da casca de coco: caracterização do bio-óleo antes e após a aplicação de dois processos de melhoramento. 2015. Dissertação de mestrado, UFRGS, Porto Alegre, janeiro de 2015.

[26] LLORENTE, M. J. F.; CUADRADO, R. E.. Influence of the amount of bed material on the distribution of biomass inorganic elements in a bubbling fluidised bed combustion pilot plant. Fuel, 86(56):867-876, 2007.

[27] CASAgRANDE, M. C.; SARTOR, M. N.; GOMES, V.; DELLA, V. P.; HOTZA, D.; OLIVEIRA, A. P. N.. Reaproveitamento de resíduos sólidos industriais: processamento e aplicações no setor cerâmico. Cerâmica Industrial, 13(1/2):34-42, 2008.

[28] PEREIRA, D. A.; ET AL.. Gestão e tratamento dos resíduos sólidos industriais na região sul do estado do Rio de Janeiro. 2008. Dissertação de mestrado, FEUP, Porto, 2008.

[29] PARADELA, F.. Estudo da pirólise de misturas de resíduos plásticos e de biomassa. 2007. Dissertação de mestrado, UNL, Lisboa, 2007.

[30] BRASIL. Decreto no 2314, de 04 de setembro de 1997. Diário Oficial da Republica Federativa do Brasil, 1997. Acesso em novembro de 2018, disponível em: <http://www.agricultura.gov.br/assuntos/vigilanciaagropecuaria/ivegetal/bebidas-arquivos/decreto-no-2-314-de-4-de-setembrode-1997.doc/view $>$. 
[31] MEGA, J. F.;NEVES, E.; ANDRADE, C. J.. A produção de cerveja no Brasil. Revista Citino, 1(1):34-42, 2011.

[32] TSCHOPE, E. C.. Microcervejarias e cervejarias: a história, a arte e a tecnologia. São Paulo: Aden, p. 223, 2001.

[33] PALMER, J. J.. How to Brew: Everything You Need to Know to Brew Great Beer Every Time. NATL BOOK NETWORK, 2006.

[34] VENTURINI, W. G. F.. Bebidas alcoólicas: ciência e tecnologia. Editora Blucher, 2018.

[35] BORTOLI, D. A. S.; DOS SANTOS, F.; STOCCO, N. M.; ORELLI JR, A. A.; TON, A.; NEME, F. F.; DO NASCIMENTO, D. D.. Leveduras e produção de cervejas-Revisão. Bioenergia em Revista: Diálogos (ISSN: 2236-9171), 3(1):45-58, 2013.

[36] KUNZE, W.. Brewing \& Malting. VLB Berlin, 2004. 3rd International Edition, 2004.

[37] BATISTA, M. C. T.. Produção de dextranases a partir de bagaço de malte: caracterização e avaliação do pontencial de aplicação em indústria sucroalcooleira. 2014. Tese de doutorado, UFPR, Curitiba, 2014.

[38] GERON, L.J.V.; ZEOULA, L.M.. Silagem do resíduo úmido de cervejaria: uma alternativa na alimentação de vacas leiteiras. Pubvet, 1(8):1982-1263, 2007.

[39] DEMIRBAS, A.. Biorefineries: current activities and future developments. Energy Conversion and Management, 50(11):2782-2801, 2009.

[40] ZHONG, C.; WEI, X.. A comparative experimental study on the liquefaction of wood. Energy, 29(11):1731-1741, 2004.

[41] YIN, S.; DOLAN, R.; HARRIS, M.; TAN, Z.. Subcritical hydrothermal liquefaction of cattle manure to bio-oil: effects of conversion parameters on bio-oil yield and characterization of bio-oil. Bioresource Technology, 101(10):3657-3664, 2010.

[42] ZHANG, B.; VON KEITZ, M.; VALENTAS, K.. Thermochemical liquefaction of high-diversity grassland perennials. Journal of Analytical and Applied Pyrolysis, 84(1):18-24, 2009. 
[43] COUTO, E. A.. Produção de biomassa em lagoas de alta taxa com diferentes profundidades e seu aproveitamento para geração de energia via liquefação hidrotérmica. 2016. Tese de doutorado, UFV, Viçosa, 2016.

[44] DÉNIEL, M.; HAARLEMMER, G.; ROUBAUD, A.; WEISS-HORTALA, E.; FAGES, J.. Energy valorisation of food processing residues and model compounds by hydrothermal liquefaction. Renewable and Sustainable Energy Reviews, 54:1632-1652, 2016.

[45] KARAGÖZ, S.; BHASKAR, T.; MUTO, A.; SAKATA, Y.. Hydrothermal upgrading of biomass: Effect of $\mathrm{K} 2 \mathrm{CO} 3$ concentration and biomass/water ratio on products distribution. Bioresource technology, 97(1):90-98, 2006.

[46] SINGH, R.; BALAGURUMURTHY, B.; BHASKAR, T.. Hydrothermal liquefaction of macro algae: effect of feedstock composition. Fuel, 146:69-74, 2015.

[47] ZHOU, D.; ZHANG, L.; ZHANG, S.; FU, H.; CHEN, J.. Hydrothermal liquefaction of macroalgae Enteromorpha prolifera to bio-oil. Energy \& Fuels, 24(7):4054-4061, 2010.

[48] SUGANO, M.; TAKAGI, H.; HIRANO, K.; MASHIMO, K.. Hydrothermal liquefaction of plantation biomass with two kinds of wastewater from paper industry. Journal of Materials Science, 43(7):2476-2486, 2008.

[49] SANTOS, C. J. R.. Termoliquefação da torta da extração do óleo de girassol em alta pressão para a produção de bio-óleo. 2014. Dissertação de mestrado, UNIT, Aracajú, 2014.

[50] BROWN, T. M.; DUAN, P.; SAVAGE, P. E.. Hydrothermal liquefaction and gasification of Nannochloropsis sp. Energy \& Fuels, 24(6):36393646, 2010.

[51] BOUNDY, R. G.; DIEGEL, S. W.; WRIGHT, L. L.; DAVIS, S. C.. Biomass Energy Data Book: Edition 4. Technical report, Oak Ridge National Laboratory (ORNL), 2011.

[52] CHEN, W.; ZHANG, Y.; ZHANG, J.; YU, G.; SCHIDEMAN, L. C.; ZHANG, P.; MINARICK, M.. Hydrothermal liquefaction of mixed-culture algal biomass from wastewater treatment system into bio-crude oil. Bioresource technology, 152:130-139, 2014. 
[53] PASQUINI, D.; PIMENTA, M. T. B.; FERREIRA, L. H.; CURVELO, A. A. S.. Sugar cane bagasse pulping using supercritical CO2 associated with co-solvent 1-butanol/water. The Journal of supercritical fluids, 34(2):125-131, 2005.

[54] BRAND, S.; HARDI, F.; KIM, J.; SUH, D. J.. Effect of heating rate on biomass liquefaction: differences between subcritical water and supercritical ethanol. Energy, 68:420-427, 2014.

[55] YAN, Y.; HU, M.; WANG, Z.. Kinetic study on the liquefaction of cornstalk in polyhydric alcohols. Industrial crops and products, 32(3):349-352, 2010.

[56] BALL, D. W.. Physical Chemistry. Copyright, 2011. chapter: 20 Kinetics, 2011.

[57] TRUHLAR, D. G.; GARRETT, B. C.; KLIPPENSTEIN, S. J.. Current status of transition-state theory. The Journal of physical chemistry, 100(31):12771-12800, 1996.

[58] LAIDLER, K. J.; KING, M. C.. Development of transition-state theory. The Journal of physical chemistry, 87(15):2657-2664, 1983.

[59] NAZARI, L; YUAN, Z.; SOUZANCHI, S.; RAY, M. B.; XU, C. C.. Нydrothermal liquefaction of woody biomass in hot-compressed water: catalyst screening and comprehensive characterization of bio-crude oils. Fuel, 162:74-83, 2015.

[60] DE PAULA PROTÁSIO, T.; ALVES, I. C. N.; TRUGILHO, P. F.; SILVA, V. O.; BALIZA, A. E. R.. Compactação de biomassa vegetal visando à produção de biocombustíveis sólidos. Pesquisa Florestal Brasileira, 31(68):273, 2011.

[61] ALMA, M. H.; ACEMIOGLU, B.. A kinetic study of sulfuric acidcatalyzed liquefaction of wood into phenol. Chemical Engineering Communications, 191(7):968-980, 2004.

[62] SU, C.; PULS, R. W.. Kinetics of trichloroethene reduction by zerovalent iron and tin: pretreatment effect, apparent activation energy, and intermediate products. Environmental Science \& Technology, 33(1):163-168, 1999.

[63] ACEMIOGLU, B.; ALMA, M. H.. Kinetics of wood phenolysis in the presence of $\mathrm{HCl}$ as catalyst. Journal of applied polymer science, 85(5):1098-1103, 2002. 
[64] ZHANG, H.; YANG, H.; GUO, H.; HUANG, C.; XIONG, L.; CHEN, X.. Kinetic study on the liquefaction of wood and its three cell wall component in polyhydric alcohols. Applied Energy, 113:1596-1600, 2014.

[65] TELMO, C.; LOUSADA, J.. The explained variation by lignin and extractive contents on higher heating value of wood. Biomass and bioenergy, 35(5):1663-1667, 2011.

[66] ENGASP - ENGENHARIA E TÉCNICAS AFINS LDA.. Estudo do potencial energético de calor de cada biomassa/resíduo agrícola e vegetal. Projeto N.34001. Lisbon, 2014.

[66] LINAN-MONTES, A.; DE LA PARRA-ARCINIEGA, S. M.; GARZAGONZÁLEZ, M. T.; GARCÍA-REYES, R. B.; SOTO-REGALADO, E.; CERINO-CÓRDOVA, F. J.. Characterization and thermal analysis of agave bagasse and malt spent grain. Journal of Thermal Analysis and Calorimetry, 115(1):751-758, 2014.

[67] LIU, Z.; QUEK, A.; HOEKMAN, S. K.; BALASUBRAMANIAN, R.. Production of solid biochar fuel from waste biomass by hydrothermal carbonization. Fuel, 103:943-949, 2013.

[68] TSAI, W. T.; LEE, M. K.; CHANG, Y. M.. Fast pyrolysis of rice straw, sugarcane bagasse and coconut shell in an induction-heating reactor. Journal of analytical and applied pyrolysis, 76(1-2):230-237, 2006.

[69] MULLEN, C. A.; BOATENG, A. A.; GOLDBERG, N. M.; LIMA, I. M.; LAIRD, D. A.; HICKS, K. B.. Bio-oil and bio-char production from corn cobs and stover by fast pyrolysis. Biomass and bioenergy, 34(1):67-74, 2010.

[70] BILLER, P.; ROSS, A. B.. Potential yields and properties of oil from the hydrothermal liquefaction of microalgae with different biochemical content. Bioresource technology, 102(1):215-225, 2011.

[71] CHUMPOO, J.; PRASASSARAKICH, P.. Bio-oil from hydroliquefaction of bagasse in supercritical ethanol. Energy \& Fuels, 24(3):2071-2077, 2010.

[72] VIEIRA, A. C.. Caracterização da biomassa proveniente de resíduos agrícolas. 2012. Dissertação de mestrado, Unioeste, Cascavel, 2012.

[73] TEIXEIRA, V. A.; MARQUES, M. R.; SIQUEIRA, A. M. R.; SIQUEIRA, D. V. F.. Potencial energético da biomassa e carvão vegetal do 
epicarpo e da torta de pinhão manso (Jatropha curcas). Cerne, 17(2):267-273, 2011.

[74] ELMOUWAHIDI, A.; VIVO-VILCHES, J. F.; PÉREZ-CADENAS, A. F.; MALDONADO-HÓDAR, F. J.; CARRASCO-MARÍN, F.. Free metal oxygen-reduction electro-catalysts obtained from biomass residue of the olive oil industry. Chemical Engineering Journal, 306:11091115, 2016.

[75] RAMOS, P. H.; GUERREIRO, M. C.; RESENDE, E. C.; GONÇALVES, M.. Produção e caracterização de carvão ativado produzido a partir do defeito preto, verde, ardido (PVA) do café. Química nova, 32(5):1139-1143, 2009.

[76] DE PAULA PROTÁSIO, T.; BUfALINO, L.; TONOLI, G. H. D.; COUTO, A. M.; TRUGILHO, P. F.; JÚNIOR, M. G.. Relação entre o poder calorífico superior e os componentes elementares e minerais da biomassa vegetal. Pesquisa Florestal Brasileira, 31(66):113, 2011.

[77] SILVERSTEIN, R. M.; WEBSTER, F.X.; KIEMLE, D.J.. Spectrometric identification of organic compounds. Copyright. 7th edition, United States of America, 2005.

[78] SHUPING, Z.; YULONG, W.; MINGDE, Y.; KALEEM, I.; CHUN, L.; TONG, J.. Production and characterization of bio-oil from hydrothermal liquefaction of microalgae Dunaliella tertiolecta cake. Energy, 35(12):5406-5411, 2010.

[79] CORRADI, B. A.; MACEDO, A.; TRUGILHO, P.; NOGUEIRA, I.; COSTA, A.. Estudo da degradação térmica da madeira de Eucalyptus através de termogravimetria e calorimetria. Revista Árvore, 37(3), 2013.

[80] RAMOS, M. J.; FERNÁNDEZ, C. M.; CASAS, A.; RODRÍGUEZ, L.; PÉREZ, Á.. Influence of fatty acid composition of raw materials on biodiesel properties. Bioresource technology, 100(1):261-268, 2009. 